\title{
Antioxidant activity of oat bran hydrolyzed proteins in vitro and in vivo
}

\author{
by
}

Sara Jodayree

A thesis submitted to the Faculty of Graduate and Postdoctoral Affairs in partial fulfillment of the requirements for the degree of

Doctor of Philosophy in Chemistry

Concentration in

Food Science and Nutrition

Carleton University

Ottawa, Ontario

C) 2014, Sara Jodayree 


\section{Abstract}

Oats contain molecules with well-known health benefits. Its fibers are used in different preparations to improve gastro-intestinal health and to reduce blood cholesterol. Avenanthramides, a group of phenolic antioxidants only present in oats have been demonstrated to be bioavailable in animals and humans. In recent years, proteins from foods have been viewed as not just sources of essential amino acids but also as sources of biologically active peptides (e.g. antioxidant, antihypertensive, antitumor). Antioxidant activities have been reported for hydrolyzed proteins from wheat, rice and corn byproducts but not for those from oats. The objective of this thesis was to investigate the antioxidant properties of hydrolyzed oat proteins in three different conditions (in vitro and in vivo). The first part of this thesis focusses on the activity of proteins extracted in the presence of salt and digested with trypsin (TPH) and alcalase (APH). The digests TPH and APH were ultra-filtered using $2 \mathrm{kDa}$, and $10 \mathrm{kDa}$ molecular cutoff membranes. The radical scavenging properties were determined by 2,2-diphenyl-1-picrylhydrazyl (DPPH) and oxygen radical absorbance assay (ORAC). It was found that APH 2kDa was the strongest inhibitor (35\%) of DPPH radicals and also TPH had a better peroxyl radical scavenging activity (ORAC) $434 \pm 16 \mu$ mol trolox equivalents (TE)/g) compared to APH $(269 \pm 4 \mu \mathrm{mol} \mathrm{TE} / \mathrm{g})$ and $\mathrm{TPH}>2 \mathrm{kDa}(345 \pm 15 \mu \mathrm{mol} \mathrm{TE} / \mathrm{g})$. In the metal chelating assay, trypsin digest (TPH) better chelated $\mathrm{Fe}^{2+}$ ions compared to $\mathrm{APH}$ and other fractions. The inhibition of linoleic acid autoxidation, showed that both trypsin and alcalase digests equally lowered the formation of lipid peroxides after five days of incubation. It appeared that trypsin hydrolysate and its $\leq 2 \mathrm{kDa}$ fraction possessed the strongest activities and may have application in food products. 
The second part of this thesis, demonstrated that pre-treatment of oat bran with four carbohydrases (viscozyme ${ }^{\circledR}$ L, alpha-amylase, amyloglucosidase, and celluclast ${ }^{\circledR}$ ) at different concentrations resulted in greater protein extraction up to $82 \%$ compared to $54 \%$ for control bran not treated with carbohydrases. All protein isolates were hydrolyzed with alcalase and evaluated for antioxidant activities. All brans treated with carbohydrases had higher peroxyl radical scavenging activities compared to the control. The sequences of four potential active peptides were identified by tandem mass spectrometry.

The final part of this thesis research evaluated the potential of oat protein hydrolyzed $(\mathrm{OPH})$ with trypsin (better in vitro antioxidant activity relative to alcalase hydrolysate) to reduce oxidative stress in vivo. Three different concentrations $(1,10$, and $100 \mathrm{mg} \mathrm{OPH} / \mathrm{g}$ diet) were added to the diet of CD-1 male mice. The animals were divided into five groups, normal diet (ND), high fat (HF), and HF containing 1, 10, and $100 \mathrm{mg} \mathrm{OPH/g}$. The study lasted for seven weeks in total, four weeks on normal diet and three weeks on the experimental diet and after mice were sacrificed. Red blood cells, liver, brain, muscle, lung, and heart tissues were collected for analysis. Erythrocytes of mice on 100 mg OPH/g had higher $(\mathrm{p}<0.05)$ peroxyl radical scavenging activity compared to HF group. The activity of the antioxidant enzyme superoxide dismutase (SOD) in the liver of mice on HF diet was $13.2 \%$ lower compared to the activity of those on the normal diet. Advanced oxidation protein products (AOPP) level in the brain and heart of animals supplemented with $10 \mathrm{mg} \mathrm{OPH} / \mathrm{g}$ was lowered significantly compared to the rest of the groups. Supplementation with OPH increased $(\mathrm{p}<0.05)$ vitamin $\mathrm{C}$ level but did not affect vitamin A or E concentrations in the liver. In conclusion, addition of OPH to high 
fat diet reduced oxidative stress by either increasing the total antioxidative capacity of erythrocytes, reducing protein oxidation or nitric oxide depending on the organ. From these results, it appears that $\mathrm{OPH}$ can be beneficial in conditions associated with oxidative stress. 


\section{Acknowledgements}

I am very grateful to have an opportunity to do my Ph.D. under the supervision of Professor Apollinaire Tsopmo. I appreciate his guidance and continuous support.

Also I would like to thank my family and friends, who supported me throughout my

Ph.D, this task would have not been possible without the support from my supervisor Dr.

Tsopmo, my professors, specially Dr. Robert C. Burk, Dr. Sean Barry, Dr. Farah

Hosseinian as well as my family and friends. I thank my committee members, Professors

Alfonso Abizaid, Illimar Altosaar, Farah Hosseinian, and Chantal Matar, for their helpful suggestions and comments. Every single person contributed to help me achieve my goal.

Dr. Tsopmo, showed me the road and helped me get started on the path of my degree, his encouragement, and faith in me throughout have been extremely helpful.

I would also like to thank Chantelle Gravelle and Marilyn Stock for their kindness and administrative assistance.

Thank you Mom and Dad, for being encouraging and giving support when I needed it. All my friends and relatives have supported me in their own ways.

Finally, I dedicate this thesis to my family with special thanks. Thank you for your understanding, giving me the strength to hold on to my ideas, encouraging me to pursue my dreams, and for always giving me support when I needed it 


\section{List of Publications}

This thesis is based on the following original publications.

Jodayree, S., Patterson, Z.R., MacKay, H., Abizaid, A.B., Tsopmo, A. 2014. Blood and liver antioxidant capacity of mice fed high fat diet supplemented with digested oat bran proteins. Inter. J. Food. Sci. Nutr. Eng. 4: 9-14.

Jodayree, S., Smith, J.C., and Tsopmo. A. 2012. Use of carbohydrase to enhance protein extraction efficiency and antioxidative properties of oat bran protein hydrolysates. Food Res. Int. 46(1): 69-75.

Tsopmo, A., Cooper, A., and Jodayree, S. 2010. Enzymatic hydrolysis of oat flour protein isolates to enhance antioxidative properties. Int J Food Sci Technol 2(4): 206-212. 


\section{Table of Contents}

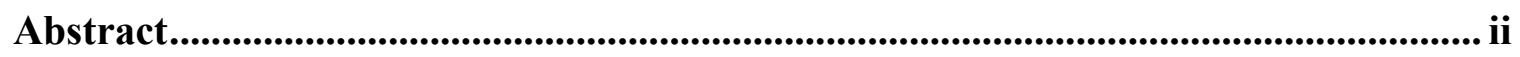

List of Publications ................................................................................................... vi

Table of Contents .................................................................................................... vii

List of Figures........................................................................................................................... xi

List of Tables .............................................................................................................................. xiv

Abbreviations .......................................................................................................................... Xv

Chapter 1 ....................................................................................................................................... 1

Background information .................................................................................................. 1

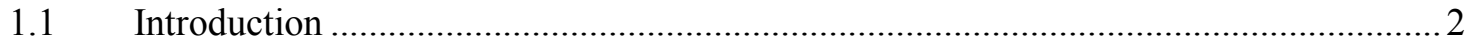

1.2 Chemical compounds in oats .............................................................................

1.2.1 Polysaccharides or carbohydrates ....................................................................

1.2.2 Phenol compounds in oats..................................................................................

1.2 .3 Proteins

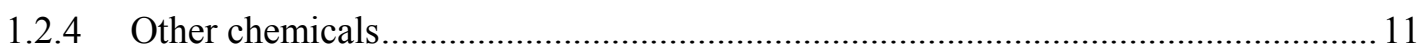

$1.3 \quad$ Bioactivity of oat compounds............................................................................11

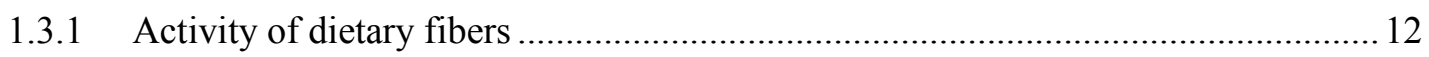

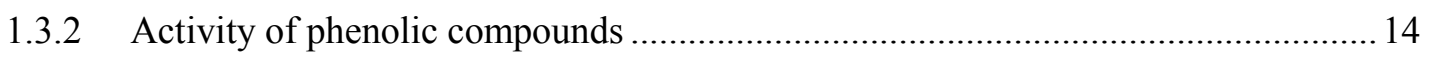

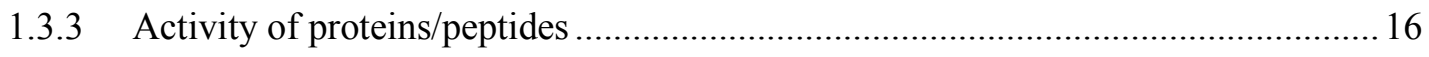

$1.4 \quad$ Methods for extraction of proteins ...................................................................... 18

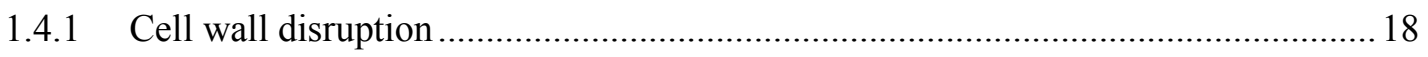

1.4.2 Solubilisation of proteins ……………………………………………………..... 19

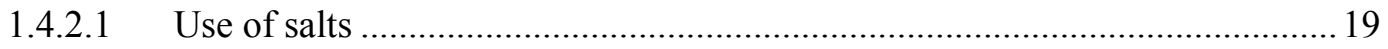

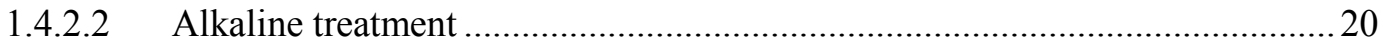




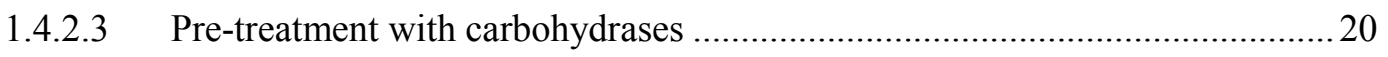

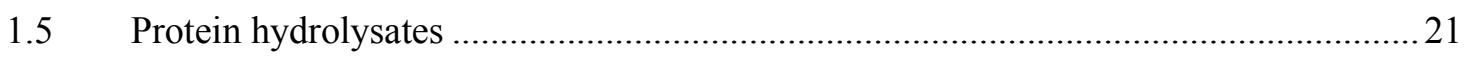

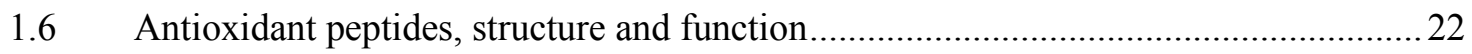

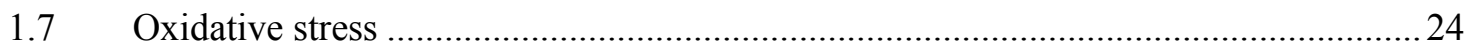

1.7.1 Reactive oxygen species and reactive nitrogen species ........................................2

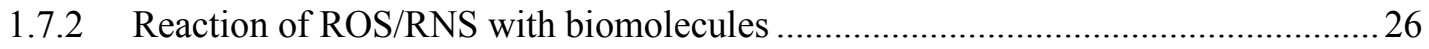

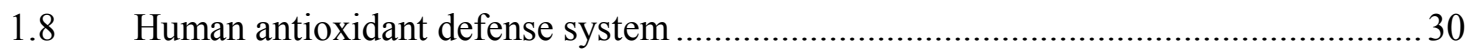

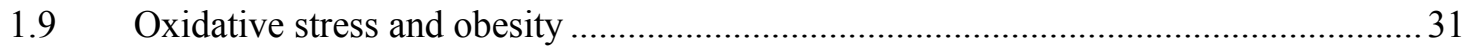

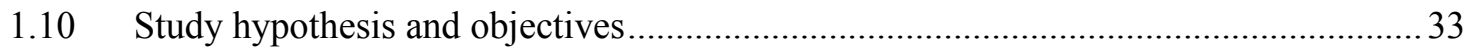

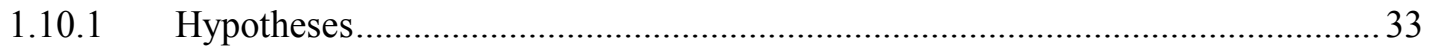

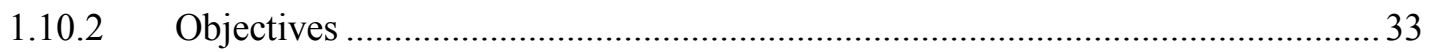

Chapter 2 ........................................................................................................................................... 34

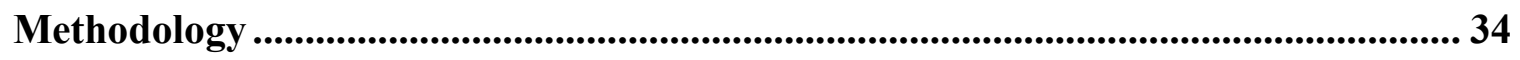

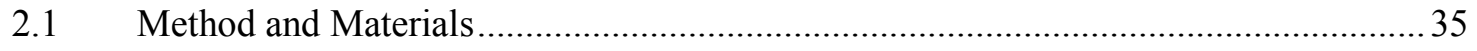

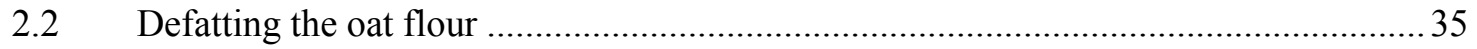

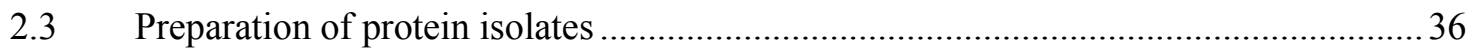

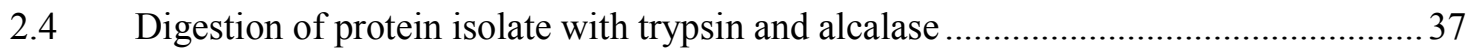

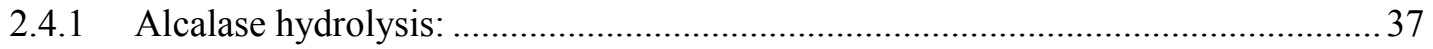

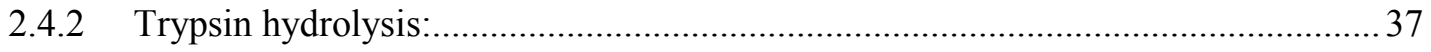

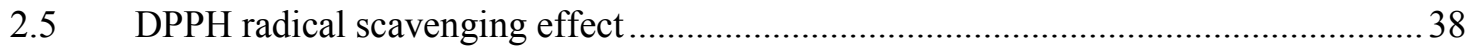

2.6 Oxygen radical absorbance assay of digested oat flour proteins ..................................39

2.7 Measurement of ferrous ion-chelating activity ..................................................... 39

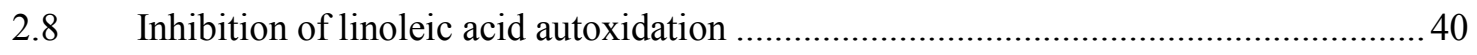

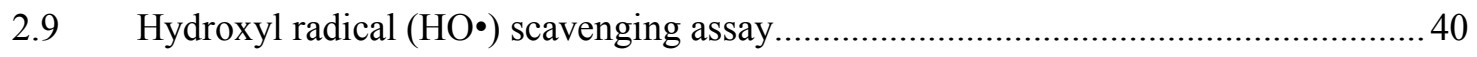

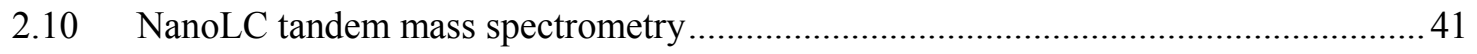

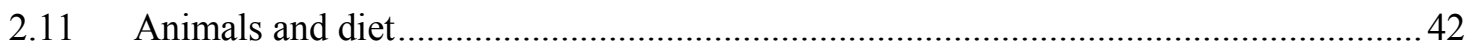




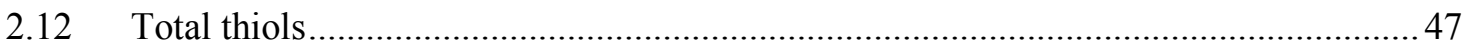

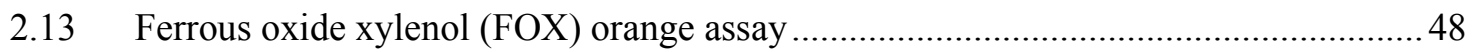

2.14 Determination of superoxide dismutase and catalase activities ................................ 48

2.15 Determination of advanced oxidation protein products (AOPPs) .............................. 49

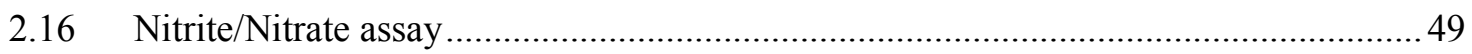

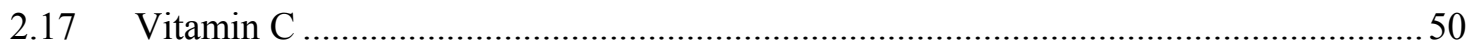

2.18 Determination of vitamin A and $\mathrm{E}$ in liver, lung and brain by HPLC .........................50

Statistical evaluation ............................................................................................................... 51

Chapter 3 ............................................................................................................................ 52

Antioxidant activity of digested oat protein hydrolysates extracted in the presence of

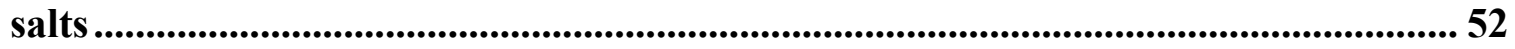

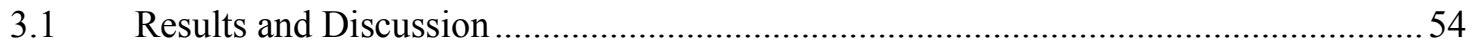

3.2 Scavenging activity of hydrolysates and fractions ...............................................55

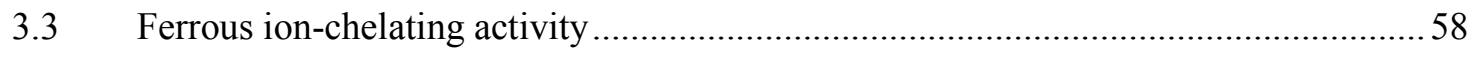

3.4 Linoleic acid autoxidation protection by oat protein hydrolysates.............................59

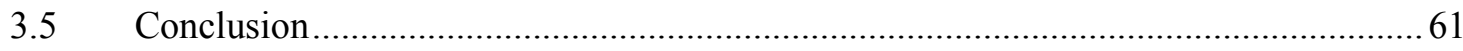

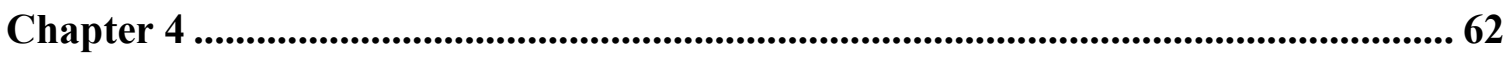

\section{Investigation of the effect of pre-treatment of oat brans with different} carbohydrases on the extraction of protein, and on antioxidant capacity of

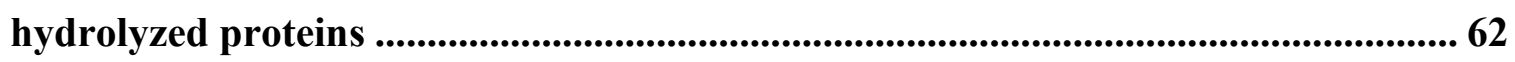

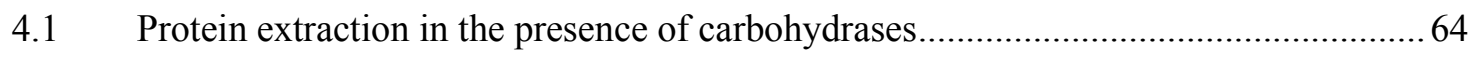

4.2 Antioxidant activities of hydrolysates from bran treated with carbohydrases.............. 66

4.2.1 Oxygen radical absorbance capacity (ORAC) assay .............................................6 66

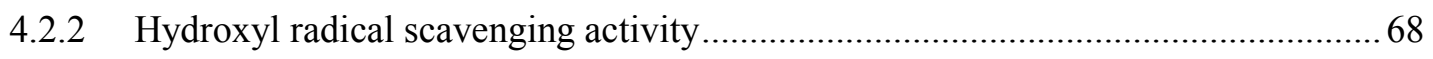

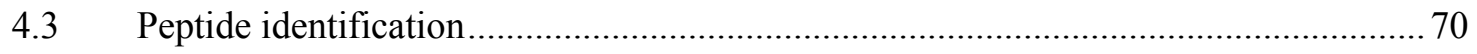

4.4 Possible contribution of identified peptides to antioxidant activities ......................... 73 
Chapter 5

\section{Investigation of the potential of trypsin digested oat bran proteins to reduce} oxidative stress in a mice model receiving high fat diet ........................................ 75

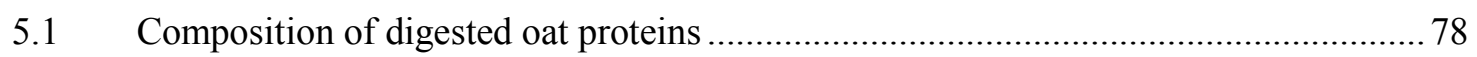

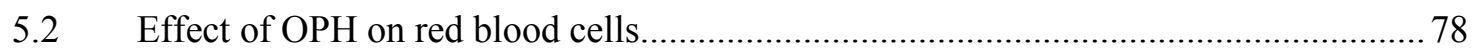

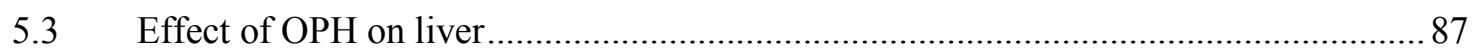

5.4 Measurement of Body Weight, Blood Glucose and Respiratory Exchange Ratio ........91

5.5 Advanced oxidation protein products (AOPPs) level in the brain, plasma, heart, and

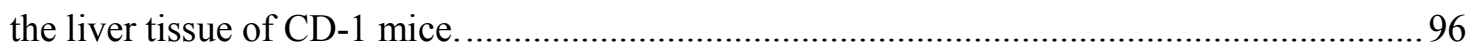

5.6 NO (nitrite + nitrate) level in brain, liver, and the heart tissue ............................... 100

5.7 Effect of $\mathrm{OPH}$ on oxidative stress markers and vitamins A, E, and C levels in the brain tissue 104

5.8 Vitamin A, Vitamin A palmitate, Retinol equivalent level, and vitamins C, E level in the liver tissue of CD-1 mice.

5.9 Vitamin A, vitamin E, retinol equivalents and vitamin C levels in the lung tissue of

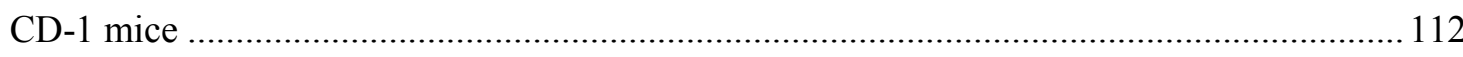

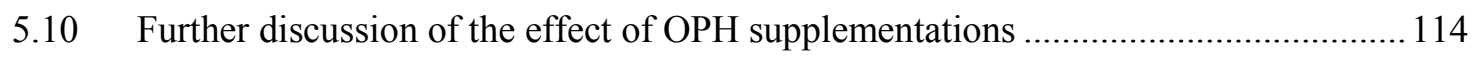

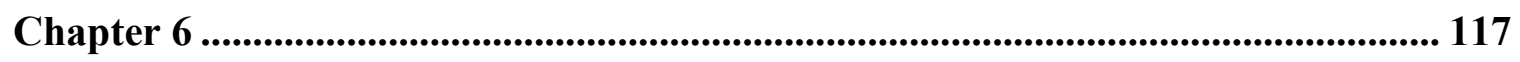

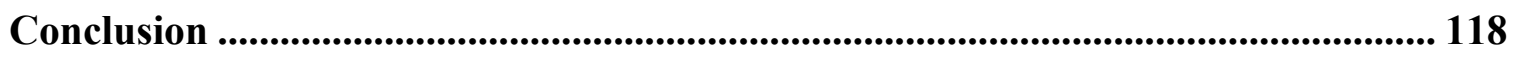

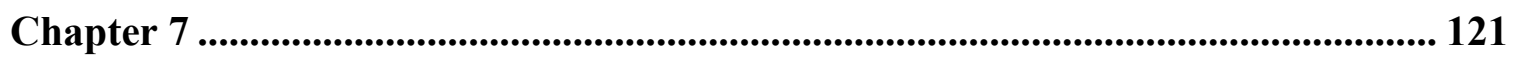

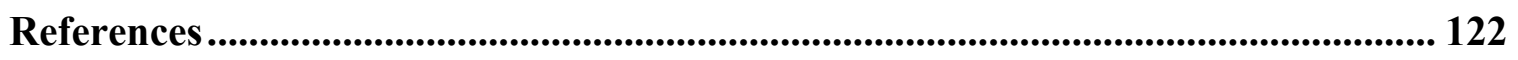




\section{List of Figures}

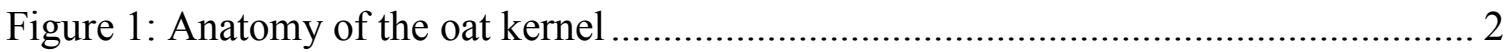

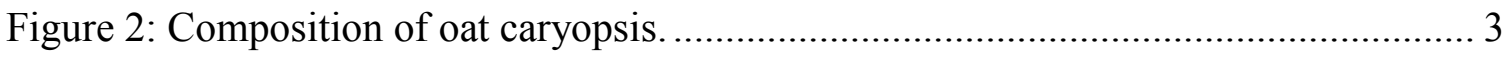

Figure 3: Division of oat carbohydrate composition. .................................................... 4

Figure 4: Primary structure of mixed linkage of $(1 \rightarrow 3,1 \rightarrow 4)-\beta$-D-glucans ..................... 5

Figure 5: Chemical structure of flavonoids identified in oat ......................................... 6

Figure 6: Chemical structures of cinnamic acid derivatives found in the oats .................. 7

Figure 7: Structure of avenanthramides, a unique group of polyphenols found in oat....... 8

Figure 8: Structure of tocols. (a) $\alpha$-tocopherol; (b) and $\alpha$-tocotrienol ................................ 9

Figure 9: Classification of main types of seed proteins based on solubility..................... 11

Figure 10: Resonance structures of a phenol after proton donation to a free radical ....... 15

Figure 11: An illustration of the formation of 8-OHdg, a DNA based oxidation

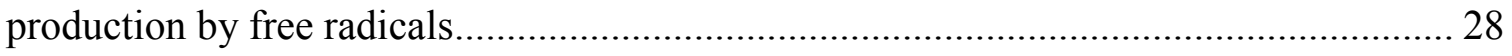

Figure 12: Markers of oxidative damage to proteins, lipids and DNA by ROS ............... 29

Figure 13: Illustration of the role of ROS in metabolic syndrome ................................. 32

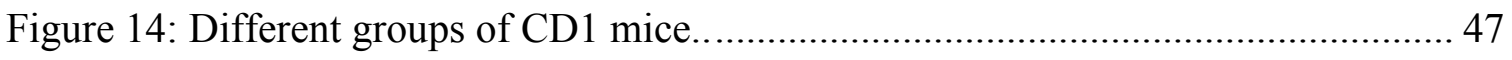

Figure 15: Summary of experiment procedures of work done in chapter 3.................... 54

Figure 16: DPPH radical scavenging of APH, TPH and thier ultra-filtered fractions, $<2$

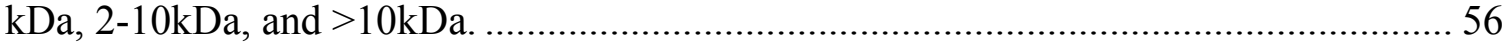

Figure 17: Ferrous ion-chelating activity of the, TPH, APH, and their ultra-filtered fractions. TPH: trypsin digest; TPH 2kDa: trypsin digest $<2 \mathrm{kDa}$; TPH 2-10 kDa: trypsin

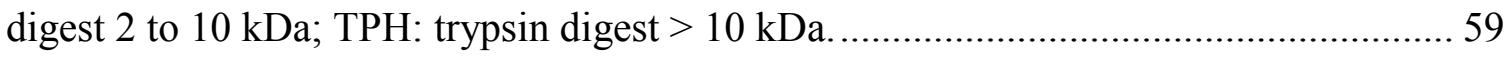


Figure 18: Reduction of lipid peroxides in a linoleic acid emulsion system of APH, TPH,

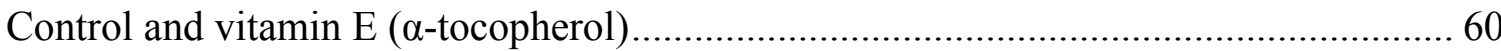

Figure 19: Schematic representation of experimental procedures of work done in chapter

4. 64

Figure 20: ORAC value for protein isolates extracted in brans pretreated with different concentrations of carbohydrases followed by hydrolysis with alcalase. 68 Figure 21: HO• scavenging activity of protein hydrolysates from control bran treated with different concentration of carbohydrases. 69

Figure 22: Ion count chromatogram of oat bran Alcalase hydrolysates. 70

Figure 23: Time of flight MS scan of alcalase digested control oat bran protein at retention time $55.6 \mathrm{~min}$. A: Mass spectrum of peptides eluted between 55.5 and 55.7 min. B: Expansion showing a double charged peak (OAP-1) that automatically submitted for MS/MS analysis. 71

Figure 24: Time of flight (MS/MS) of peptide OAP-1 (m/z 630.34) identified in control, oat bran alcalase protein hydrolysates. 73

Figure 25: Illustration of work done in this chapter. 77

Figure 26: Radical scavenging activity (ORAC) of red blood cells of CD-1 mice. 80

Figure 27: Total sulfhydryl groups in RBC of CD-1 mice. 81

Figure 28: Levels of peroxides determined by FOX assay in the plasma of CD-1 mice.. 82

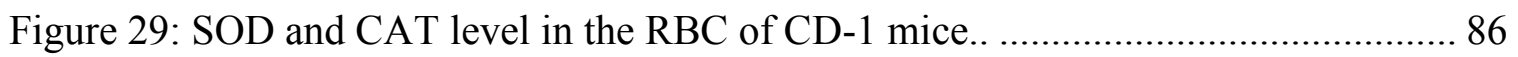
Figure 31: SOD and CAT activity in the liver tissue of CD-1 mice............................ 90 Figure 32: Body weight of the CD-1 mice, during the baseline diet as well as 21 days that animals were on the experimental diet. 91 
Figure 33: Respiratory exchange ratio of the animals.

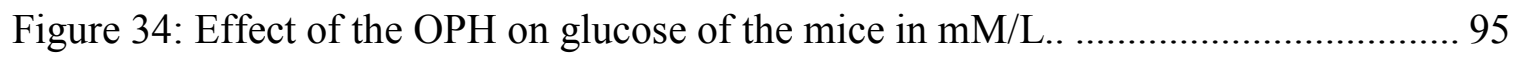

Figure 35: AOPP level in the brain of CD-1 mice in $\mu \mathrm{mol} / \mathrm{mg}$ protein........................ 96

Figure 36: AOPP level in the plasma of CD-1 mice, in $\mu \mathrm{mol} / \mathrm{mg}$ tissue...................... 97

Figure 37: AOPP level in heart of CD-1 mice, in $\mu \mathrm{mol} / \mathrm{mg}$ tissue............................. 100

Figure 38: NO (nitrite + nitrate) level in the brain tissue of CD-1 mice in $\mu \mathrm{mol} / \mathrm{g}$ tissue.

Figure 39: NO (nitrite + nitrate) level in the liver tissue of CD-1 mice in $\mu \mathrm{mol} / \mathrm{g}$ tissue

Figure 40: Vitamin A ( $\mu \mathrm{g} / \mathrm{g}$ of tissue) level in the liver tissue of CD-1 mice............... 107

Figure 41: Vitamin A palmitate level in the mice liver.......................................... 108

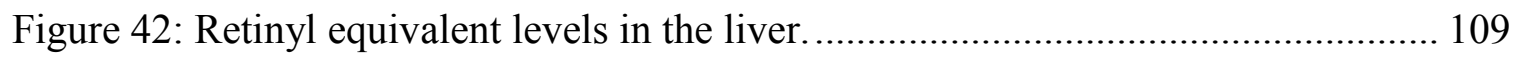

Figure 43: This figure represents the vitamin $\mathrm{C}$ level in the liver tissue of CD-1 mice. 110

Figure 44: Vitamin E level in the liver tissue of CD-1 mice.. ................................. 111

Figure 45: Vitamin A palmitate level in the lung tissue of CD-1 mice....................... 114 


\section{List of Tables}

Table 1: Summary of the composition of normal, high fat (HF) and experimental (HF +

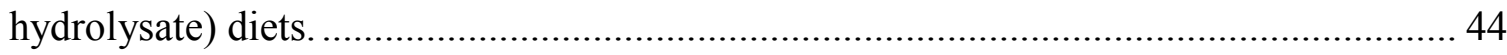

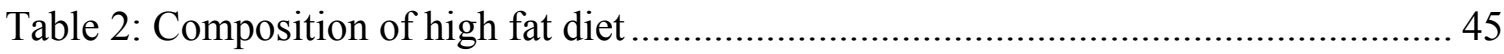

Table 3: Concentration of vitamins in the high fat diet .................................................. 46

Table 4: ORAC values of APH, TPH and their ultra-filtered fractions............................ 57

Table 5: Effect of different concentrations of Amylase, celluclast, viscozyme, and amyloglucosidase on protein content; antioxidant activity (ORAC value $\mu \mathrm{M} \mathrm{TE} / \mathrm{g}$

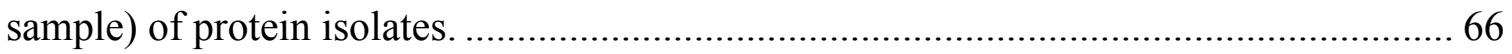

Table 6: Blood glucose, final weight, food intake, locomotor activity and ORAC value in plasma and liver of CD-1 mice in different groups, RBC: red blood cells; ORAC: oxygen radical absorbance capacity assay; TE: Trolox equivalents. ………………………...... 84

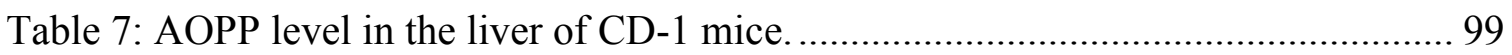

Table 8: Nitrite + nitrate $\mu \mathrm{mol} / \mathrm{g}$ tissue, and Nitrate $\mu \mathrm{mol} / \mathrm{mg}$ tissue in the heart tissue. 104 Table 9: Peroxide level, total GSH and the ORAC value in the brain tissue of CD-1 mic

Table 10: Vitamin A, E, and C $\mu \mathrm{g} / \mathrm{g}$ of tissue, in brain tissue of CD-1 mice................ 106 Table 11: Vitamin A palmitate, Retinol equivalent, vitamins $\mathrm{E}$, and $\mathrm{C} \mu \mathrm{g} / \mathrm{g}$ of tissue, in

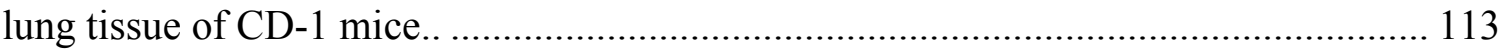




\section{Abbreviations}

AAPH

AOPP

APH

APH 2kDa

$\mathrm{Bc}$

$\mathrm{Bf}$

$\mathrm{Bp}$

CAT

CD

EGU

FOX

$\mathrm{HF}$

HPLC

$\mathrm{HPH}$

MS

NO

ORAC

PH

RNO

ROS

$\mathrm{RBC}$

SOD
2, 2'-azobis (2-amidino-propane) dihydrochloride

Advanced Oxidation Protein Products

Alcalase protein hydrolysate

Alcalase protein hydrolysates $2 \mathrm{kDa}$

N-(3',4'-dihydroxycinnamoyl)-5-hydroxyanthranilic acid

N-(4'-hydroxy-3'-methoxycinnamoyl)-5-hydroxyanthranilic acid

N-(4'-hydroxycinnamoyl)-5-hydroxyanthranilic acid

Catalase

Celiac disease

Endo-glucanase units

Ferrous oxide xylenol

High fat

High-performance liquid chromatography

High-pressure homogenization

Mass spectrometry

Nitrite + nitrate

Oxygen radical absorbance capacity

Protein hydrolysate

Reactive nitrogen species

Reactive oxygen species

Red Blood Cell

Superoxide dismutase 
Trolox Equivalents 


\section{Chapter 1}

\section{Background information}




\subsection{Introduction}

Cereals such as wheat, corn, barley, and oat supply nearly one third of total protein in the human diet in United States and Canada. Proteins from grains have different nutritional properties, and in general, it has been found that those from oat (Avena sativa) have higher amino acid score or good nutritive value compared to the ones from other cereals (Jones et al. 1948; Hartwell 1926). Oats are also a good source of fibers, fat and minerals (Arendt and Zannini 2013b), Oat is a caryopsis, tightly covered by hull. Figure 1 shows the anatomy of the kernel caryopsis (Arendt and Zannini 2013b).

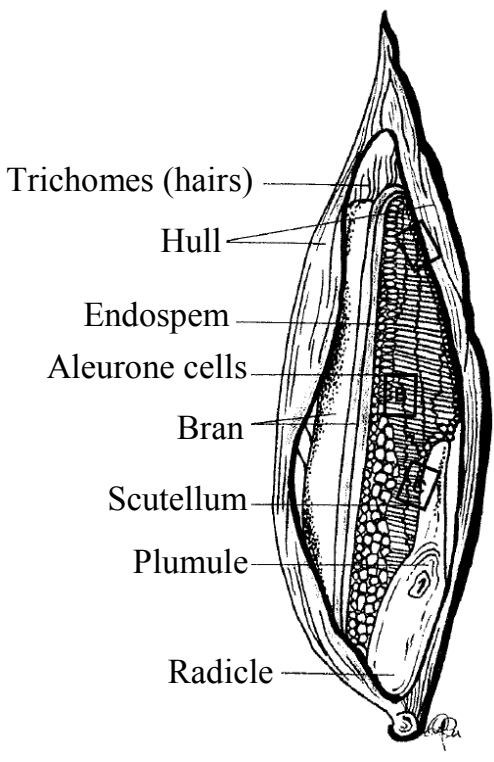

Figure 1: Anatomy of the oat kernel (Arendt and Zannini 2013b) 
The hull constitutes $30-40 \%$ of the total weight, and is mainly composed of cellulose, hemicellulose (Welch 1995), and lesser amount of phenolic compounds and lignin (Arendt and Zannini 2013b). The caryopsis is composed of three main parts, $38-40 \%$ bran, $58-60 \%$ endosperm, and 3\% germ. Bran is rich in vitamins, minerals, phytate, and phytochemicals. The endosperm is the primary storage site for proteins, starches, lipids and $\beta$-glucans. The oat germ, from the chemical point of view, contains high levels of protein, and lipids and little amount of starch. The protein bodies contain phytin globoids, small amounts of calcium magnesium, manganese, and iron (Arendt and Zannini 2013a; Arendt and Zannini 2013b) . Figure 2 summarizes the composition of the oat caryopsis.

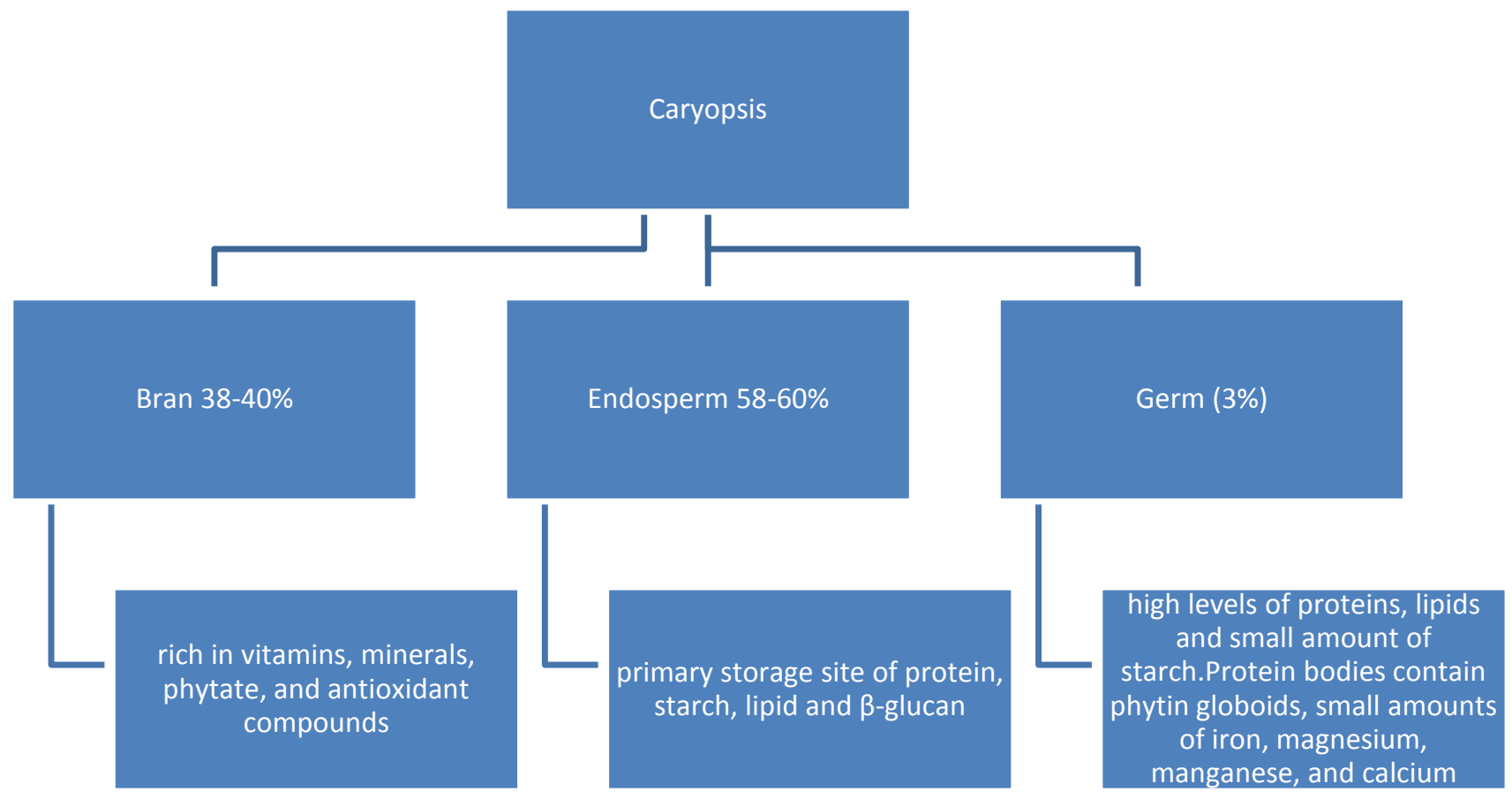

Figure 2: Composition of oat caryopsis 


\subsection{Chemical compounds in oats}

\subsubsection{Polysaccharides or carbohydrates}

The main groups of molecules in oats are carbohydrates. They are composed of $40-50 \%$ starch, dietary fibers, and $\beta$-glucans. Starches are made of amylose and amylopectin while fibers can be divided in two sub-groups based on water solubility. Water-soluble fibers comprise non-starch polysaccharides, gums, pectin, some hemicellulose, arabinoxylan, and $\beta$-glucans. Insoluble fibers contain lignin, and cellulose and hemicellulose. Figure 3 summarizes these various major classes of oat carbohydrates.

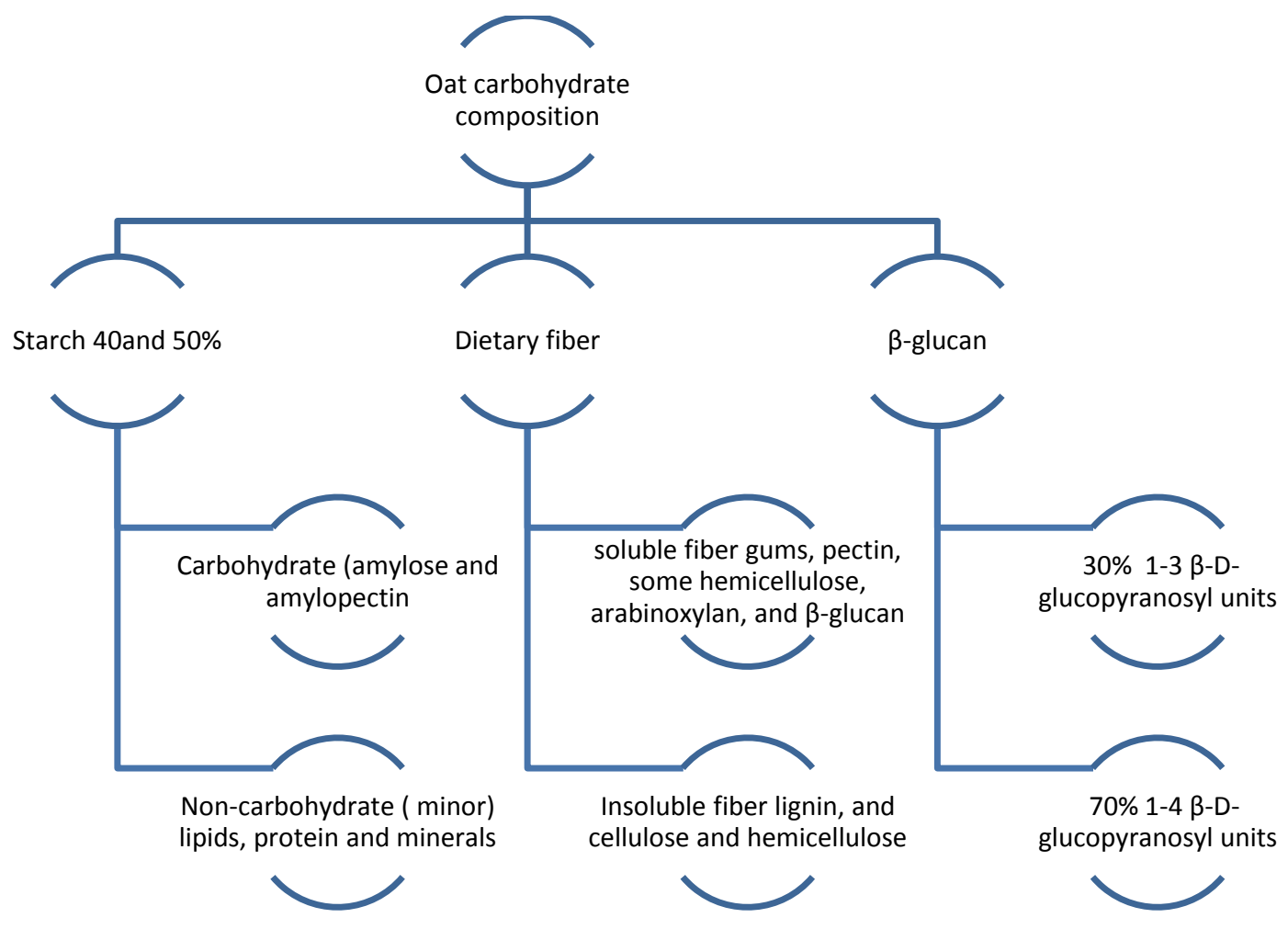

Figure 3: Division of oat carbohydrate composition. 
$\beta$-glucans, major group of soluble fibers in oats and other cereals are composed of $70 \% 1-4$ and 30\% 1-3 $\beta$-D-glucopyranosyl units (Lazaridou and Biliaderis 2007; Arendt and Zannini 2013b)

Figure 4.

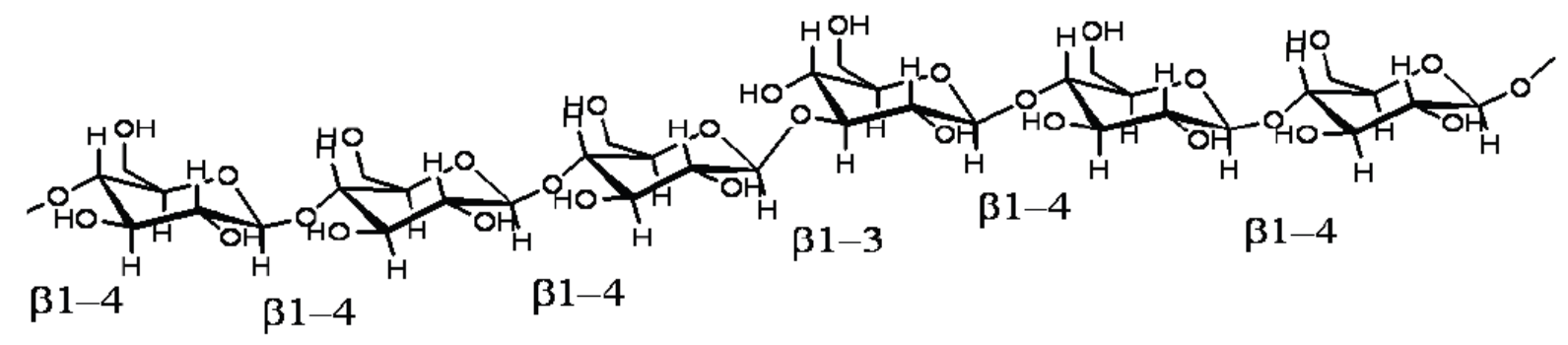

Figure 4: Primary structure of mixed linkage of $(1 \rightarrow 3,1 \rightarrow 4)-\beta$-D-glucans (Nielsen et al. 2008)

\subsubsection{Phenol compounds in oats}

Phenols possess one or more hydroxylated aromatic ring that contribute to their function. They are widely distributed in the plants and are biosynthesized from a precursor called Lphenylalanine. Series of enzymatic reactions lead to generation of phytochemicals with one or more phenolic rings. Based on the structures and number of phenolic rings these phytochemicals can be classified simple such as phenolic acids (contain one phenolic ring), or polyphenols (two phenolic rings) and tannins (complex phenolic derivatives). Many different phenolic derivatives have been found in oats. The vast majority of polyphenols are located in the outer layers of oat kernel. They are present in free (simple), polymeric and conjugated forms. Phenolic acid are divided into four main different classes: phenolic acids, flavonoids, stilbenes and lignans. Flavonoids are the most studied subgroup and are divided into six subclasses: flavonols, flavones, flavanones, flavanols, anthocyanins and isoflavones. Phenolic acids are further divided 
in to subclasses, benzoic acid and cinnamic acid. In oat $60-80 \%$ of phenols are conjugated with polysaccharides, proteins or lipids. Different groups of polyphenols listed below have been identified in oat.

- Flavonoids: Three major flavones identified in oat flour are apigenin, luteolin, and tricin. Glycosidic derivatives such as 6-C and 8-C-glucoside of apigenin, 3-O-rutinosides of quercetin and kaempferol were identified (figure 5) (Peterson 2001).<smiles>[R]c1cc(-c2oc3c([R])c(O)c([R2])c(O)c3c(=O)c2[R])cc([R])c1O</smiles>

$$
\begin{aligned}
& \text { Glu = glucoside } \\
& \text { rut = rutinoside }
\end{aligned}
$$

\begin{tabular}{llllll} 
& R & $\mathbf{R}^{1}$ & $\mathbf{R}^{2}$ & $\mathbf{R}^{3}$ & $\mathbf{R}^{4}$ \\
\hline Apigenin & H & H & H & H & H \\
Apigenin-6-C-Glu & H & H & Glu & H & H \\
Apigenin-8-C-Glu & H & Glu & H & H & H \\
Luteolin & H & H & H & H & OH \\
Tricin & H & H & H & $\mathrm{OCH}_{3}$ & $\mathrm{OCH}_{3}$ \\
Kaempferol & OH & H & H & H & H \\
Kaempferol-3-O-rut & O-rut & H & H & H & H \\
Quercetin & OH & H & H & H & OH \\
Quercetin-3-O-rut & O-rut & H & H & H & OH
\end{tabular}

Figure 5: Chemical structure of flavonoids identified in oat (David M. Peterson 2001). 
- Simple phenolic acids: they are commonly derivative of Cinnamic acids are, Cinnamic acids include $p$-coumaric acid, Caffeic acid, Ferulic acid, Sinapic acid (figure 6) (Bratt et al. 2003).

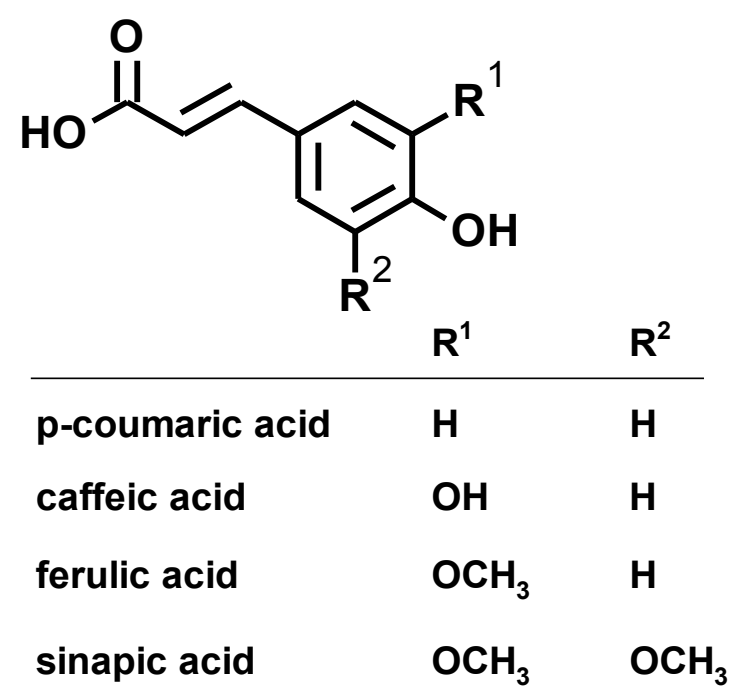

Figure 6: Chemical structures of cinnamic acid derivatives found in the oats (Bratt et al. 2003)

- Avenanthramides: This is unique group of amides or nitrogen containing constituents found in oats, and they contribute to its the antioxidant activity, Figure 7 shows the chemical structure of the avenanthramides found in oats (Bratt et al. 2003). 


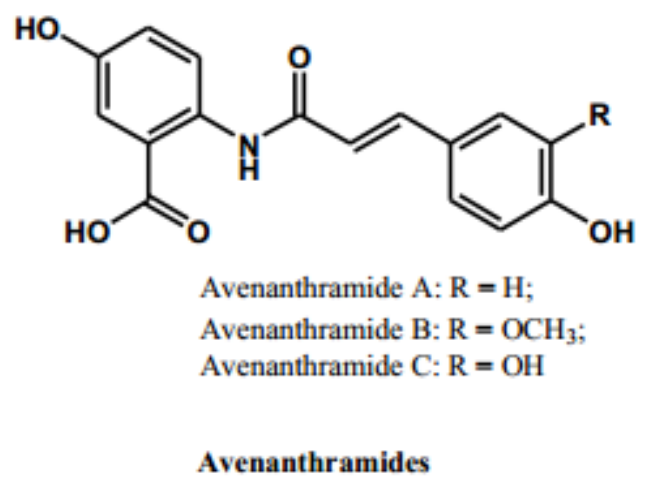

Figure 7: Structure of avenanthramides, a unique group of polyphenols found in oat (Bratt et al. 2003).

Tocopherols are class of organic compounds that have vitamin E activity. The generic name for the eight tocols is vitamin E, E-vitamers is used to describe them collectively. $\alpha$-tocopherol, $\beta$ tocopherol, gamma-tocopherol delta-tocopherol (Figure 8a) and $\alpha$-tocotrienol, $\beta$-tocotrienol, gamma-tocotrienol, delta-tocotrienol (Figure 8b). They have a similar structure, however, they differ in number and location of methyl groups on the ring structure (Indel et al. 2010). The main tocol found in oat is $\alpha$-tocotrienol and smaller amount $\alpha$-tocopherol (Peterson 2001). The germ is source of tocopherols and endosperm is source of tocotrienols. 

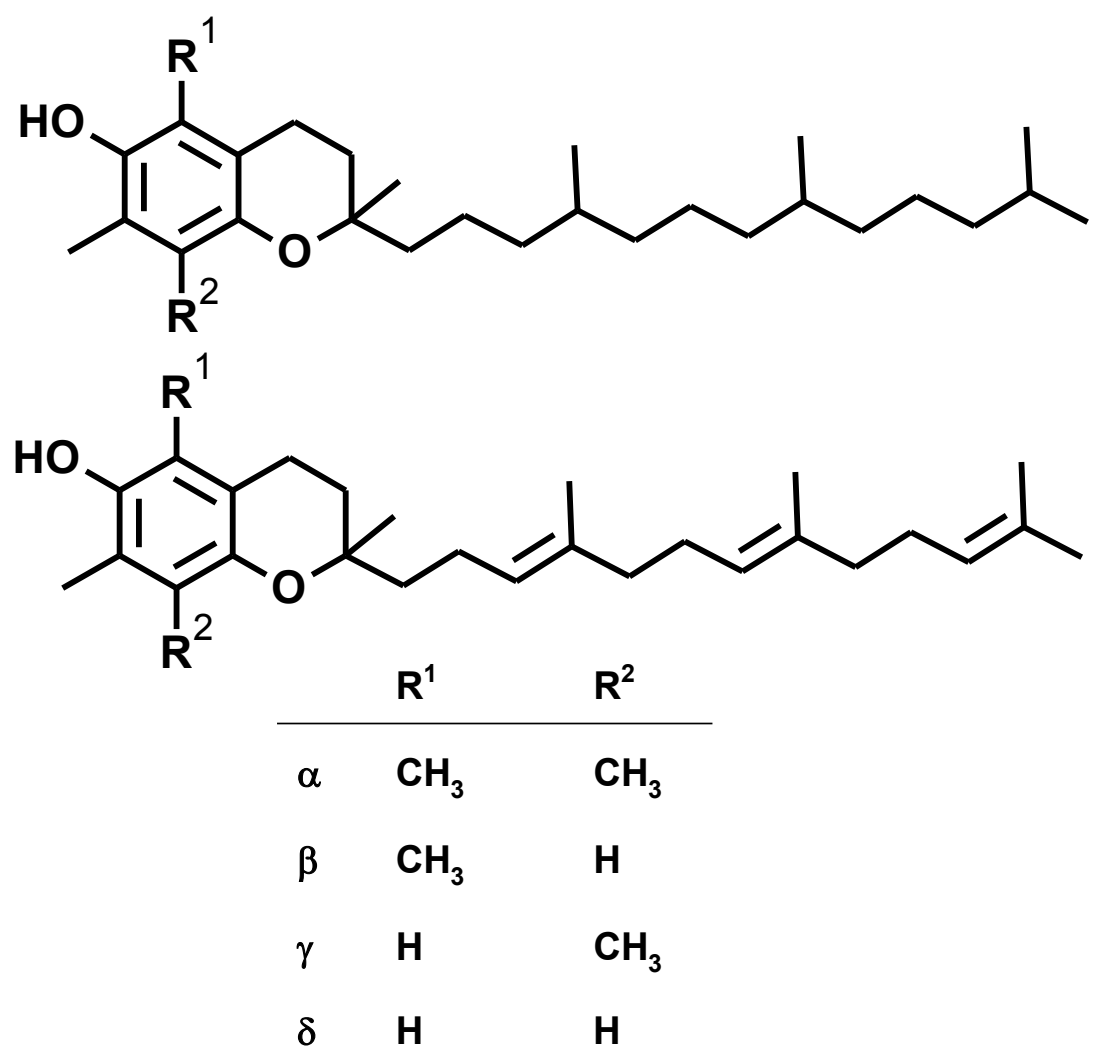

Figure 8: Structure of tocols. (a) $\alpha$-tocopherol; (b) and $\alpha$-tocotrienol (David M et al., 2001).

\subsubsection{Proteins}

Proteins are made of small subunits called amino acids that are linked together by a covalent bond called peptide bonds (Bernhard 1968). Peptides are classified based on the number of amino acid units in the chain, each unit is amino acid residue. For example when two amino acids are linked together they are called dipeptides, if three amino acids are linked together they are called tri-peptide, four amino acids linked together are called tetra-peptides, 12 amino acids, less than 20 linked together are referred as oligopeptides, and when the chain exceeds several dozen amino acids they are called polypeptide. Proteins are composed of one or more polypeptide chains. Proteins with one polypeptide chain are called monomeric proteins, and 
proteins composed of more than one polypeptide is called multimeric proteins. The term homomultimeric is used when the protein is made of one type of polypeptide, and the term heteromultimeric is used when the protein is made of several different polypeptides. Typically, polypeptide chains are made of 100-2000 amino acids.

Oats contain $15-20 \%$ of proteins by weight. The embryo contains the higher amount of proteins (over 30\%) followed by bran (20\%), endosperm (10\%) and the hulls (>2\%) (Youngs 1972). Globulins are the major oat storage proteins, and are linked with higher nutritional value of oat proteins since they are higher in lysine compared to globulins from other cereals. Prolamins are other storage proteins that are present in higher levels in cereals such as rye (40$50 \%$ ) and wheat (30-50\%), however they only accounted for $10-15 \%$ of proteins in oats. Chemical analyses of oat proteins have shown that their amino acid balance is superior to other cereals. Lysine content of oat protein is high (4.2\%) however it is below the recommended level of $4.5 \%$ (FAO/WHO/UNU 2007). In most of the other cereals, increase of proteins content is relative to increase in prolamins (low in lysine) content, therefore the decline in quality of their proteins. However, in oats increase of the protein is relative to increase of globulin fraction, leading to higher quality. Seed proteins are classified into four different types based on their solubility, globulin, prolamins, albumins, and glutelins (figure 9). Oat storage proteins are made of globulins and prolamins. Usually globulins represent $75 \%$ of total seed proteins. Globulins can be identified with three different sedimentation coefficients (3S, 7S, and $12 \mathrm{~S})$. The presence of specific proteins rich in proline and glutamine in other cereal proteins has been described as main triggering in celiac disease $(\mathrm{CD})$, and since oat does not contain them, they are often included in CD diet (Arendt and Zannini 2013a; Arendt and Zannini 2013b). 


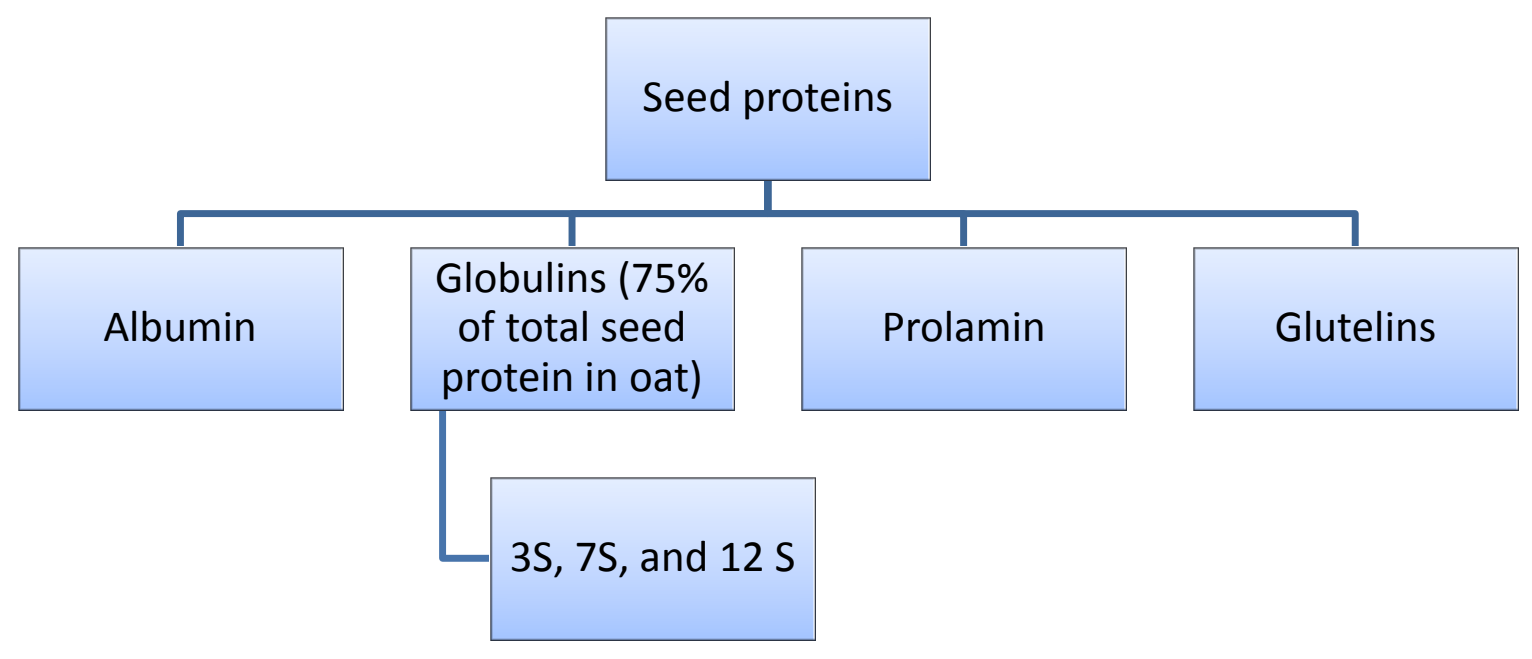

Figure 9: Classification of main types of seed proteins based on solubility

\subsubsection{Other chemicals}

Oats contain lipids, vitamins and minerals. Lipids are an excellent source of energy and some unsaturated fatty acids are essential to human nutrition. Minerals in oats are phosphorous, potassium, calcium, magnesium, iron, copper and manganese. Vitamins such as thiamin and pantothenic acid are present in high amounts. Riboflavin and folic acid are also present (Welch 2005). Oats also contain other components such as sterols, saponins and phytic acids (Ryan et al. 2007; Arendt and Zannini 2013b).

\subsection{Bioactivity of oat compounds}

Consumption of oats and other grains have been associated with reduce risks of chronic diseases like cardiovascular diseases, diabetes, obesity and certain forms of cancer. The observed 
beneficial effect can be attributed to individual compounds as well as to the synergetic effect of several molecules.

\subsubsection{Activity of dietary fibers}

Fibers are non-digestible carbohydrates, meaning resistant to hydrolysis by human digestive enzymes but are fermented by bacteria in the colon. Oat bran is commonly used in breakfast cereals due to its high content of glucans. Consumption of oatmeal and oat bran in glucans have been demonstrated to lower LDL cholesterol. Oat is known to reduce risk of cardiovascular disease and lower cholesterol (Welch 1995). Cholesterol lowering property is due to presence of high amount of soluble fibers ( $\beta$-glucans) which are considered anti-atherogenic but, can also enhance immune system and protect against infection (Qureshi et al. 1986). The hypocholesterolemic mechanism of fibers is linked to cholesterol absorption, influence on bile acid absorption, production of lipoproteins in liver and removal of lipoproteins in peripheral tissues (Anderson and Gustafson N 1988). Dietary fibers increase the viscosity of the contents in the intestine, leading to slower absorption of cholesterol, another hypothesis is that soluble fibers are fermented in the colon, and produce short chain fatty acids, and these acids are absorbed from the colon, one of these acids is propionate, and this acid inhibits cholesterol synthesis. One more hypothesis is that fibers from oat increase short chain fatty acids, inhibiting the cholesterol synthesis in the peripheral tissues, resulting in lower low density lipoprotein (LDL) receptors, which could increases the rate of LDL clearance (Anderson and Gustafson N 1988).

Many studies have investigated the effect of dietary fibers on the body weight of human and animal models. It has been shown that there is an inverse relationship between consumption of dietary fibers and body weight. A study with 89, 432 healthy European participant, free from 
cancer, cardio vascular diseases, diabetes age 20-78 years old, was followed for 6.5 years, showed that there was an inverse relationship between the intake of dietary fibers and the body weight as well as the waist circumference. This study found that higher intake of fibers from cereal and grains was associated with lower body weight and lower waist circumference. However intake of fibers from fruits and vegetable was not associated with body weight change, but the effect on waist circumference was similar to the effect of cereal dietary fibers (Du et al. 2010). In a study where diet of 252 women was measured using 7 day weighted food records, dietary fiber intakes were demonstrated to reduce the body weight and fat independent of physical activity and dietary fat intake (Tucker and Thomas 2009). A study that investigated the body weight and consumption of the whole grain and refined grain of 74, 091 US healthy female nurses free from cancer, cardio vascular disease, age 38-63 year old in years 1984, 1986, 1990, and 1994 through validated food frequency questionnaires concluded that consumption of whole grain dietary fiber is inversely associated with body weight gain (Liu et al. 2003).

Fibers antitumor activity has been attributed in some studies to the presence of phenolic molecules like phytate, and isoflavones present in fiber samples (Cohen 1999). Colorectal cancer is one of the conditions where dietary fibers have been suggested to play a positive role in its prevention. The outer brain layer of these grains contain phenolic polymer such as lignin, which reduces the digestibility of polysaccharides by the digestive enzymes in the colon, making the fecal bulky and making the transit time lower. As well, lignin makes the cell walls hydrophobic; this property increases the cell ability to absorb carcinogens (Harris and Ferguson 2014).

Soluble fibers also slow the increase of blood glucose, which is important in the management of type II diabetes. $\beta$-Glucans are also well known for their positive effects on 
insulin (Wood 2007). The ingestion of oat products decreases the glycemic index, the insulin response in both diabetics and healthy individuals (Jenkins et al. 1981; Heaton et al. 1988). A study conducted using the soluble fiber psyllium on 12 men, mean age 67.5 year and 8 women mean age 66 year who had type 2 diabetes reported a decreased in glucose absorption, as well was decreased levels of LDL cholesterol, and uric acid in the treatment group and had no effect on the absorption of minerals and vitamins A, E (Sierra et al. 2002). Fiber had been demonstrated to improve blood glucose in both overweight and normal weight women (Behall et al. 2006). Fibers enriched biscuits have been shown to reduce blood glucose, increase serum insulin, and increase high-density lipoprotein cholesterol levels in albino rats of Wister strain that were on the fibers enriched biscuits treatment for two weeks (Erukainure et al. 2013)(Erukainure et al. 2013)(Erukainure et al. 2013)(Erukainure et al. 2013)(Erukainure et al. 2013)(Erukainure et al. 2013)(Erukainure et al. 2013)

\subsubsection{Activity of phenolic compounds}

Polyphenols are bioactive molecules and are believed to exert their effect mostly through their antioxidant properties. Antioxidant compounds protect the plants cells against free radicals; this protective effect is transferred to human when it is consumed (Pandey and Rizvi 2009). Their addition of antioxidants to foods is common to increase the shell life through inhibition of polyunsaturated fatty acids oxidation (reduce nutritional value). In vivo antioxidants protect cell membranes from oxidative stress.

Tocopherols, group of lipophilic antioxidant with similar structures but slightly different biological and antioxidant activity (Brindzová et al. 2008). Alpha-tocopherol (Vitamin E) is the most active form. It is fat soluble antioxidant and protects fatty acids in adipose tissue and cell 
membrane from oxidation. It also inhibits oxidation of blood lipid; oxidative stress in lungs, skin, eyes, liver, and other organs (Indel et al. 2010). Ferulic acid is one of the major simple phenol in oats. This acid is has shown to have radical scavenging activity that increases with esterification (Kikuzaki et al. 2002). Phytic acid can reduce cell proliferation by increasing the activity of the natural killer cells (Reddy 1999). An illustration of a free radical reacting with phenolic compound is shown in figure 10. Phenols easily oxidize therefore they prevent oxidation of other compounds. The two hydroxyl radical on phenol has a tendency to react with free radical oxygen, to form a semiquinone, then a quinone, and at the end the free radicals are scavenge.

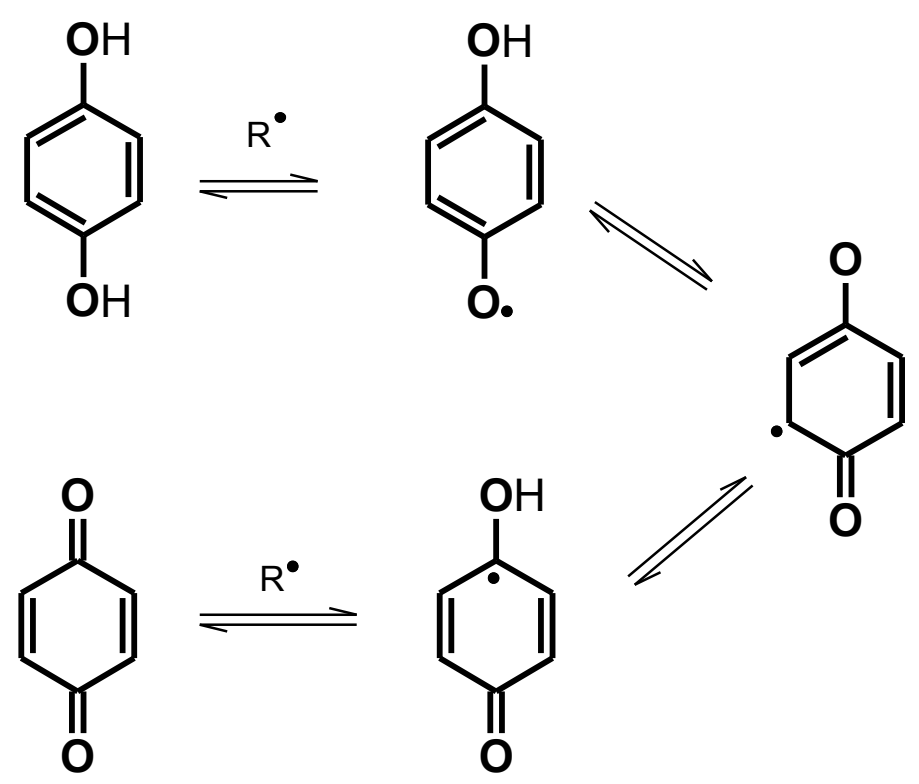

Figure 10: Resonance structures of a phenol after proton donation to a free radical

Avenanthramides are alkaloids that occur only in oats. They are low in molecular weight; phenolic compounds found in the bran at concentrations of about $300 \mathrm{ppm}$. The three most abundant avenanthramides, are $\mathrm{N}$-(4'-hydroxy-3'-methoxycinnamoyl)-5-hydroxyanthranilic acid (Bf), N-(4'-hydroxycinnamoyl)-5-hydroxyanthranilic acid (Bp), and N-(3',4'- 
dihydroxycinnamoyl)-5-hydroxyanthranilic acid (Bc). Their antioxidant capacity has been studied in $\beta$-carotene system as well as DPPH system and all three have potent activities. Bc had the higher antioxidant capacity compared to the other two avenanthramides. In addition, $\mathrm{Bc}$ and Bf were more active than 6-hydroxy-2,5,7,8-tetramethylchromane-2-carboxylic acid (Trolox) (Peterson et al. 2002). A study conducted on human adults who consumed skimmed milk supplemented with avenanthramides $0.5-1 \mathrm{~g}$ showed that avenanthramides were bioavailable and increase plasma antioxidant capacity (Chen et al. 2007). In hamsters, avenanthramides act synergistically with vitamin C to protect against LDL oxidation (Chen et al. 2004a). Other than antioxidant activity, they have shown to have anti-inflammatory activity as well (Liu et al. 2004), and inhibited the secretion of proinflammatory cytokines interleukins IL-6 and IL-8 in endothelial cells (Guo et al. 2008). Anti-atherosclerotic activity of avenanthramides has been also reported (Chen et al. 2007).

Bioavailability of each polyphenol is different. Some are absorbed in the intestine and some are absorbed in gastro-intestinal, or other parts of digestive tracts. For example, Flavonoids are absorbed by the small intestine, anthocyanins are absorbed from the stomach (Passamonti et al. 2005). Studies have shown that polyphenols can penetrate in to tissue. Accumulation of polyphenols in the tissue is important because of the biological activity of polyphenols, health benefits of polyphenols depends on both intake and bioavailability.

\subsubsection{Activity of proteins/peptides}

Protein isolate and protein concentrate has been attracted interest because of their functional properties, such as antioxidant, antihypertensive, and anti-obesity properties. Few studies have investigated the functionality of oat proteins. Only one study investigated the antihypertensive 
properties of hydrolysed oat proteins prior to my study (Cheung et al. 2009). Many studies conducted on hydrolysed proteins from other food have been reported to possess various functions. In vitro, cell culture and animal experiments have demonstrated antioxidative (Cheng et al. 2014), cholesterol lowering (Cai et al. 2014) anti-proliferative (Parrado et al. 2006), and hepatoprotective (Yu et al. 2012) for hydrolyzed proteins from wheat, rice and corn. Proteins extracted from soybean, and treated with proteinase, Alcalase, trypsin, or chymotrypsin resulted in low molecular weight peptides such as Leucine-Leucine-Proline-Histidine-Histidine or LeuLeu-Pro-His-His, which possessed both antioxidant and antihypertensive effect (Chen et al. 1996; Wu and Ding 2002). Antioxidant peptides have also been obtained from chickpea, white beans, and milk proteins.

The antioxidant activity of proteins depends on the amino acid constitute, for example amino acids that are aromatic donate protons to free radicals, few examples of such amino acids are tyrosine, phenylalanine, and tryptophan as well as sulfur containing amino acids like cysteine. Glutamate, and aspartate are acidic amino acids, and lysine, arginine are basic amino acids. These amino acids scavenge free radicals by metal chelating ions. Histidine amino acid has imidazole ring, and because of this ring, histidine amino acid has metal chelating and free radical scavenging activity. The positioning of amino acids in the protein has an important role in the protein antioxidant activity. Each peptide has different antioxidant activity depending on the proline at the $\mathrm{N}$-terminus as well as $\mathrm{C}$ - terminus. Proline at the $\mathrm{N}$-terminus is better in preventing oxidation of linoleic acid compared to the proline at the C-terminus. Peptides that have histidine at the N-terminus are better metal chelating compared to peptides having histidine at the Cterminus. Hydrophobicity has been reported to have a close relationship with antioxidant 
activity of peptides as well as proteins, this has been related to the ability to bind and hide unsaturated lipids. Cationic properties of proteins also is related to its antioxidant activity, since lipid oxidation is inhibited by electrostatic repulsion of transition metals away from lipid droplets by the positively charged groups. Other than antioxidant activity, proteins have other functions such as emulsifying activity, for example protein isolate and whey protein are known to have emulsifying activity. Lactoferrin and phosvitin are examples of protein that possess both antioxidant activity as well as anti-microbial activity. Gel formation, flavour binding as well as increase of viscosity are additional functions of proteins. It has been shown that functional and nutritional properties of proteins isolate as well as protein concentrate has been improved by enzymatic hydrolysis.

\subsection{Methods for extraction of proteins}

Different methods of protein and peptide extractions exist based on the solubility, hydrophobicity, molecular weight, and isoelectric point (IP). They are used to remove interfering compounds such as lipids, nucleic acids, carbohydrates, and pigments. Since proteins are inside the proteins bodies in the cell wall, the first step is to break or disrupt cell walls before extraction and solubilisation.

\subsubsection{Cell wall disruption}

Mechanical techniques or blenders are commonly used to break the cell wall without denaturing the proteins. Mechanical homogenization and ultra-sonication have been used for grains (rice), dry legumes (lentils, chickpeas)(Boye et al. 2010). High-pressure homogenization (HPH) also has been shown to produce double the amount of proteins compared to atmospheric pressure. HPH can also increase the susceptibility of proteins to enzymes such as alcalase (Barbin et al. 
2011). Temperature treatment also in another method used for disruption of cell wall plant, using liquid nitrogen to flash freeze the sample and then homogenizing with a pestle, this method is usually used for tomato and olive but it is not suitable for cereals.

\subsubsection{Solubilisation of proteins}

The first step is generally to remove fat. Hexane the solvent most commonly used to achieve this (Tzeng et al. 1990; Wu and Muir 2008), however diethyl ether, acetone, 2-propanol, ethanol and 2-methyl pentane have been used (Bader et al. 2011). Defatted samples are then dried at room temperature or under vacuum in an oven prior to solubilisation of proteins. Organic solvents, aqueous solutions, aqueous enzymatic extraction, or subcritical water are used for solubilisation to extract proteins from different food sources. Aqueous alcohols such as ethanol, butanol, or isopropyl alcohol have been used to remove phenolic and oligosaccharides. However, when the functionality of proteins is important, the use of organic solvents should be avoided as they will denature proteins, resulting in loss/reduced functionality. Aqueous solutions are preferred due to their nontoxicity, non-flammability, and non-denaturing properties.

\subsubsection{Use of salts}

The $\mathrm{pH}$ and ionic strength (i.e. salt concentration) provide electrostatic repulsion factors that can increase protein extractions (Siong et al. 2011). The use of sodium and calcium salts to extract proteins from cereals and other foods is documented in the literature (Ghaly and Alkoaik 2010; Lestari et al. 2010; Karaca et al. 2011; Nadal et al. 2011). These salts are easily available but the yield of the extracted proteins is generally low due to racemization of amino acids and formation of toxic compounds like lysinoalanine (Sereewatthanawut et al. 2008). The consequence is loss of essential amino acids and decrease of nutritive value. Salt solutions containing the proteins 
are often ultra-filtered to purify and concentrate the protein. Then the retentate is diluted with water followed by precipitation of proteins through centrifugation. Compared to alkaline extraction there are less literature for salting method, this could be due to lower protein yield.

\subsubsection{Alkaline treatment}

One of the common ways to extract proteins isolates is alkaline extraction with sodium hydroxide $(\mathrm{NaOH})$ solution, and precipitating it with dilute acid (Aluko and McIntosh 2001; Klockeman et al. 1997). Generally, the defatted sample is stirred or shaken in sodium hydroxide to solubilize the protein, then the sample is centrifuged and the supernatant is adjusted to a specific $\mathrm{pH}$ to precipitate the proteins, and again the sample is centrifuged and protein is separated and freeze-dried. Concentrations of the sodium hydroxide, and the $\mathrm{pH}$, that the sample is being adjusted to precipitate the protein varies. It has been found that $\mathrm{pH}$ range, $4.5-5.5$ is ideal

for protein precipitation (Ghodsvali et al. 2005). For different concentrations of $\mathrm{NaOH}$, different $\mathrm{pH}$ is needed to precipitate the protein, for example, using $0.1 \mathrm{M} \mathrm{NaOH}$, the $\mathrm{pH}$ of the supernatant should be adjusted to 4.0 by $0.1 \mathrm{M} \mathrm{HCl}$ (Aluko and McIntosh 2001; Aluko et al. 2005), or if using $0.4 \% \mathrm{NaOH}$, the $\mathrm{pH}$ is adjusted to 3.5 by acetic acid (Klockeman et al. 1997).

\subsubsection{Pre-treatment with carbohydrases}

There are more than 1500 known enzymes and only few are important to food industry and in human nutrition (Bernhard 1968). Cereals are rich source of starch, dietary fibers and other complex polysaccharides. Some of these are linked to proteins making their extraction difficult. 
Using enzyme that can break cell wall polysaccharides can enhance proteins extraction in cereals. Carbohydrases such as viscozyme L was used increase protein extraction yield in oat bran from $14.8 \%$ to $56.2 \%$ (Guan et al. 2007). In another study, treatment of rice brans with viscozyme L, and celluclase also significantly increased protein contents (Ansharullah et al. 1997). Therefore the use of other cell wall degrading polysaccharides will increase protein extraction from oat brans and their bioactivities.

\subsection{Protein hydrolysates}

Proteases are used to break down proteins into specific peptides and can be evaluated for biological activities in various assays. There are few classes of proteases such as trypsin, chymotrypsin, plasmin, elastase, thrombin, subtilisin, tissue plasminogen activator. It has been demonstrated that in vitro digestion can increase the antioxidant capacity of cereal products. This is because the process can release different molecules than the human gastro-intestinal tract or make increases the solubility of proteins and other complex molecules (Liyana-Pathirana and Shahidi 2006). Gastro-intestinal enzymes such as pepsin, pancreatin, and trypsin are often used. There is a large literature data on the use of alcalase, papain, ficin, proteinase $\mathrm{K}$, or protamex (Ansharullah et al. 1997; Grossman et al. 1980). In certain cases, in vitro digestion under simulated gastrointestinal tract conditions have been used to obtain new bioactive peptides (Pérez-Jiménez and Saura-Calixto 2005). The increase in antioxidant activity of whole cereal grains under in vitro gastrointestinal conditions was explained by higher levels of both hydrolysable phenolic and proteins (Fardet et al. 2008). Antioxidant activity, functional and nutritional properties of hydrolyzed proteins from beans and chickpeas (Arcan and Yemenicioğlu 2007), soy (Chen et al. 1998), and milk (Satué-Gracia et al. 2000) were greatly increased 
compared to intact proteins. Protein hydrolysates may have applications in pharmaceuticals, human and animal nutrition (Bueno-Solano et al. 2009).

\subsection{Antioxidant peptides, structure and function}

The average molecular weights of peptides are generally less than $10 \mathrm{kDa}$ while those of proteins are higher. Peptides shorter than 20 amino acids are the ones that often possess physiological benefits. The bioactive peptides are encrypted in protein polypeptide chains and can be released by fermentation with micro-organisms, chemical or enzymatic hydrolyses as described in section 1.5. Upon released, peptides can now exert their physiological function like reduction of blood pressure(Li et al. 2011), neutralization or scavenging of reactive oxygen or nitrogen species, lowering of blood lipids (Jung et al. 2010) or cholesterol (Marques et al. 2015). Peptides can also increase absorption of calcium and other minerals, inhibit the growth of bacteria. Some peptides contain more than one of these activities and are then designated as multifunctional. Mechanistic studies have demonstrated that peptides with antioxidant activities should have one of these three basic structural features (Aluko 2012); 1) the presence of electron donor groups or aromatic ring that can possess several equilibrium forms after donating a proton. The excess electrons on amino acid side chains can stabilize free radicals and the aromatic ring equilibrium formed prevent the oxidised peptide to become a reactive species; 2) the possession of hydrophobic property, which enhances the translocation of active molecules through the lipid cell membrane into the cytoplasm and mitochondria where free radicals are generated; 3) the ability to chelate transition metals or reduce ferric ions (Aluko 2012).

Protein hydrolysates and peptides with some of these features have been produced from foods such as soy, pea, fish, milk casein, whey, and egg. A number of them possess antioxidant 
properties (Irshad et al. 2015; Chen et al. 1996; Sakanaka et al. 2004; Davalos et al. 2004; Xu et al. 2007; Aoyama et al. 2000). They have been demonstrated, to scavenge or quench free radicals; inhibit oxidization of macromolecules such as lipids, DNA, and proteins and therefore, have application in the reduction of many chronic diseases associated with oxidative stress (Aluko 2012).

In addition to features mentioned above, the amino acid (AA) composition or the position of AA on the sequence has an influence on the antioxidant activity of peptides (Udenigwe and Aluko 2011). Some of the important AAs are histidine, cysteine, proline, methionine, tyrosine, tryptophan and phenylalanine. The presence of imidazole group in histidine and indole in tryptophan can increase their metal chelating activities, and quenching of superoxide anion and hydroxyl radicals (Grune et al. 2013). This is because both residues can participate in hydrogen atom transfer and single electron reactions resulting in neutralizing the free radicals. The addition of hydrophobic amino acids such as proline, and leucine to the N-terminus of the dipeptide HisHis resulted in increased antioxidant activity (Aluko 2012). Electron dense aromatic rings in phenylalanine and tyrosine contribute to their metal chelating property; they can also scavenge hydroxyl radicals thereby forming stable hydroxylated derivatives (Remko et al. 2011). Sulfhydryl (-SH) group present in cysteine has proton donating ability while sulfur in methionine can be oxidised (instead of biological molecules) to form stable sulfoxides (Cheng et al. 2011). Acidic amino acids such as glutamic acid and aspartic acid have electron donating ability that contribute to the DPPH scavenging activity, $\mathrm{H}_{2} \mathrm{O}_{2}$ scavenging and ferric reducing of some food protein hydrolysates (Ajibola et al. 2011). Some peptides containing AA like lysine and leucine have poor hydroxyl radical scavenging or metal chelating properties but good superoxide and 
$\mathrm{H}_{2} \mathrm{O}_{2}$ scavenging effect while proline, phenylalanine and tyrosine have lower superoxide radical scavenging properties (Aluko 2012). Ferric reducing activity of the protein hydrolysates has been shown to be enhanced by the presence of cysteine, methionine, and glutamic acid (Ajibola et al. 2011) while the presence of lysine lowered the activity. DPPH radical scavenging effect of protein hydrolysates may depend on aspartic acid, threonine, valine, and isoleucine but presence of histidine, lysine and arginine have the opposite effect (Aluko 2012). Peptides that can donate cysteine to synthesis of glutathione (GSH) are important for antioxidative activities (Aluko 2012).

\subsection{Oxidative stress}

Oxidative stress is a term that describes the oxidative damage in a cell, organ, or tissue caused by excess reactive oxygen species (ROS) and nitrogen species (RNS) species. ROS are by product of essential and normal metabolic reactions derived from oxygen species in all aerobic organisms. Excess ROS can damage normal body function or lead to abnormal cell death (Pierce et al. 1991). Many health benefits of oats or its constituents as discussed in section 1.3 are associated with their effects on oxidative stress.

\subsubsection{Reactive oxygen species and reactive nitrogen species}

Reactive Oxygen species (ROS) and reactive nitrogen species (RNS) are highly reactive and are naturally present in the human body. ROS/RNS react with other molecules such as lipids, proteins, nucleic acids, fats, DNA and carbohydrates by either donating an electron or accepting an electron from another molecule (Davis et al. 2010). 
Few examples of ROS/RNS are $\mathrm{O}_{2}{ }^{\circ}, \mathrm{HO} \bullet, \mathrm{NO}^{\bullet}, \mathrm{ONOO}^{-}, \mathrm{HOCl}, \mathrm{RO}(\mathrm{O}) \bullet, \mathrm{LO}(\mathrm{O}) \bullet$, (Prior et al. 2005) and they fall in to two categories, one category is molecules that contain unpaired electrons such as superoxide anion $\mathrm{O}_{2} \bullet-$, hydroxyl ion $\mathrm{OH}^{-}$, and hydroxyl radical $\bullet \mathrm{OH}$ and react directly with biological molecules. The other category is molecules that have the ability to pull electrons from other molecules $\left(\mathrm{H}_{2} \mathrm{O}_{2}\right.$ or $\left.\mathrm{HOCl}\right)$ and can damage bimolecular through direct interaction or starting a chain reaction where ROS/RNS are transferred from molecule to molecule (Zulueta et al. 2009a).

Superoxide anion $\left(\mathrm{O}_{2}^{-{ }^{-}}\right)$is produced from $\mathrm{O}_{2}$ molecule that acquired an electron (Equation 1).
Equation 1
$\mathrm{O}_{2}+\mathrm{e}^{-} \rightarrow \mathrm{O}_{2}^{-\cdot}$

Hydrogen peroxide is produced via superoxide anion $\left(\mathrm{O}_{2}^{-{ }^{-}}\right)$in the presence of antioxidative enzyme Superoxide dismutase (SOD) (Equation 2).
Equation 2
$2 \mathrm{O}_{2}^{-\cdot}+2 \mathrm{H}^{+} \stackrel{S O D}{\longrightarrow} \mathrm{H}_{2} \mathrm{O}_{2}+\mathrm{O}_{2}$

In the presence of high iron concentration hydrogen peroxide $\left(\mathrm{H}_{2} \mathrm{O}_{2}\right)$ can be converted to hydroxyl radical (HO•) (Equation 3).
Equation 3
$\mathrm{H}_{2} \mathrm{O}_{2} \stackrel{F e 2+}{\longrightarrow} \mathrm{HO} \bullet$

Highly reactive peroxynitrite $\left(\mathrm{ONOO}^{-}\right)$is also formed via reaction of superoxide anion with nitric oxide (Hazel 2006)(Equation 4).
Equation 4
$\mathrm{O}^{-\bullet}+\mathrm{NO} \bullet \rightarrow \mathrm{ONOO}^{-}$ 


\subsubsection{Reaction of ROS/RNS with biomolecules}

Antioxidants inhibit or reduces generation of free radicals, eventually leading to delay or even prevent oxidation reactions, such as lipid oxidation. Lipids are components of cell membrane that are vulnerable to oxidation upon introduction of free radicals, high temperatures, lights, oxygen, and pro-oxidants. In food this oxidation can cause food rancidity, undesirable taste, odors and decrease nutritional value of food. Lipid oxidation products are harmful to mammalian cells, they can effect cell division as well as cell proliferation, and it can result in inflammation. The steps of lipid auto-oxidation are shown below.

Radical initiation

$$
\mathrm{RH}+\mathrm{O}_{2} \rightarrow \mathrm{R} \cdot+\cdot \cdot \mathrm{OH}
$$

Radical propagation:

$$
\begin{gathered}
\mathrm{R} \cdot+\mathrm{O}_{2} \rightarrow \mathrm{ROO} \bullet \\
\mathrm{ROO} \cdot+\mathrm{RH} \rightarrow \mathrm{R} \bullet+\mathrm{ROOH} \\
\mathrm{ROOH} \rightarrow \mathrm{RO} \bullet+\mathrm{HO} \bullet \\
\mathrm{RO} \bullet+\mathrm{RH} \rightarrow \mathrm{R} \bullet+\mathrm{ROH} \rightarrow \text { oxidation products }
\end{gathered}
$$

Radical termination:

$$
\begin{gathered}
\mathrm{R} \cdot+\mathrm{R} \cdot \rightarrow \mathrm{RR} \\
\mathrm{R} \cdot+\mathrm{ROO} \cdot \rightarrow \mathrm{ROOR} \\
\mathrm{ROO} \bullet+\mathrm{ROO} \rightarrow \mathrm{ROOR}+\mathrm{O}_{2}
\end{gathered}
$$


ROS and lipid peroxides can oxidize proteins thereby altering their function. The protein oxidation is defined as the covalent modification of a protein induced either directly by ROS or by-products of oxidative stress (Andersson and Hellstrand 2012; Berlett and Stadtman 1997). There are different types of proteins oxidation modifications. Protein oxidation can result in oxidation of amino acid residues. $\cdot \mathrm{OH}$ for example can oxidized tyrosine, phenylalanine, tryptophan, histidine, methionine and cysteine (Berlett and Stadtman 1997). As a consequence of oxidation, hydroperoxides, alcohols and carbonyl compounds are formed (Byrne 2002). Breakage of peptide bond in proteins or protein-protein cross links occurs as a results of oxidation, leading to a secondary effects such as protein folding, protein fragmentation and protein aggregation, causing loss of activity and function in proteins. The steps in protein oxidation are shown below.

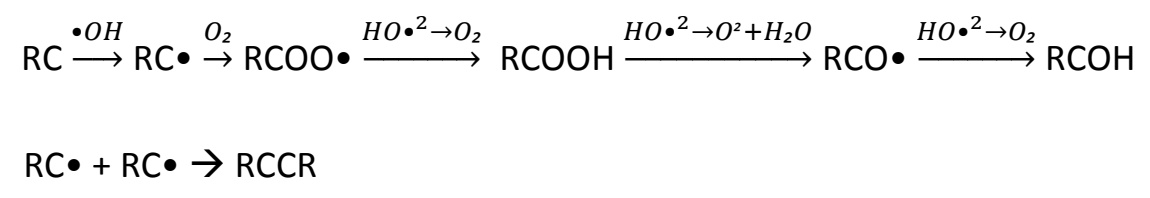

As shown in reaction 1, protein oxidation is initiated by $\mathrm{OH} \bullet$, removing $\mathrm{H}$ atom from aliphatic amino acid resulting in formation of $\mathrm{RCOO} \cdot$ (alkyl peroxide) in presence of $\mathrm{O}_{2}$, and after formation of alkoxyl radical (RCO•), which is then converted to hydroxyl protein derivatives (RCOH). Reaction 2 shows that in absence of $\mathrm{O}_{2}$, the protein-protein cross-linked derivative occurs and then the carbon-centered radical can react with another carbon-centered radical (Berlett and Stadtman 1997). Protein carbonyl is used as marker of the protein oxidation (Berlett and Stadtman 1997). Increased levels have been seen in Alzheimer's diseases, diabetes, and renal failure. In addition, amino acids that contains sulfur such as cysteine and methionine are more sensitive to react with free radicals (Silva,P,F,N. et al. 2006). 
Nucleic acids are sensitive to oxidative damage as well, ROS directly effects DNA, signal transduction, cell proliferation, cell death and intracellular communication. ROS damages DNA by attacking purine and pyrimidine bases and deoxyribose sugars and also by indirect mechanisms. $\mathrm{OH} \bullet$ can cause chemical modification in DNA, through breakage of one and two strands and cross linking with other molecules. Superoxide (O2•-), nitric oxide (NO) or hydrogen peroxide $\left(\mathrm{H}_{2} \mathrm{O}_{2}\right)$ do not react with any of DNA or RNA bases. $\mathrm{OH} \bullet$ reacts with nitrogen bases of nucleic acids or aromatic rings. The main products for the oxidative damage of DNA are 8hydroxyguanosine (8-OHdG), 8-hydroxyadenine (8-OH-Ade), cytocine glycol, and thymine glycol (oxidative damage to DNA). 8-hydroxyeoxyguanosine (8-OHdG) is one of the wellstudied marker of DNA oxidation. Studies have revealed that there is a connection between the oxidation of DNA bases and cancer or inflammatory diseases such as hepatitis (Berlett and Stadtman 1997). Figure 11 shows formation of 8-OHdg by reaction of ROS with DNA.

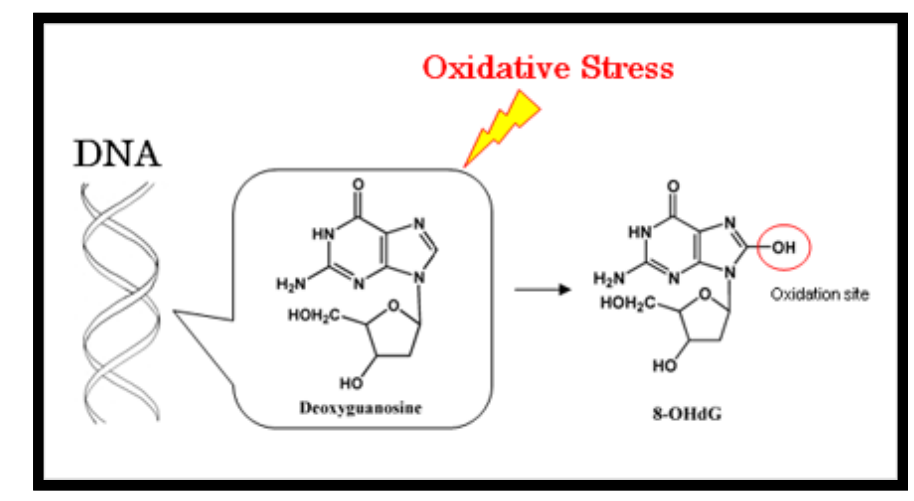

Figure 11: An illustration of the formation of 8-OHdg, a DNA based oxidation production by free radicals 
Oxidative damage by ROS can be measured by its markers, for example protein oxidation can be measured by measurement of thiol groups, ratio of glutathione and oxidized glutathione, or carbonylated proteins. Lipid oxidation can be measured by measurements of malondialdehydes, conjugated dienes, and DNA oxidation can be measured by measurements of (8-OHdG), or 8OH-Ade. Figure 12 summarized the markers of oxidative stress to proteins, lipids and well as DNA.

\section{Proteins

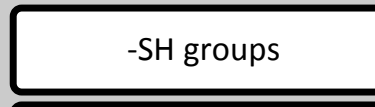 \\ GSH/GSSG \\ 3-nitrotyrosine \\ 3-Chlorotyrosine \\ dityrosine \\ Carbonylated proteins}

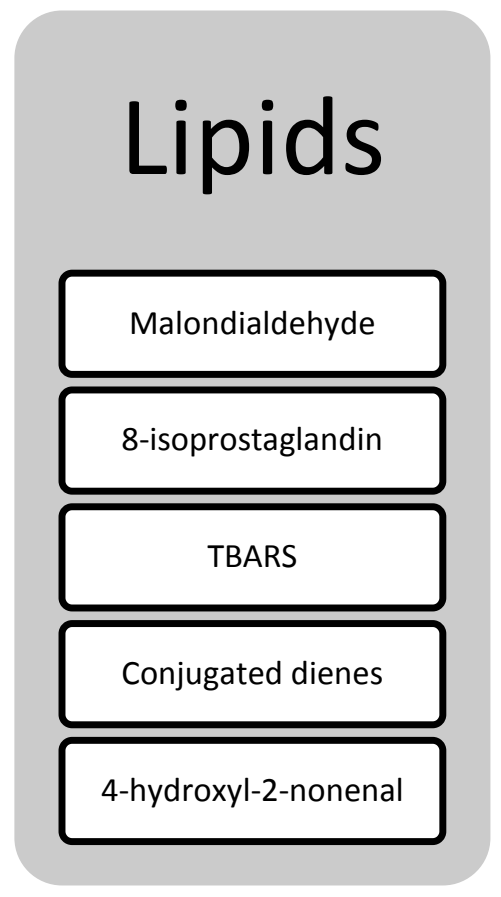

\section{DNA}

2,6-diamino-4-hydroxyformamidopyrimidine

4,6-diamino-5-

formamidopyrimidine

8-hydroxyadenine

8-hydroxyguanosine

5-hydroxycytosine

Figure 12: Markers of oxidative damage to proteins, lipids and DNA by ROS (Babusikova et al. 2013) 


\subsection{Human antioxidant defense system}

In response to free radicals and oxidative damages body produces natural antioxidant to fight against the pro-oxidants. Human's antioxidant defense system plays a significant role in shielding human's body from oxidative damage. Within human biological system there are general sources of antioxidants: (1) enzymes, such as Superoxide dismutase (SOD, EC 1.15.1.1), glutathione peroxidase (GPx), and catalase (CAT); and (2) non-enzymatic antioxidant such as vitamin $\mathrm{C}$, some vitamin B, Vitamin $\mathrm{E}$ and $\beta$-carotene (Cheng et al. 2001). SOD converts superoxide anion to hydrogen peroxide then to oxygen. There are three forms of SOD enzymes. $\mathrm{Cu} / \mathrm{Zn} \mathrm{SOD}$, binds to both copper and zinc, present in cytoplasm. Fe and Mn SOD enzyme that either binds to iron or manganese. Ni SOD binds to nickel. Mn SOD enzyme is present in mitochondria. After SOD enzyme converts superoxide to hydrogen peroxide and oxygen, the hydrogen peroxide is then converted to water by an enzyme name Catalase (CAT, EC 1.11.1.6) to, two $\mathrm{H}_{2} \mathrm{O}$ (water) and one oxygen molecule. This enzyme controls the $\mathrm{H}_{2} \mathrm{O}_{2}$ level in the cells. Glutathione peroxidases (GPXs, EC 1.11.1.9), has peroxidase activity and it protects the organism against oxidative damage. GPx converts $\mathrm{H}_{2} \mathrm{O}_{2}$ in to water and oxygen. Glutathione transferases (GSTs, EC 2.5.1.18) are involved in the cellular detoxification, also they may reduce ROS to less reactive form.

Vitamins acts as free radical scavengers, by donating an electron to the free radical and they become saturated quickly after donating an electron. Vitamin E are fat soluble antioxidants, and their major function is to protect organism against lipid peroxidation, by donating a hydrogen atom (Pryor 2000). Vitamin C is water soluble antioxidant that works in aqueous environment. Its main function is protect thiol groups of proteins. Vitamin $\mathrm{C}$ works with vitamin 
E, carotenoids, and enzymatic antioxidants (Uttara et al. 2009). Reduced glutathione (GSH) is a tripeptide and a multifunction antioxidant, it regenerates vitamin $\mathrm{C}$ and vitamin $\mathrm{E}$ back to their original form. Ubiquinone or Coenzyme $\mathrm{Q}$, also known as $(\mathrm{Q} 10, \mathrm{CoQ} 10$, and $\mathrm{CoQ})$, are present in mitochondria and inhibits lipid peroxidation.

\subsection{Oxidative stress and obesity}

Obesity means having excess body fat stored in tissues such as adipose tissue and liver (Indel et al. 2010) that result in adverse health effects. Obesity can be a result of intake of high energy food combined with low energy expenditure (Thompson et al. ). Excess fat storage causes insulin resistance; insulin resistance can stimulate inflammation (Indel et al. 2010). BMI (body mass index) is an important sign to one's overall health, when BMI is above $30 \mathrm{~kg} / \mathrm{m}^{2}$; person is at risk for type 2 diabetes, high blood pressure, heart disease, and other diseases. At least 6 out of 10 diseases leading to death are associated with obesity (Thompson et al. ). Obesity is a rising concern facing by develop and non-developing countries. Therefore the health care system will have to deal with diseases associated with obesity. Diabetes, hyperlipidaemia, hypertension, and atherosclerosis are associated with obesity. Obesity is a central component among patients that have metabolic syndrome, however not all of them are obese, even lean people have metabolic syndrome (Ando and Fujita 2009).

Researchers have found that increase in oxidative stress in accumulated fat is linked to the pathogenic mechanism of obesity and obesity associated metabolic syndrome such as inflammation, hypertension, and impaired glucose intake in muscle and fat (Décordé $\mathrm{K}$ et al. 2009). In general obesity is associated with reduced antioxidant defenses and/or a strong free radical production. The activity of antioxidant enzymes such as catalase, glutathione peroxidase, 
and glutathione reductase was lower in tissues and blood in some obese human and animal studies (Furukawa et al. 2004). Adipocytokines (fat derived hormones) or adipokines, including TNF- $\alpha$, plasminogen activator inhibitor-1 (PAI-1), resistin, leptin, and adiponectin are dysregulated by oxidative stress in accumulated fat. This plays a role in the pathogenesis of obesity associated metabolic syndrome. Figure 13 is an illustration of increase of ROS in accumulated fat leading to metabolic syndrome. Increases of ROS in accumulate fat via NADPH oxidase and decrease of antioxidant enzymes, causes dysregulation in production of adipocytokines. Metabolic syndrome is associated with induced insulin resistance and ROS encourages insulin resistance (Furukawa et al. 2004).

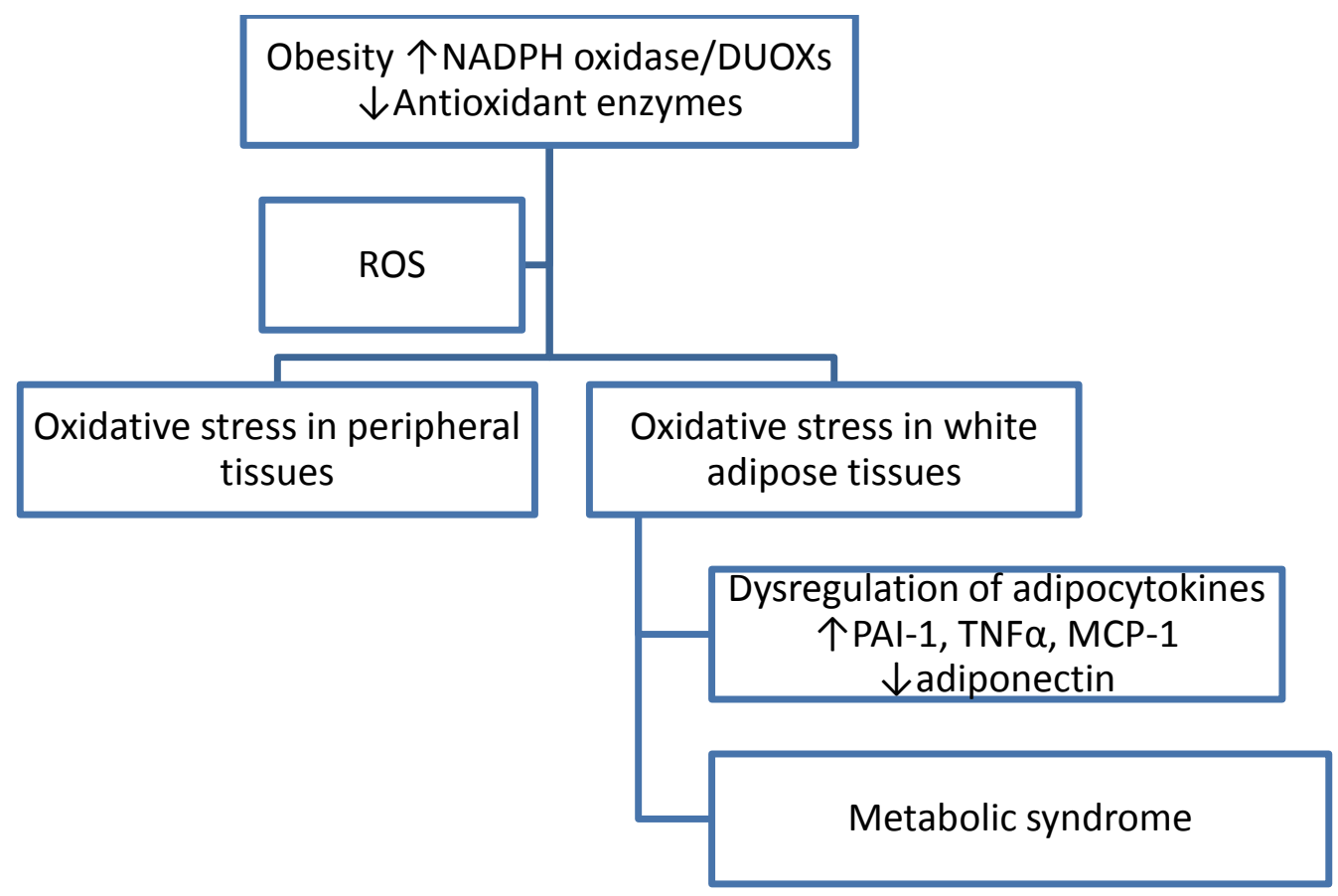

Figure 13: Illustration of the role of ROS in metabolic syndrome (Furukawa et al. 2004) 


\subsection{Study hypothesis and objectives}

Literature data clearly demonstrated that hydrolysis of food proteins with proteases, generates hydrolysates with antioxidant, anti-inflammatory, anti-hypertensive, anti-obesity or antimicrobial properties. Prior to the start of degree there was only one report of anti-hypertensive properties of digested oat proteins.

\subsubsection{Hypotheses}

My research hypotheses were:

a) Proteins extracted from oat under optimised conditions and digested with protease will show strong antioxidant activities in vitro

b) A hydrolysate with strong antioxidant activity added to high fat diet will decrease oxidative stress in an animal model

\subsubsection{Objectives}

i). Optimise extraction conditions of proteins from oat: Use of salts and carbohydrases

ii). Determine antioxidant properties of hydrolysates produced with various proteases. Determine the sequence of peptides using LC-MS/MS.

iii). Investigate the effect in vivo of some of the antioxidant hydrolysates on the reduction of oxidative stress in mice models receiving high fat diet.

iv). Measure in the mice model, body weight, glucose level, respiratory exchange ratio, total antioxidant capacity, activity of antioxidant enzymes, and vitamins. 


\section{Chapter 2}

Methodology 


\subsection{Method and Materials}

Oat flour and medium oat bran samples were obtained from Can Oat milling (Portage La Prairie, Manitoba MB). Linoleic acid, 2,2'-Diphenyl-1-picrylhydrazyl (DPPH), tocopherol, $\alpha$-tocopheryl, delta vitamin, $\alpha$-tocopheryl acetate (vitamin E acetate), gamma vitamin E, retinol, retinyl acetate, retinyl palmitate, acetate ferrozine, ethylenediaminetetraacetic (EDTA), ascorbic acid, Alcalase 2.4L (EC 3.4.21.14), trypsin (3.4.21.4), 6-hydroxy-2,5,7,8- tetramethylchroman-2-carboxylic acid (Trolox), 2,2'- azobis (2-amidinopropane) dihydrochloride (AAPH), mono- and dibasic potassium phosphates, Viscozyme L 100 Fungal Beta Glucanase (FBG)/g, a-amylase 30 units/mg, amyloglucosidase 70 units/mg, celluclast 700 Endo-Glucanase Units (EGU)/g, Alcalase 2.4 Anson Units (AU)/g, Trypsin 13,000-20,000 benzoyl-L-arginine ethyl ester units/mg, chloramine-T, potassium iodide, acetic acid, Tris-HCl, Trichloroacetic acid (TCA), 2,4-Dinitrophenylhydrazine (DNPH), thiourea, Copper(II) sulfate, Sulfuric acid $\left(\mathrm{H}_{2} \mathrm{SO}_{4}\right)$, were obtained from Sigma Aldrich (Oakville, ON, Canada). Methanol, ethanol, hexane, ethyl acetate, fluorescein, hydrogen peroxide $\left(\mathrm{H}_{2} \mathrm{O}_{2}\right)$, glutathione were purchased from Fisher Scientific Co. (Nepean, ON, Canada). High-purity water was produced in the laboratory by an Alpha-Q system (Millipore, Marlborough, MA). Nitrite/Nitrate assay kit was purchased from Cayman Chemical Company (Ann Arbor, MI, USA).

\subsection{Defatting the oat flour}

Oat flour was defatted using hexane in ratio of $1: 3(\mathrm{~W}: \mathrm{V})$, the sample was stirred for 1 hour at room temperature, in an incubator shaker $(200 \mathrm{rpm})$ model G25 from New Brunswick (Edison, 
NJ, USA), and after the extract was filtered on Watman paper No1. The defatted oat flour was air dried under fume hoods overnight.

\subsection{Preparation of protein isolates}

Extraction with salt: Defatted oat flour was added to the solution of $1.0 \mathrm{M}$ of $\mathrm{NaCl}$, in the ratio of $1: 8$ (w:v), the $\mathrm{pH}$ was adjusted to 9.5 using $1.0 \mathrm{M} \mathrm{NaOH}$, the slurry was stirred for $30 \mathrm{~min}$ at room temperature. The sample was centrifuged at $5000 \mathrm{xg}$ for $25 \mathrm{~min}$ at $4^{\circ} \mathrm{C}$. The supernatant was collected and the $\mathrm{pH}$ of the supernatant was adjusted to 4.0 using $1.0 \mathrm{M} \mathrm{HCl}$. The precipitated protein was washed with $30 \mathrm{~mL}$ of $\mathrm{pH} 4.0$ water three times. The precipitates were dispersed in $15 \mathrm{~mL}$ of nanopure water, and the $\mathrm{pH}$ was adjusted to 7.0 with $0.1 \mathrm{M} \mathrm{NaOH}$ (Zhu et al. 2006b). The sample was freeze dried and the protein content was determined using Lowry assay (Markwell et al. 1978). The protein isolates was digested with trypsin and alcalase according to procedure in 2.4

For the animal study the oat protein isolates were digested with trypsin according to section 2.4.

Extraction in the presence of carbohydrases: Defatted medium oat brans (50 g each), was mixed with deionized water at ratio $1: 10(\mathrm{w} / \mathrm{v})$. The $\mathrm{pH}$ of the slurries was adjusted according to the carbohydrase being used: amylase $(\mathrm{pH}$ 6.25), Viscozyme $(\mathrm{pH} 4.1)$, Cellulase $(\mathrm{pH} 5.5)$, Amyloglucosidase ( $\mathrm{pH}$ 5.5), and the control sample (no carbohydrase, $\mathrm{pH}$ 6.5). Concentrations of the enzymes were as follows: Amylase (60,2300 unit/ $g$ defatted brain), Celluclase EGU (5, 30, 60 unit/ $\mathrm{g}$ defatted brain), Viscozyme FBG (1.5, 3, 15 unit/ g defatted brain), and Amyloglucosidase units $(8,50,100$ unit/g defatted brain). All the slurries were incubated for 3.5 hours at $200 \mathrm{rpm}$ on New Brunswick incubator shaker, Model G25 (Edison, NJ, USA), $45{ }^{\circ} \mathrm{C}$. At the end of the incubation, the $\mathrm{pH}$ of the slurries were adjusted to 9.5 with $2 \mathrm{M} \mathrm{NaOH}$. Samples 
were further incubated for $30 \mathrm{~min}$, and were centrifuged at $4^{\circ} \mathrm{C}, 20 \mathrm{~min}$ at $2500 \mathrm{~g}$. Supernatants were collected, adjusted to $\mathrm{pH} 4$, and were centrifuged at $10,000 \mathrm{~g}, 40 \mathrm{~min}$ at $4^{\circ} \mathrm{C}$. The precipitates (i.e. protein isolates) were washed with $\mathrm{pH} 4$ water and were centrifuged $30 \mathrm{~min}$ at $1100 \mathrm{~g}$. Isolates were dissolved in water and the $\mathrm{pH}$ was adjusted to 7.0. Protein samples were freeze-dried and protein contents were determined using Lowry method (Markwell et al. 1978). These isolates were digested with alcalase according to procedure in section 2.4.

FBG: Fungal Beta-Glucanase Units; EGU: Endo-Glucanase Units

\subsection{Digestion of protein isolate with trypsin and alcalase}

\subsubsection{Alcalase hydrolysis:}

$\mathrm{NaCl}$ extracted protein isolates were dissolved in Milli-Q water (300 $\mathrm{mg}$ in $20 \mathrm{~mL}), \mathrm{pH}$ was adjusted to 8.0, the alcalase was added at an enzyme substrate ratio of 0.4 Anson Unit (AU)/g of

protein. For carbohydrase-treated brans (chapter 4), proteins were solubilized in water 1/10 (w/v) ratios and alcalase was added at an enzyme substrate ratio of 0.4 Anson Unit (AU)/g of protein. Samples were incubated at $50^{\circ} \mathrm{C}$ for $4 \mathrm{hrs}$, and the hydrolysis was stopped by heating the sample to $90^{\circ} \mathrm{C}$ for $10 \mathrm{~min}$. Supernatants were collected by centrifugation at $4000 \mathrm{~g}, 15 \mathrm{~min}$ and were freeze-dried and were stored at $20^{\circ} \mathrm{C}$ for further analyses.

\subsubsection{Trypsin hydrolysis:}

Enzymatic hydrolysis of $\mathrm{NaCl}$ extracted proteins was performed at $\mathrm{pH} 8.0$ deionized water (1:10 $(\mathrm{w} / \mathrm{v}))$ with trypsin at a substrate/enzyme ratio of $1: 50(\mathrm{w} / \mathrm{w})$. The sample was incubated at $37^{\circ} \mathrm{C}$ with shaking at $100 \mathrm{rpm}$ for $20 \mathrm{hrs}$. Samples were heated and supernatants collected as above. 
For in vitro assay studies (chapter 3), $300 \mathrm{mg}$ were hydrolyzed. For animal experiments a total of $40.96 \mathrm{~g}$ of freeze dried hydrolysates were obtained from $78.46 \mathrm{~g}$ of proteins.

Membrane ultra-filtration: To investigate the in vitro antioxidant activity of alcalase (APH) and trypsin ( $\mathrm{TPH}$ ) hydrolysates from $\mathrm{NaCl}$ extracted proteins (chapter 3), freeze dried samples were reconstituted in water, and were ultra-filtered on 2 and $10 \mathrm{kDa}$ molecular weight cutoff Vivaspin ${ }^{\mathrm{TM}}$ 15R membrane from VWR Canada (Mississauga, ON). The samples then were freeze dried and were stored at $-20^{\circ} \mathrm{C}$.

Amino acid analysis: The amino acid (AA) composition of the freeze dried of trypsin hydrolysate used for animal study (chapter 5) was performed by Advanced Protein Technology Centre at the Hospital for Sick Children, Ontario, Canada. Picomoles of individual amino acids detected were converted to percentage relative to total amino acids content.

\subsection{DPPH radical scavenging effect}

The scavenging effects of both alcalase protein hydrolysates (APH), trypsin protein hydrolysates $(\mathrm{TPH})$, and the ultra-filtered fractions $(2 \mathrm{kDa}, 2-10 \mathrm{kDa}$ and $>10 \mathrm{kDa})$ were measured using $60 \mu \mathrm{mol} / \mathrm{L}$ DPPH solution freshly prepared in $100 \%$ methanol. Sample concentrations of 0.4 and $1 \mathrm{mg} / \mathrm{mL}$ in Milli-Q water was reacted with DPPH solution (final concentration 0.08 and 0.2 $\mathrm{mg} / \mathrm{mL}$ ) for $15,30,45$, and $60 \mathrm{~min}$. The samples were read at $515 \mathrm{~nm}$ with spectrophotometer (Gary 300 UV-Visible Spectrophotometer, Varian Inc, Australia) against a blank of $100 \%$ methanol. Samples were run in triplicates, and the \% Scavenging activity was calculated as follows (Li et al. 2008):

$$
\% \text { Scavenging activity }=\left(1-\frac{A s}{A C T L}\right) \times 100
$$

As is the absorbance at time $t$ and ACTL is the absorbance of control (DPPH) at time zero. 


\subsection{Oxygen radical absorbance assay of digested oat flour proteins}

Peroxyl radical scavenging activity was determined using oxygen radical absorbance capacity (ORAC) assay. The measurement was done on a microplate fluorescence reader model FLx800 (Bio-Tek Instruments, Inc., Winooski, VT), this instrument is equipped with a temperaturecontrolled incubation chamber and with fluorescence filters (excitation $485 / 20 \mathrm{~nm}$, emission $528 / 20 \mathrm{~nm})$. Incubator temperature was set at $37^{\circ} \mathrm{C}$. Potassium phosphate buffer $(75 \mathrm{mM} / \mathrm{L}, \mathrm{pH}$ 7.4) was used to prepare all the reagents, standards, samples, and the control. Trolox was used as a standard and the concentrations prepared were $6.25,12.5,25,50$ and $100 \mu \mathrm{M}$. Rutin was used as control. The data were processed with Gen5 software.

For in vitro experiments, $\mathrm{PH}, \mathrm{TPH}$ and $\mathrm{APH}$ were analyzed at 160 and $80 \mu \mathrm{g} / \mathrm{mL}$, hydrolysates from carbohydrase treated barns were analyzed at 0.0025 and $0.00125 \mu \mathrm{g} / \mathrm{mL}$.

Mice samples: Red blood cells were diluted 1600 times, and plasma samples were diluted 200X. For liver samples concentrations of $0.001 \mathrm{mg} / \mu \mathrm{L}$, and for brain samples concentration of $0.004 \mathrm{mg} / \mu \mathrm{L}$ was used.

The results were expressed as $\mu$ mol Trolox Equivalents (TE) and are means \pm SEM (Zulueta et al. 2009b). All the samples and standards were done in triplicates.

\subsection{Measurement of ferrous ion-chelating activity}

Protein hydrolysates were prepared in concentrations of 20, 40, 80, 120 and $200 \mu \mathrm{g} / \mathrm{mL}$ in MilliQ water, and ultra-filtered fractions $(2 \mathrm{kDa}, 2-10 \mathrm{kDa}$, and $>10 \mathrm{kDa})$ from trypsin and alcalase digests were prepared. $2 \mathrm{mmol} / \mathrm{L}$ of $\mathrm{FeCl}_{2}$ freshly prepared was added to all the samples. The reactions was initiated by addition of $5 \mathrm{mmol} / \mathrm{L}$ aqueous ferrozine solution and the mixture was 
shaken vigorously and left at room temperature for $10 \mathrm{~min}$. The absorbance was read at $562 \mathrm{~nm}$ by the spectrophotometer. EDTA was used for positive control (Dinis,T,C,P. et al. 1994). The \% Inhibition of ferrozine- $\mathrm{Fe}^{2+}$ complex formation was calculated as follows Ferrous ion chelating

$$
\text { activity }=\left(1-\frac{\mathrm{A} 1-\mathrm{ABlk}}{\mathrm{A} 0}\right) \times 100
$$

$\mathrm{A}_{0}$ is the absorbance of the control $\left(\mathrm{FeCl}_{2}\right.$ and ferrozine)

$A_{1}$ is the absorbance in the presence of samples

$\mathrm{ABlk}$ is the absorbance of sample blank without $\mathrm{FeCl}_{2}$

\subsection{Inhibition of linoleic acid autoxidation}

APH and TPH antioxidative activity were measured in different incubation periods. This measurement was done with linoleic acid model, as follows: $0.8 \mathrm{mg} / \mathrm{mL}$ of TPH and APH was prepared in $50 \mathrm{mmol} / \mathrm{L}$ phosphate buffer ( $\mathrm{pH} 7.0)$, this was added to a solution that was made of linoleic acid and $99.5 \%$ ethanol in ratio of (30:2500), and the final concentration was $0.4 \mathrm{mg} / \mathrm{mL}$. This mixture was incubated at $50^{\circ} \mathrm{C}$ in dark, in a screw cap. The degree of oxidation was measured by measuring the ferric thiocyanate values (Sakanaka et al. 2004). The reaction solution was then mixed with $75 \%$ ethanol, $30 \%$ ammonium thiocyanate and $0.02 \mathrm{~mol} / \mathrm{L}$ ferrous chloride solution in $3.5 \% \mathrm{HCl}$ in a ratio of 50: 2.35:50:50 respectively. The sample was incubated for $10 \mathrm{~min}$ and the absorbance was measured at $500 \mathrm{~nm}$ at different intervals during 5 days. $\alpha$-tocopherol was used as control.

\subsection{Hydroxyl radical (HO•) scavenging assay}

The alcalase hydrolyzed from carbohydrase treated bran proteins were all analyzed at $1 \mathrm{mg} / \mathrm{mL}$, glutathione, an endogenous antioxidant peptide was used as positive control. All samples were 
prepared in $0.75 \mathrm{mmol} / \mathrm{L}$ potassium phosphate buffer $(\mathrm{pH} 7.4)$. Each sample was mixed with 3 mmol/L 1,10-phenanthroline (1:1 ratio) in phosphate buffer, and $3 \mathrm{mmol} / \mathrm{L} \mathrm{FeSO}_{4} \cdot 7 \mathrm{H}_{2} \mathrm{O}$ in water. The reaction was initiated by addition of $0.03 \%$ aqueous $\mathrm{H}_{2} \mathrm{O}_{2}$, and then was incubated at $37^{\circ} \mathrm{C}$ for 1 hour with shaking at $200 \mathrm{rpm}$ on a Max-Q 4500 incubator (Fisher Scientific Canada, Nepean, ON). The absorbance of the samples were read at $536 \mathrm{~nm}$ using a Cary 50 Bio UV-vis spectrophotometer controlled by CaryWinUV Bio Pack Software (Varian Inc., Mississauga, $\mathrm{ON}$ ). The absorbance of the blank (without sample and $\mathrm{H}_{2} \mathrm{O}_{2}$ ) was also determined. Everything was done in triplicates. The $\mathrm{HO} \cdot$ scavenging activity was calculated according to the literature (Li et al. 2008). This method was modified from a procedure from the literature (Pownall et al. 2010).

\subsection{NanoLC tandem mass spectrometry}

The samples were injected in to a $7 \mathrm{~cm} \times 200 \mu \mathrm{m}$ inner diameter trap column, fritted, and packed in-house with $5 \mathrm{~cm}$ of $3 \mu \mathrm{m}$ Magic C18AQ reversed phase packing material (Michrom Bioresources, Auburn, CA) using a pressure vessel constructed in house. The samples were at 1 $\mathrm{mg} / \mathrm{mL}$ in $2 \%$ acetic acid. The trap column was connected in series to a $6 \mathrm{~cm} \times 75 \mu \mathrm{m}$ Picofrit analytical column with a tip opening of $15 \mu \mathrm{m}$ (New Objective, Woburn, MA), packed with $5 \mathrm{~cm}$ of $3 \mu \mathrm{m}$ Magic C18AQ reversed phase packing material. Peptides were separated using a gradient of $2 \% \mathrm{~B}$ at $0 \mathrm{~min}, 5 \% \mathrm{~B}$ at $3 \mathrm{~min}, 10 \% \mathrm{~B}$ at $8 \mathrm{~min}, 29 \% \mathrm{~B}$ at $70 \mathrm{~min}, 80 \% \mathrm{~B}$ at $75 \mathrm{~min}$ and after the samples were washed for 10 min with $100 \% \mathrm{~B}$ and 5 min of re-equilibration at $2 \% \mathrm{~B}$, where $\mathrm{A}$ and $\mathrm{B}$ are $0.1 \%$ formic acid/water and $0.1 \%$ formic acid/acetonitrile, respectively. Peptides were eluted from the trap and analytical columns at a flow rate of $\sim 250 \mathrm{~nL} / \mathrm{min}$, ionized by nanoelectrospray ionization (ESI) and analyzed using a QSTAR XL QqTOF mass spectrometer 
(AB Sciex, Concord, ON) operating in information dependent acquisition mode over a mass range of 400 to $1500 \mathrm{~m} / \mathrm{z}$. For fragmentation ions with a charge state of $2^{+}$and $3^{+}$were chosen. The analysis was done on the most intense peaks in the spectrum, one 1-s, two 2-s, and two 3-s tandem mass spectrometric. Masses are sequenced two times before adding them to an exclusion list for $90 \mathrm{~s}$.

MS/MS data were determined using Mascot (Matrix Science Ltd, Boston, MA). Mass tolerances were set to $\pm 100 \mathrm{ppm}$ and $\pm 0.2 \mathrm{Da}$ for the peptide and fragment ion spectra, respectively. Peptides identified by Mascot were manually examined and verified for accuracy. Peptide sequences were matched to the published sequences of all proteins from the National Center for Biotechnology Information non-redundant database (NCBInr). ; One missed cleavage was considered; no modification was selected.

\subsection{Animals and diet}

The current study protocol was approved by the Carleton University's Animal Care Committee (Protocol number P10-4) and followed guidelines of the Canadian Council on Animal Care.

Fifty two CD-1 male mice were obtained from Charles River Laboratories in Saint Constant, Quebec, 8 weeks old, 20-25 g. Each mice had its own cage, and were kept at room temperature $22^{\circ} \mathrm{C}$ with $20 \%$ relative humidity and $12 / 12 \mathrm{hr}$ light/dark cycle. Lights were on at 7:00am, during the study. OPH or Oat protein isolated digested with trypsin was prepared according to section 2.3. The animals were fed the normal chow diet in pelletized form for 4 weeks. After this four weeks, each mice was assigned to one of five groups, each group had 10 mice $(n=10)$. The five different groups are: Group 1 is High fat diet (HF); Group 2 is $\mathrm{HF}+1 \mathrm{mg}$ of oat protein hydrolysate $(\mathrm{OPH}) / \mathrm{g}$ of HF; Group 3 is $\mathrm{HF}+10 \mathrm{mg} \mathrm{OPH} / \mathrm{g}$ of HF; Group 4 is $\mathrm{HF}+100 \mathrm{mg}$ 
$\mathrm{OPH} / \mathrm{g}$ of $\mathrm{HF}$ and Group 5 is normal diet (ND) or regular mouse chow. The group division is summarized in figure 14. The $\mathrm{OPH}$ was blended with the high fat diet in the mixer. The animals received this diet for three weeks ad libitum. Animals had free access to food and water. The normal diet was 2014 Teklad Global $2.9 \mathrm{Kcal} / \mathrm{g}$ and the HF diet was $5.1 \mathrm{Kcal} / \mathrm{g}$. These diets were purchased from Teklad Harlan (Indianapolis, IN). The diet composition is summarized in table 1. The high fat diet composition is summarized in table 2, and table 3 shows the vitamin mix in the high fat diet. The high fat diet was based on the AIN-93-VX diet (Reeves 1997).

Body weight and food intake were recorded daily, and the caloric intake calculated based on food consumed. At the end of the three weeks, 30 animals $(n=6)$, were rapidly decapitated. The tissues were rapidly frozen with liquid nitrogen. Twenty animals $(n=4)$ were housed in metabolic chambers (TSE systems, Chesterfield, MO, USA) for 48 hours. Animals had free access to food and water. The locomotor activity was determined using multi-dimensional infrared light beam system, and the respiratory exchange rate (RER) was calculated based on the oxygen consumption, and production of carbon dioxide. Blood samples were collected into heparincoated tubes following decapitation. Then, all blood samples were centrifuged at $1000 \times \mathrm{g}$ for 15 min at $4{ }^{\circ} \mathrm{C}$ to obtain plasma and red blood cells. Glucose level was determined using Accucheck ${ }^{\circledR}$ glucose meter. Liver, lung, brain, muscle and heart samples were removed, rapidly frozen. All tissues were rapidly frozen in liquid nitrogen and stored at $-80{ }^{\circ} \mathrm{C}$ until analysis. The procedure was standardized for all tissues to avoid hemoglobin oxidation and alteration of enzyme activities. For analysis the tissue samples were homogenized at concentration of $0.1 \mathrm{mg} / \mathrm{mL}$ with $10 \mathrm{mM}$ phosphate buffer $\mathrm{pH}$ 7.4. 


\begin{tabular}{|l|l|l|l|l|l|}
\hline Content & HF & HF $+1 \mathrm{mg}$ & $\mathrm{HF}+10 \mathrm{mg}$ & $\mathrm{HF}+100 \mathrm{mg}$ & Normal Diet \\
OPH $/ \mathrm{g}$ food & $\mathrm{OPH} / \mathrm{g}$ food & OPH/g food & \\
\hline$\%$ Protein & 23.5 & 23.5 & 23.5 & 23.5 & 14.0 \\
\hline$\%$ Fat & 34.3 & 34.3 & 34.3 & 34.3 & 4 \\
\hline $\begin{array}{l}\text { Energy } \\
\mathrm{kCal} / \mathrm{g}\end{array}$ & 5.100 & 5.104 & 5.140 & 5.500 & 2.9 \\
\hline $\begin{array}{l}\text { Protein } \\
\text { hydrolysate }\end{array}$ & $\begin{array}{l}0 \quad \mathrm{mg} / \mathrm{g} \\
\text { food }\end{array}$ & $1 \mathrm{mg} / \mathrm{g}$ food & $10 \mathrm{mg} / \mathrm{g}$ food & $100 \mathrm{mg} / \mathrm{g}$ food & $0 \mathrm{mg} / \mathrm{g}$ food \\
\hline
\end{tabular}

Table 1: Summary of the composition of normal, high fat (HF) and experimental (HF + hydrolysate) diets. Normal and high fat diets were purchased from Teklad Harlan (Indianapolis, $\mathrm{IN})$ 


\begin{tabular}{|l|l|}
\hline Content & g/Kg \\
\hline Casein & 265.0 \\
\hline L-Cystine & 4.0 \\
\hline Maltodextrin & 160.0 \\
\hline Sucrose & 90.0 \\
\hline Lard & 310.0 \\
\hline Soybean Oil & 30.0 \\
\hline Cellulose & 65.5 \\
\hline Mineral Mix, AIN-93G-MX (94046) & 48.0 \\
\hline Calcium Phosphate, dibasic & 3.4 \\
\hline Vitamin Mix, AIN-93-VX (94047) & 21.0 \\
\hline Choline Bitartrate & 3.0 \\
\hline Blue Food Color & 0.1 \\
\hline
\end{tabular}

Table 2: Composition of high fat diet 


\begin{tabular}{|l|l|}
\hline Formula & g/Kg \\
\hline Niacin & 3.0 \\
\hline Calcium Pantothenate & 1.6 \\
\hline Pyridoxine HCl & 0.7 \\
\hline Thiamin HCl & 0.6 \\
\hline Riboflavin & 0.6 \\
\hline Folic Acid & 0.2 \\
\hline Biotin & 0.02 \\
\hline Vitamin B12 (0.1\% in mannitol) & 2.5 \\
\hline Vitamin E, DL-alpha tocopheryl acetate (500 & 15.0 \\
\hline IU/g) & 0.07 \\
\hline Vitamin A Palmitate (500,000 IU/g) & 0.8 \\
\hline Vitamin D3, cholecalciferol (500,000 IU/g) & 0.2 \\
\hline Vitamin K1, phylloquinone & 974.705 \\
\hline Sucrose, fine ground & \\
\hline
\end{tabular}

Table 3: Concentration of vitamins in the high fat diet 


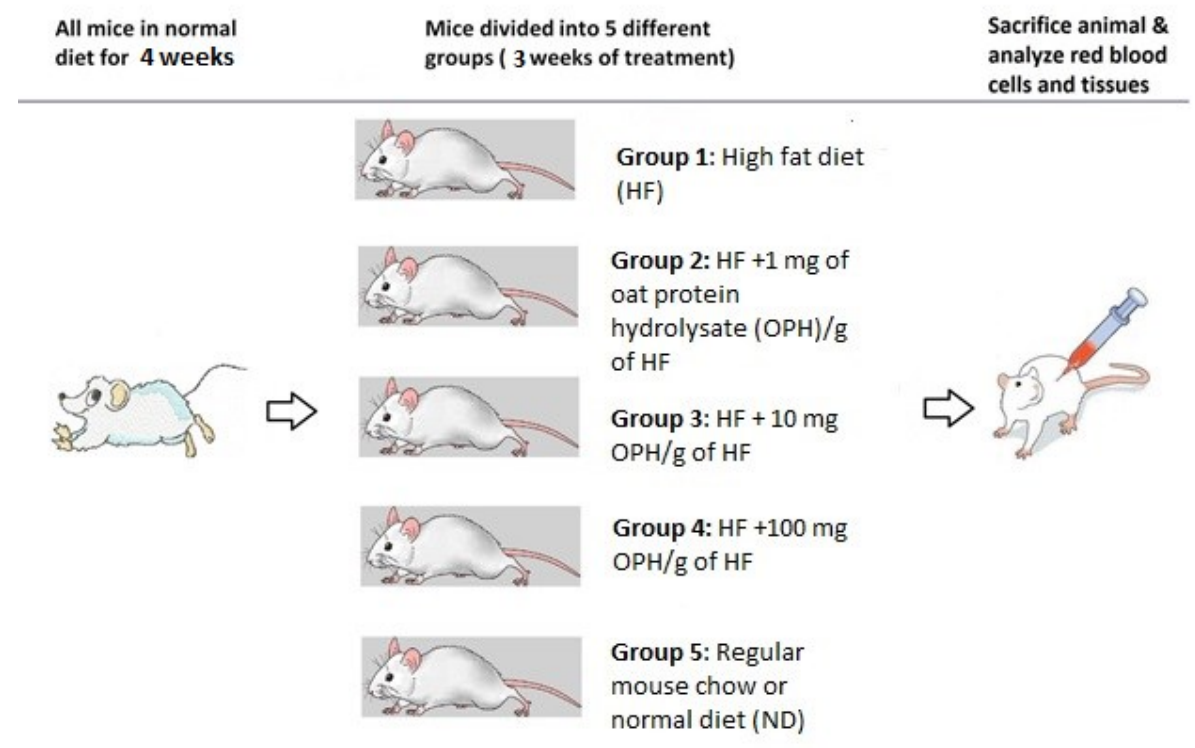

Figure 14: Different groups of CD1 mice. Group1 is High fat diet (HF); Group 2, is HF + 1mg of oat protein hydrolysate (OPH)/g of HF; Group 3, is HF + $10 \mathrm{mg} \mathrm{OPH/g} \mathrm{of} \mathrm{HF;} \mathrm{Group} \mathrm{4,} \mathrm{HF} \mathrm{+}$ $100 \mathrm{mg} \mathrm{OPH} / \mathrm{g}$ of HF and Group 5, regular mouse chow or normal diet (ND).

\subsection{Total thiols}

Total thiols were measured using Ellman's method, this method is based on a colorimetric reaction between the sulfhydryl groups with DTNB (5,5-dithiobtis-2 nitro benzoic acid) forming a yellow compound, detected at $412 \mathrm{~nm}$ (Avinash et al. 2009). Tissue samples were homogenized with phosphate buffer $\mathrm{pH} 7.4(1: 10 \mathrm{w} / \mathrm{v})$ and centrifuged at $5000 \mathrm{~g}$ while plasma was diluted 10 times with buffer prior to measurement as reported in literature (Lushchak and Bagnyukova 2006; Ellman 1959). 


\subsection{Ferrous oxide xylenol (FOX) orange assay}

Peroxides were analyzed by ferrous oxide xylenol (FOX) orange assay on blood and liver samples according to a previously published method (Smith et al. 2002). Briefly, FOX reagent was made by adding one volume of a mixture of xylenol orange $(1.0 \mathrm{mM})$ and ammonium ferrous sulfate $(2.5 \mathrm{mM})$ in $250 \mathrm{mM} \mathrm{H}_{2} \mathrm{SO}_{4}$ to nine volumes of $4.4 \mathrm{mM}$ BHT prepared in methanol. Eight concentrations of $\mathrm{H}_{2} \mathrm{O}_{2}$ standards $(5-200 \mu \mathrm{M})$ were made from $30 \% \mathrm{H}_{2} \mathrm{O}_{2}$ stock solution. FOX reagent was mixed with all samples and standards (in ratio of 1140:60), followed by incubation for $30 \mathrm{~min}$ at room temperature and were read at absorbance of $560 \mathrm{~nm}$. The peroxide concentrations were calculated based on the calibration curve and expressed as nano moles of $\mathrm{H}_{2} \mathrm{O}_{2}$ per gram of wet weight.

\subsection{Determination of superoxide dismutase and catalase activities}

Liver tissues extracts for enzyme activity were prepared by homogenization $(1: 9(\mathrm{w} / \mathrm{v}))$ in potassium phosphate buffer $(10 \mathrm{mM} \mathrm{pH} 7.4)$ and centrifugation at $2400 \mathrm{~g}$ for $10 \mathrm{~min}$. Red blood cells (RBC) and liver samples were aliquoted into $100 \mu \mathrm{L}$ microtubes and stored in $-80{ }^{\circ} \mathrm{C}$ until analysis.

Protein content of the liver and RBCs were determined using a modified Lowry's method (Markwell et al. 1978).

Superoxide dismutase (SOD) activity was measured based on the rate of reduction of nitroblue tetrazolium $(2.24 \mathrm{mM})$ to formazan by xanthine oxidase $(13.2 \mathrm{U} / \mathrm{mL}$ ) at $560 \mathrm{~nm}$ (Spitz et al. 1989). Eight different concentrations of each sample (2 to $500 \mathrm{mg}$ protein $/ \mathrm{mL}$ ) were used. SOD activities were calculated and expressed as units per milligram of protein. Catalase (CAT) activity was performed according to the method described by Aebi (Aebi H, 1984). The activity 
was based on the decay of a $30 \mathrm{mM} \mathrm{H}_{2} \mathrm{O}_{2}$ at $240 \mathrm{~nm}$ and expressed as $\mathrm{k} / \mathrm{mg}$ protein where $\mathrm{k}$ is the first order reaction constant.

\subsection{Determination of advanced oxidation protein products (AOPPs)}

The brain, heart and liver tissues were homogenized in $0.1 \mathrm{M}$ Tris- $\mathrm{HCl}$ and centrifuged at $2400 \mathrm{xg}$ for $10 \mathrm{~min}$, and the supernatant was collected. Determination of advanced oxidation protein products (AOPPs) in plasma, brain, heart, liver was based on spectrophotometric detection according to Witko-Sarsat et al. Tissue samples were prepared at concentration of $0.01 \mu \mathrm{g} / \mathrm{mL}$ with $20 \mathrm{mM}$ phosphate buffer, $\mathrm{pH} 7.4$, and plasma samples were diluted 40 times with phosphate buffer. Chloramine-T was used as standard, and was prepared in concentrations, 100, 80, 60, 40, 20, 10, 5, $0 \mu \mathrm{M}$. Phosphate buffered saline was used as blank. $1.16 \mathrm{~mol} \mathrm{~L} / 1$ potassium iodide was added to all samples, standards and blank in 1:20 ratio. The plate was incubated at room temperature for 5 minutes, and $20 \mu \mathrm{L}$ of acetic acid were added making the final volume of the assay medium to $230 \mu \mathrm{L}$, absorbance was measured immediately at $340 \mathrm{~nm}$. Concentration of AOPPs was expressed as $\mu$ mol L-1 of chloramine-T equivalents.

\subsection{Nitrite/Nitrate assay}

The Heart and Brain tissues were homogenized in $0.1 \mathrm{M}$ Tris- $\mathrm{HCl}$ and centrifuged at $2400 \mathrm{xg}$ for $10 \mathrm{~min}$. The liver tissues were homogenized 1:9(w/v) in potassium phosphate buffer $(10 \mathrm{mM} \mathrm{pH}$ 7.4) and centrifuged at $2400 \mathrm{xg}$ for $10 \mathrm{~min}$. The supernatant was collected and formation of NO (nitrite + Nitrate) was detected in tissues using a colorimetric assay kit from Cayman Chemical Company, Ann Arbor, MI, USA). Concentrations were calculated by using nitrite standards, and the results were expressed as $\mu \mathrm{mol} / \mathrm{g}$ of tissue. 


\subsection{Vitamin C}

Vitamin $\mathrm{C}$ was measured in liver, brain, and lung. L-ascorbic was used as standard, and were prepared in concentrations $0,3.125,6.25,12.5,25,50$ and $100 \mu \mathrm{g} / \mathrm{mL}$. Hundred $\mathrm{mg}$ of the tissue was homogenized in $400 \mu \mathrm{L}$ of $0.01 \mathrm{M}$ phosphate buffer $\mathrm{pH} 7.0$. Five hundred $\mu \mathrm{L}$ of the $10 \%$ TCA was added to the samples and were centrifuged at $3500 \mathrm{xg}$ for 20 minutes. Samples and standard were prepared in triplicates. Two hundred fifty $\mu \mathrm{L}$ of the supernatant was mixed with $100 \mu \mathrm{L}$ of DTC solution ( $0.75 \mathrm{~g}$ of DNPH, $0.1 \mathrm{~g}$ thiourea and $0.0125 \mathrm{~g} \mathrm{CuSO}_{4}$ in $\left.9 \mathrm{~N} \mathrm{H}_{2} \mathrm{SO}_{4}\right)$. Samples and standards were incubated at $37^{\circ} \mathrm{C}$ for 3 hours. After samples and standards were mixed with $750 \mu \mathrm{L}$ of ice cold $65 \% \mathrm{H}_{2} \mathrm{SO}_{4}$, and were incubated for 30 minutes at room temperature. Samples and standards were read with microplate reader at $520 \mathrm{~nm}$ absorbance and data were analyzed using Gen5 ${ }^{\text {TM }} 2.0$ software.

\subsection{Determination of vitamin $A$ and $E$ in liver, lung and brain by HPLC}

The reagents used are, methanol 100\% HPLC grade, ethanol 100\% HPLC grade, ethanol 95\%, $\alpha$ tocopherol, $\alpha$-tocopheryl acetate, delta vitamin, gamma vitamin E, retinol, retinyl acetate, retinyl palmitate, ethyl acetate. The HPLC system consisted of a binary pump (Waters model 1525), an

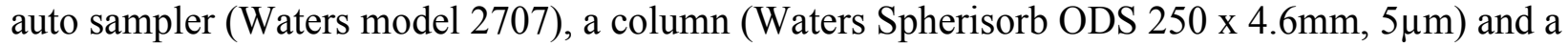
Photodiode Array Detector set at 292 nm (Waters model 2998). The mobile phase used was $100 \%$ methanol at a flow rate of $1 \mathrm{~mL} / \mathrm{min}$. The column was maintained at room temperature and the samples compartment was kept at $8^{\circ} \mathrm{C} .20 \mu \mathrm{L}$ of each sample was injected in triplicate and run for 35 minutes. Data were processed and analyzed using the Waters Empower 3 software. Stock solution were prepared in ethanol. Retinyl acetate $20 \mu \mathrm{g} / \mathrm{mL}$ : it was used as internal 
standard, Retinol (vitamin A): $100 \mu \mathrm{g} / \mathrm{mL}$, Retinyl palmitate (vitamin A palmitate): $100 \mu \mathrm{g} / \mathrm{mL}$, $\alpha$-tocopherol (vitamin E): $200 \mu \mathrm{g} / \mathrm{mL}, \alpha$-tocopheryl acetate (vitamin E acetate): $200 \mu \mathrm{g} / \mathrm{mL}$, Gamma vitamin E: $200 \mu \mathrm{g} / \mathrm{mL}$, Delta vitamin E: $200 \mu \mathrm{g} / \mathrm{mL}$. Each vitamin standard was run in the HPLC to find the retention time.

Tissue preparation: To $100-200 \mathrm{mg}$ of tissue was added to $0.7 \mathrm{~mL}$ of ethanol - water $(1: 1)$ and homogenized with a polytron ( $7 \mathrm{~mm}$ homogenizer). A $50 \mu 1$ of a $20 \mu \mathrm{g} / \mathrm{ml}$ retinyl acetate was added. The sample was centrifuged for $1 \mathrm{~min}$. In order to extract the vitamins, $0.7 \mathrm{~mL}$ of hexanes was added and the vial was vortex for $1 \mathrm{~min}$, and after the sample was centrifuged at $2400 \mathrm{rpm}$ for 10 minutes. The supernatant was separated, this step was repeated two times, and the supernatants were mixed and were dried with nitrogen gas at $35^{\circ} \mathrm{C}$. The residue was reconstituted with $500 \mu 1$ ethanol: ethyl acetate (3:1) and filtered through a $45 \mu \mathrm{m}$ filter into an HPLC vial insert for analysis

\section{Statistical evaluation}

All data are expressed as mean \pm standard error (SE). Comparisons between the groups was done using SPSS. Statistical differences were evaluated by a one-way ANOVA using SPSS 11.0 for windows 7 (SPSS Inc., Chicago). $\mathrm{P}<0.05$ was considered significantly different between the groups. Scatter plots from Microsoft Excel 2010 (Microsoft, Redmond, WA, USA) were used to obtain correlations between amounts of OPH added to high fat diet and actvities. 


\section{Chapter 3}

\section{Antioxidant activity of digested oat protein hydrolysates extracted in the presence of salts}




\section{Introduction}

In addition to their nutritional properties, food proteins have now been recognized as sources of peptides that can positively affect the functioning of the human body through various modes of action. Hydrolyzed proteins and peptides from cereals such wheat, corn and rice have been evaluated for their ability to reduce oxidative stress. Radical scavenging, metal chelating and inhibition of lipid peroxide formation have been reported for digested proteins from wheat germ (Cheng et al. 2006; Suetsuna and Chen 2002), while those from rice reduced atherosclerotic lesions in apoE-deficient mice through up-regulation of antioxidant enzymes (Burris et al. 2010). Pretreatment of mice with corn protein hydrolysates prevented lipopolysaccharide induced immunological and oxidative liver injury (Guo et al. 2009).

Oat (Avena sativa), is a popular cereal that has been associated with many health benefits including lower serum LDL-cholesterol in overweight males (Reyna-Villasmil et al. 2007) and healthy adults (Reyna-Villasmil et al. 2007) after consumption of bread and fruits enriched in oat beta-glucans. Other oat molecules such as avenanthramides have been shown to inhibit the secretion of proinflammatory cytokines interleukins IL-6 and IL-8 in endothelial cells (Guo et al. 2008). Oat also has good quality proteins because of higher content of the limiting amino acid lysine (Victor et al. 1977). The antioxidant properties of their peptides has not been investigated The objective of this chapter is therefore to determine the radical scavenging, metal chelating and inhibition of lipid peroxide formation by hydrolyzed oat proteins and their ultra-filtered fractions. 


\subsection{Results and Discussion}

Proteins were extracted with $\mathrm{NaCl}$ as described in section 2.2 and were then digested with trypsin (TPH) and alcalase (APH) to produce trypsin (TPH) and alcalase protein hydrolysates, respectively (see section 2.3 ). The hydrolysates were then ultra-filtered into $\leq 2,2-10$ and $\geq 10$ $\mathrm{kDa}$ fractions. Antioxidant activity of the each fraction was performed using DPPH, linoleic acid, ferrous ion-chelating, and oxygen radical absorbance capacity (ORAC) assays. The overall experimental design is summarized in figure 15 .

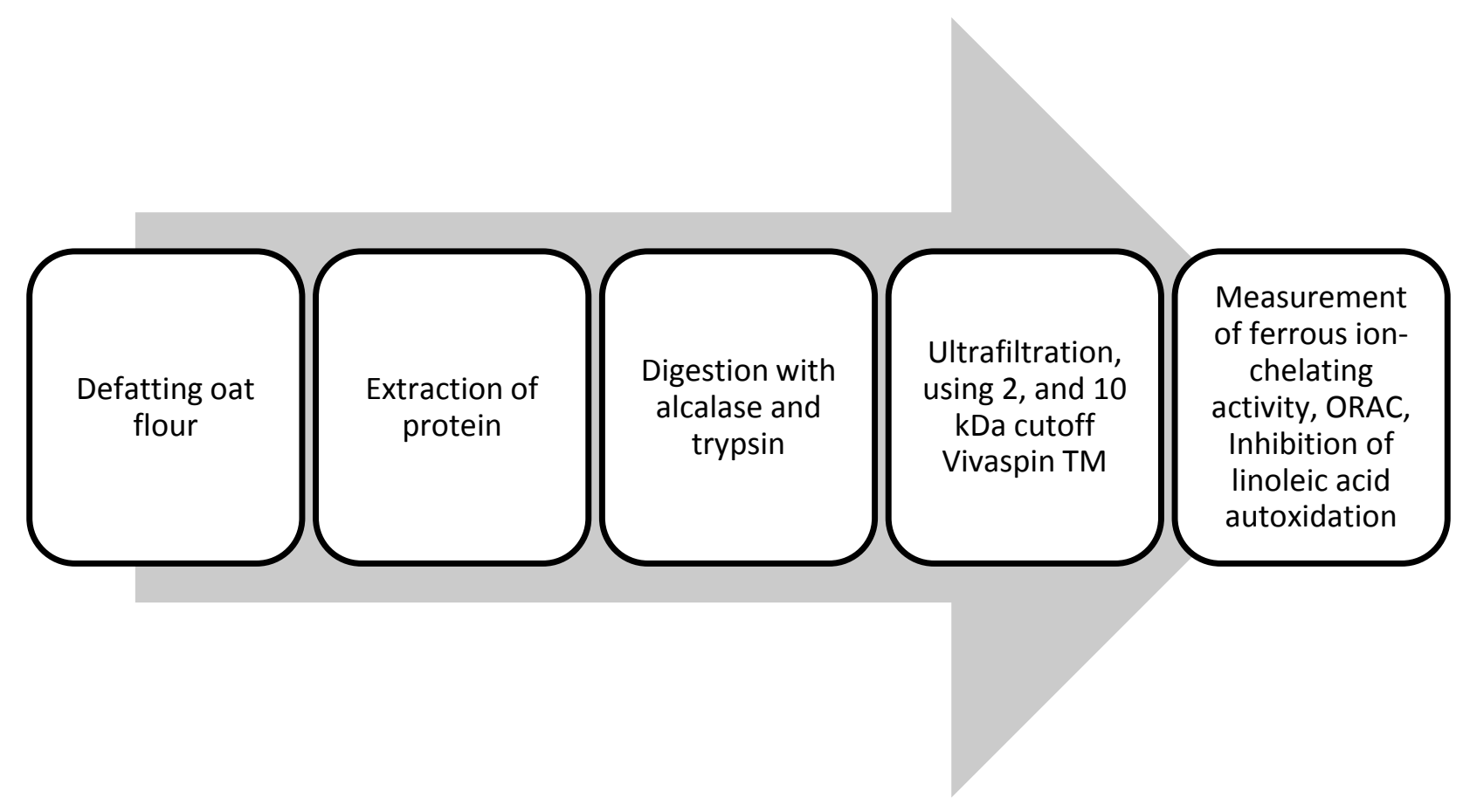

Figure 15: Summary of experiment procedures of work done in chapter 3 


\subsection{Scavenging activity of hydrolysates and fractions}

DPPH is a radical often used as a probe to test a molecule ability to scavenge free radicals and therefore its antioxidant activity. This probe was used to measure the ability of APH, TPH and their ultra-filtered fractions to act as antioxidants. The results are shown in Figure 16. The most active fraction was the Alcalase fraction $2 \mathrm{kDa}(\mathrm{APH} 2 \mathrm{kDa})$ with inhibition of 33 and $35 \%$ at 15 and $45 \mathrm{~min}$, respectively. TPH $2 \mathrm{kDa}$ inhibition was lower 20 and $32 \%$ at 15 and $45 \mathrm{~min}$. However at 60 min these two fractions had similar inhibition activity. Non-fractionated APH and TPH samples had similar activity $(\mathrm{p}>0.05)$ during the entire incubation period. The lowest scavenging activity belonged to $\mathrm{TPH}>10 \mathrm{kDa}$.

The scavenging activity was also determined using ORAC (Table 4), an assay that measure the scavenging activity of molecules against peroxyl radical and commonly used to determine antioxidant activity of food components (Tsopmo et al. 2009; Dávalos et al. 2004). The ORAC values were expressed as $\mu \mathrm{mol} / \mathrm{L}$ trolox equivalents per gram of sample. The ORAC value for TPH was $434 \pm 16$, and that of APH was $269 \pm 4$, these values were significantly different. The ORAC values for the ultra-filtered fractions, for TPH>2 kDa was $345 \pm 15$. 


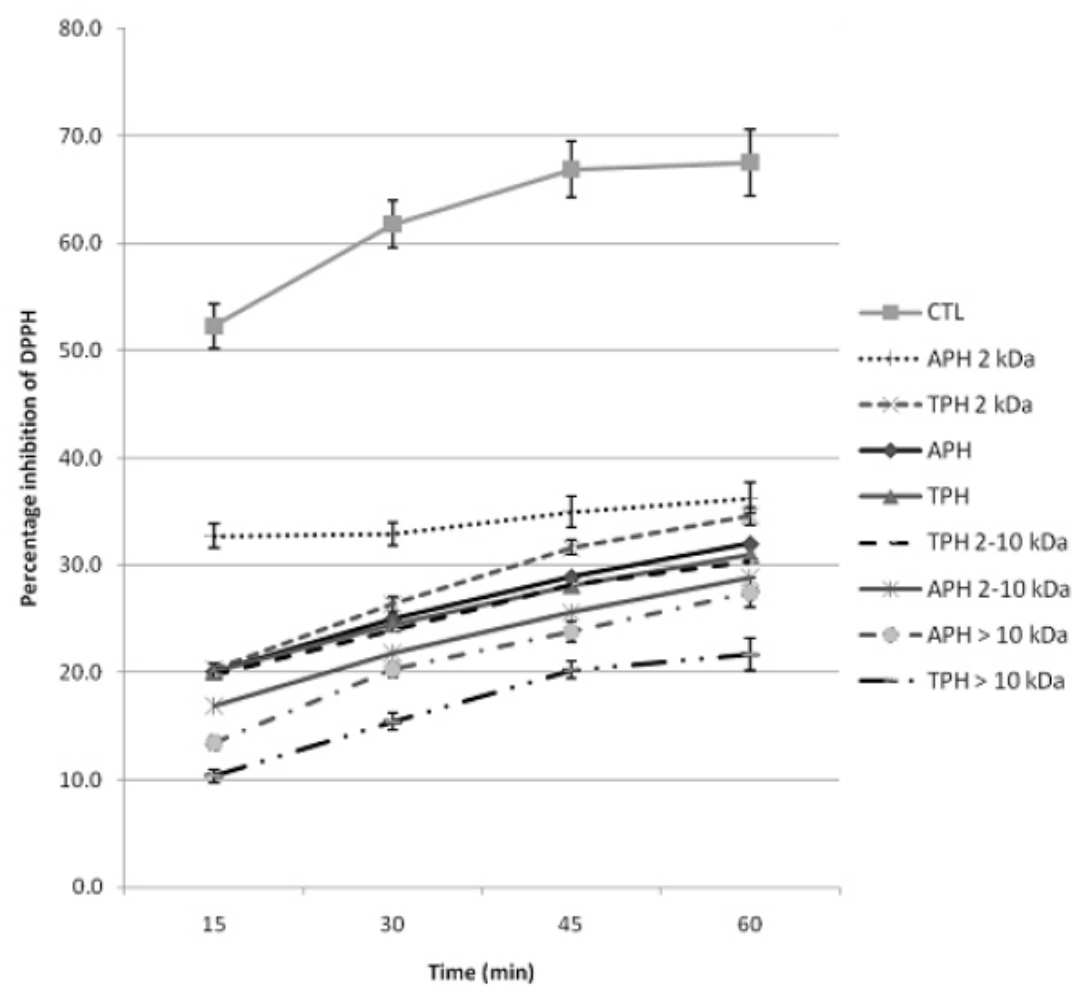

Figure 16: DPPH radical scavenging of APH, TPH and their ultra-filtered fractions, $<2 \mathrm{kDa}, 2-$

$10 \mathrm{kDa}$, and $>10 \mathrm{kDa}$. 


\begin{tabular}{|l|l|}
\hline Sample & ORAC $(\mu$ M Trolox/g of sample $)$ \\
\hline TPH & $434 \pm 16 \mathrm{a}$ \\
\hline TPH $<2 \mathrm{kDa}$ & $270 \pm 8 \mathrm{~b}$ \\
\hline TPH $>2 \mathrm{kDa}$ & $345 \pm 15 \mathrm{c}$ \\
\hline APH & $269 \pm 4 \mathrm{~b}$ \\
\hline APH $<2 \mathrm{kDa}$ & $149 \pm 7 \mathrm{~d}$ \\
\hline APH $>2 \mathrm{kDa}$ & $241 \pm 9 \mathrm{e}$ \\
\hline
\end{tabular}

Table 4: ORAC values of APH, TPH and their ultra-filtered fractions. Statistical differences were evaluated by a one-way ANOVA using SPSS 11.0 for windows 7 (SPSS Inc., Chicago). Difference were analyzed using Fisher LSD test, $\mathrm{P}<0.05$ was considered significantly different and data are means \pm standard error.

The amino acid tyrosine and tryptophan both contain aromatic ring that can form a stable radical intermediates after donation of a proton to break the radical chain reactions (Arcan and Yemenicioğlu 2007). Methionine, is an amino acid that can prevent radical reactions and its potency is believed to be superior to that cysteine, histidine and phenylalanine (Dávalos et al. 2004). The position of the amino acid and as well as the length of the peptides has a role in its antioxidant activity, this could be the reason differences in radical scavenging power of the different peptide fractions. Free amino acids present in $<2 \mathrm{kDa}$ fractions certainly contributed to its activity. Unfortunately, it was not possible to determine the percentage or identity free amino acids present in less than $2 \mathrm{kDa}$ fractions. 


\subsection{Ferrous ion-chelating activity}

The chelating properties of the APH, TPH and fractions were measured by monitoring the formation of the complex between ferrozine and $\mathrm{Fe}^{2+}$ ions at $500 \mathrm{~nm}$ (figure 17). When the

formation of the complex Ferrozine/ $\mathrm{Fe}^{2+}$ is disturbed, it means the compound has the chelating properties and this will result in the decrease of the red color and estimation of the metal chelating activity (Yamaguchi et al. 2000). TPH $2 \mathrm{kDa}$ had $16.8 \%$ chelating effect at $20 \mu \mathrm{g} / \mathrm{mL}$, TPH2-10kDa had 21.6\% chelating effect and TPH had 11.5\% chelating effect. At lower concentrations, ultra-filtered fractions 2 and $2-10 \mathrm{kDa}$ of TPH had higher chelating effect compared to the whole TPH but at higher concentrations $(43.8 \%$ at $200 \mu \mathrm{g} / \mathrm{L}) \mathrm{TPH}$ was more active than its fractions. APH $>10 \mathrm{kDa}$ was the most active at low concentration $(20 \mu \mathrm{g} / \mathrm{mL})$ $16.9 \%$, and APH activity was $31.8 \%$ at higher concentration $(200 \mu \mathrm{g} / \mathrm{mL})$. In summary, Trypsin hydrolysate had a better chelating properties compared to Alcalase at similar concentrations. This could be due the presence of amino acid like histidine, which is known to chelate metals or trap lipid radicals (Je et al. 2004; Rajapakse et al. 2005; Je et al. 2005). 


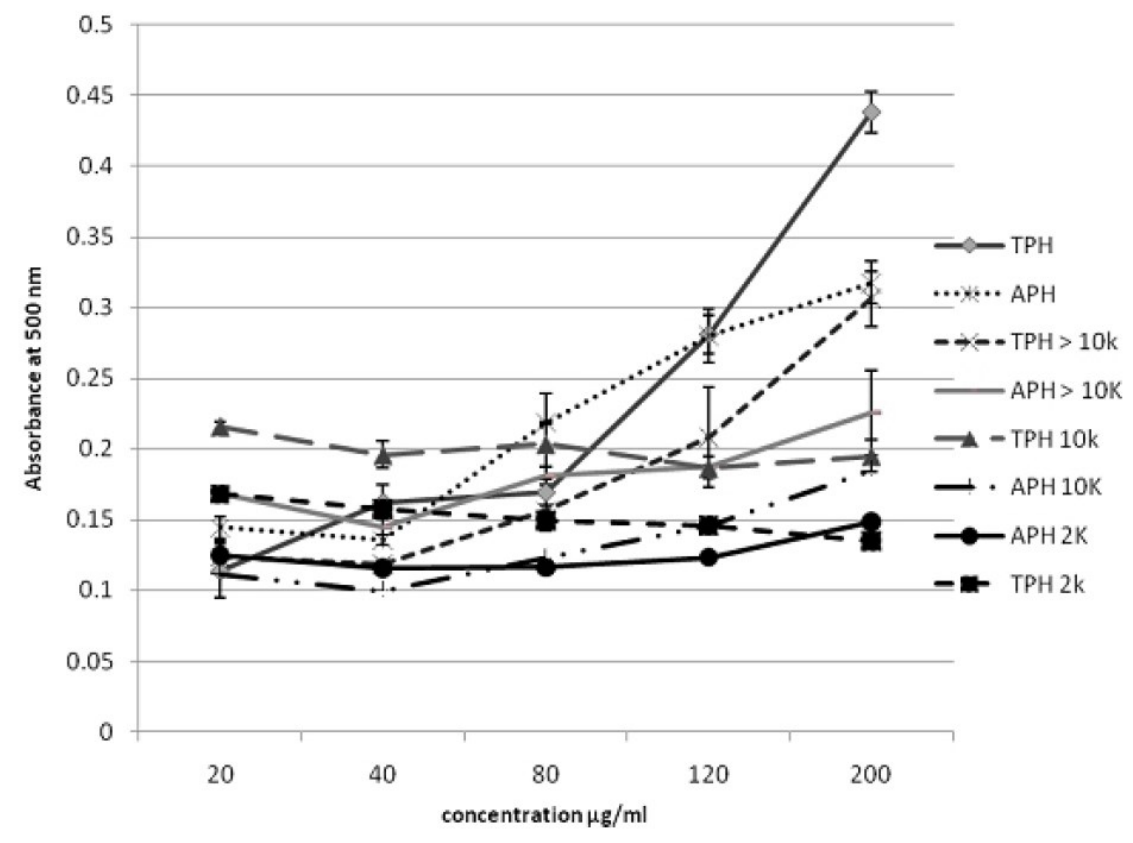

Figure 17: Ferrous ion-chelating activity of the, TPH, APH, and their ultra-filtered fractions.

TPH: trypsin digest; TPH 2kDa: trypsin digest $<2 \mathrm{kDa}$; TPH 2-10 kDa: trypsin digest 2 to $10 \mathrm{kDa}$; TPH: trypsin digest $>10 \mathrm{kDa}$. Each value is expressed as mean $\pm \mathrm{SD}(\mathrm{n}=3)$

\subsection{Linoleic acid autoxidation protection by oat protein hydrolysates}

The antioxidant activity of the TPH and APH were measured in the linoleic acid emulsion system, using $\alpha$-tocopherol as a reference (figure 18). The formation of lipid peroxides was inhibited by addition of APH and TPH at a final concentration of $0.4 \mathrm{mg} / \mathrm{mL}$ from day 1 to day 5. From these results it can be concluded that APH and TPH contain peptides that can inhibit formation of lipid hydroperoxides in food products. Purified peptides from enzymatic hydrolysis (Rival et al. 2001; Saiga et al. 2003), as well as protein hydrolysates from other foods (Zhu et al. 2006a; Li et al. 2008) has been shown to inhibit the autoxidation of linoleic acid. Increased antioxidant activity of protein hydrolysates and peptides can be due to increase in 
hydrophobicity, which increases their interaction with lipids (Saiga et al. 2003). The amino acid histidine, at the $\mathrm{N}$-terminus of the peptide has been shown to increase the antioxidant activity of peptides in the linoleic acid emulsion assay.

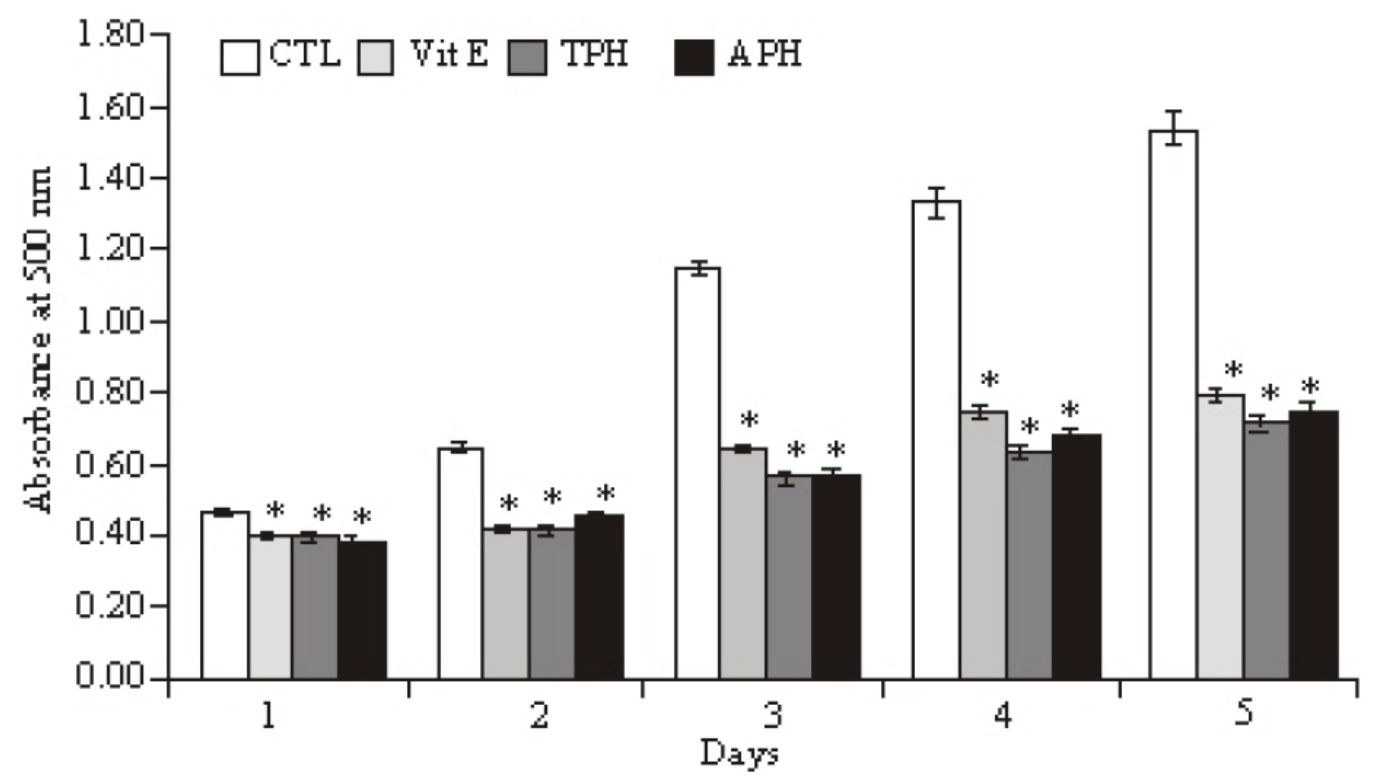

Figure 18: Reduction of lipid peroxides in a linoleic acid emulsion system of APH, TPH, Control and vitamin E ( $\alpha$-tocopherol), the effects of both APH and TPH were significantly different compared to control $(\mathrm{P}<0.01)$. 


\subsection{Conclusion}

In conclusion, APH $2 \mathrm{kDa}$ had higher DPPH radical scavenging compared to TPH $2 \mathrm{kDa}$. APH and TPH had similar DPPH radical scavenging. ORAC value for TPH was higher than APH. Ferrous ion chelating assay showed that ultra-filtered fractions had higher chelating activity at lower concentration, and TPH had higher chelating activity at $200 \mu \mathrm{g} / \mathrm{mL}$. Linoleic acid autoxidation of both APH and TPH was compared to vitamin E, the inhibition was similar to antioxidant vitamin $\mathrm{E}$, and the inhibition activity was higher in days 4, and 5 . 


\section{Chapter 4}

\section{Investigation of the effect of pre-treatment of oat brans with different carbohydrases on the extraction of protein, and on antioxidant capacity of hydrolyzed proteins}




\section{Introduction}

The extraction of proteins from foods and the use of proteases to hydrolyze them may prevent allergenicity and liberate biological active peptides. Common methods to extract proteins from cereals are often performed under salts or alkaline conditions (Cluskey et al. 1973; Ma 1985). However, in crops such as cereals extracting proteins from bran is difficult under alkaline conditions because they are linked to fibers and because of high viscosity of slurries that make proteins precipitation difficult. In addition, the formation of lysinoalanine can occur and thereby reduce the nutritional properties (Wang et al. 1999) .Pretreatment, utilizing carbohydrases, to extract proteins from plants at neutral and basic $\mathrm{pH}$ has been shown to increase protein yields (Ansharullah et al. 1997; Grossman et al. 1980). This is because enzymes disintegrate the cell wall matrix; hydrolyze the plant cell wall polysaccharide matrix. In a previous study, some carbohydrases were effectively shown to increase protein extraction yields from rice brans (Guan and Yao 2008). The use of carbohydrases in other cereals has not been investigated.

In this chapter, the effectiveness of extraction of proteins from medium oat bran using amyloglucosidase, amylase, viscozyme, and celluclast, and investigating the antioxidative activity of the protein isolate as well as alcalase hydrolysates are covered. The use of tandem mass spectrometry for identification of peptides is also presented. Figure 19 shows an illustration of the overall work done in this part of my research work. 


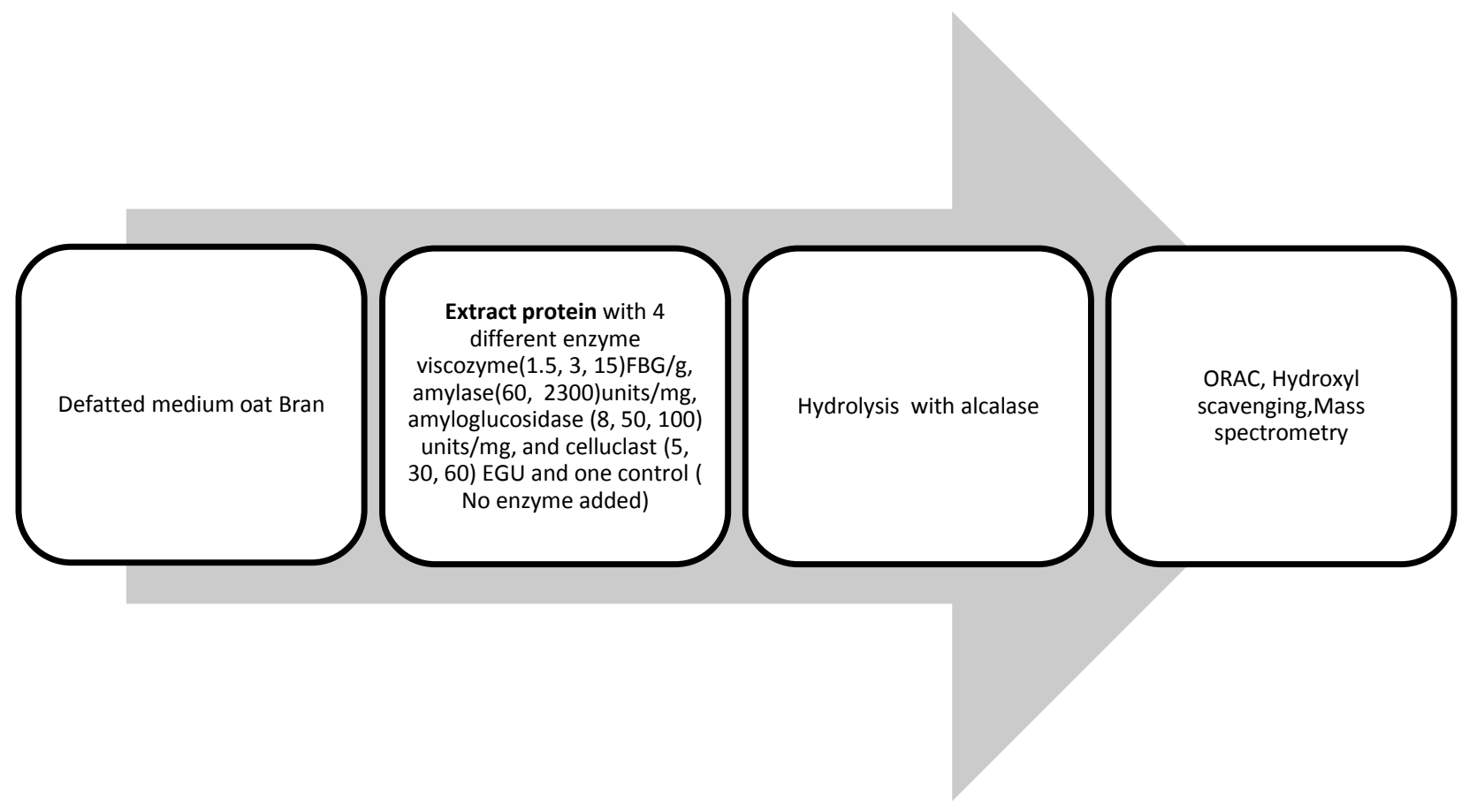

Figure 19: Schematic representation of experimental procedures of work done in chapter 4

\section{Results and discussion}

\subsection{Protein extraction in the presence of carbohydrases}

Alkaline protein extraction is associated with low protein yield, even though the protein extracted using this method has high nutritional content (Wang et al. 1999). This could be due to the presence of high amounts of fiber as well as presence of the membrane bound glycoproteins making the slurry viscous and in this case, proteins are less likely to precipitate at their isoelectric points. In order to compare the effectiveness of the protein extraction from medium oat bran enzymes amyloglucosidase, amylase, viscozyme, and celluclast were used. Three different concentration of each enzyme was investigated, except for amylase (only two). 
The results are summarized in table 5. The control sample had no enzyme added to it and it had $54 \%$ protein content. This value was similar to the content of proteins extracted using celluclast 5-60 EGU/g. The samples that were treated with amyloglucosidase 8 units/g had $82 \%$ protein content. Increasing the concentration of amyloglucosidase from50 to 100 units $/ \mathrm{g}$ decreased the protein content. This could be explained by the presence of higher amount of polysaccharides in the sample. Brans that were treated with alpha-Amylase 60 and 2300 units/g and viscozyme at concentrations of 3 and $15 \mathrm{FBG} / \mathrm{g}$ had similar protein content, about 70\%. In a previous study, different concentrations of viscozyme under different conditions was used to pretreat oat bran before protein extraction, the best environment was found to be $\mathrm{pH} 4.6$, incubation time of 2.8 $\mathrm{hr}$, temperature $44^{\circ} \mathrm{C}$, and viscozyme $3 \mathrm{FBG} / \mathrm{g}$. Under these conditions, the protein content of the supernatant was 56\% (Guan and Yao 2008). In this thesis, it was found thatpretreating the bran with viscozyme $3 \mathrm{FBG} / \mathrm{g}$ increased the yield to $68 \%$. This difference could be due to that the protein content in our study was evaluated in protein isolates (after centrifugation at 10,000 $\mathrm{g}$ of the supernatant) rather than in the supernatant (Guan and Yao 2008). The protein content of isolate is always higher than protein content of the concentrate (supernatant). The precipitation at isoelectric points removes the interfering non-protein molecules. One study reported that a combination of phytase and xylanase for extraction of proteins from rice bran at $\mathrm{pH} 5.0$, yielded $92.0 \%$ of proteins (Wang et al. 1999). The concentrations of the enzymes, $\alpha$-amylase, celluclast, and viscozyme used for work performed as part of this thesis were based of those used for extraction of proteins from heat stabilized defatted rice bran (Tang et al. 2003). 


\begin{tabular}{lcllc}
\hline Enzyme & pH & $\begin{array}{l}\text { Concentration (unit/ } \\
\text { g defatted bran) }\end{array}$ & $\begin{array}{l}\text { protein content } \\
(\%) \text { of isolates }\end{array}$ & $\begin{array}{l}\text { ORAC }(\mu \mathrm{M} \\
\text { TE/g isolate })\end{array}$ \\
\hline No enzyme & 6.5 & 0 & 54 & $53 \pm 12^{\mathrm{a}}$ \\
Amylase, units & 6.5 & 60 & 70 & $117 \pm 13^{\mathrm{c}}$ \\
& & 2300 & 72 & $165 \pm 16^{\mathrm{e}}$ \\
Celluclast, EGU & 5.5 & 5 & 53 & $73 \pm 13^{\mathrm{a}}$ \\
& & 30 & 53 & $95 \pm 12^{\mathrm{b}, \mathrm{c}}$ \\
Viscozyme, FBG & 4.5 & 60 & 52 & $89 \pm 6^{\mathrm{b}}$ \\
& & 3 & 42 & $65 \pm 12^{\mathrm{a}}$ \\
Amyloglucosidase, & 5.5 & 8 & 68 & $106 \pm 8^{\mathrm{c}}$ \\
\multicolumn{1}{c}{ units } & & & 70 & $111 \pm 12^{\mathrm{c}, \mathrm{d}}$ \\
& & 50 & 82 & $125 \pm 3^{\mathrm{d}}$ \\
& 100 & 57 & $86 \pm 4^{\mathrm{b}}$ \\
& & 47 & $79 \pm 8^{\mathrm{b}}$ \\
\hline
\end{tabular}

Table 5: Effect of different concentrations of Amylase, celluclast, viscozyme, and amyloglucosidase on protein content; antioxidant activity (ORAC value $\mu \mathrm{M} \mathrm{TE} / \mathrm{g}$ sample) of protein isolates. Statistical differences were evaluated by a one-way ANOVA using SPSS 11.0 for windows 7 (SPSS Inc., Chicago). $\mathrm{P}<0.05$ was considered significantly different between the groups using the Fisher LSD test (mean \pm standard error).

\subsection{Antioxidant activities of hydrolysates from bran treated with carbohydrases}

\subsubsection{Oxygen radical absorbance capacity (ORAC) assay}

ORAC values of protein isolates and alcalase digested proteins are displayed in Table 5. The ORAC value for the sample that was not treated with an enzyme was $53 \pm 12 \mu \mathrm{M} \mathrm{TE} / \mathrm{g}$. Brans treated with viscozyme had ORAC values between $65-111 \mu \mathrm{M} \mathrm{TE} / \mathrm{g}$, and this increase was associated with increase of protein contents. For amyloglucosidase treated brans, increasing the concentrations from 8 units to 100 units/g of defatted bran resulted in decreasing ORAC value 
from $125 \pm 3$ to $79 \pm 8 \mu \mathrm{M} \mathrm{TE} / \mathrm{g}$. This can be explained by the fact that increasing the concentration of this enzyme resulted in greater degradation of polysaccharides and that may have co-precipitated with proteins. Figure 20 shows the peroxyl radical scavenging of different protein samples hydrolyzed with alcalase. The highest activity belonged to viscozyme and celluclast. $\alpha$-amylase 2300 units/g had the lowest activity $(150 \pm 27 \mu \mathrm{M} \mathrm{TE} / \mathrm{g})$, and the control had the activity of $243 \pm 31 \mu \mathrm{M} \mathrm{TE} / \mathrm{g}$. The peroxyl radical scavenging activity of proteins hydrolyzed with alcalase was higher than the non-digested ones. This is because hydrolysisreleased specific peptides or amino acids with strong antioxidant properties. In fact, the sequence of peptide identified here contains amino acids like tyrosine, histidine and phenylalanine which are good electron donors.

It is also possible that Tryptophan or cysteine are present in the hydrolysates, since they are powerful peroxyl radical scavenger, and they contributed to the ORAC values. Methionine contains sulfur that can be oxidized and therefore prevent or reduce oxidative damage to foods and components (Ngo et al. 2010). The length of the peptide as well as the position of the amino acids contributes to the antioxidant activity (Davalos et al. 2004; Sheih et al. 2009). The difference in antioxidant activity observed in the protein hydrolysates is due to some of these factors. 


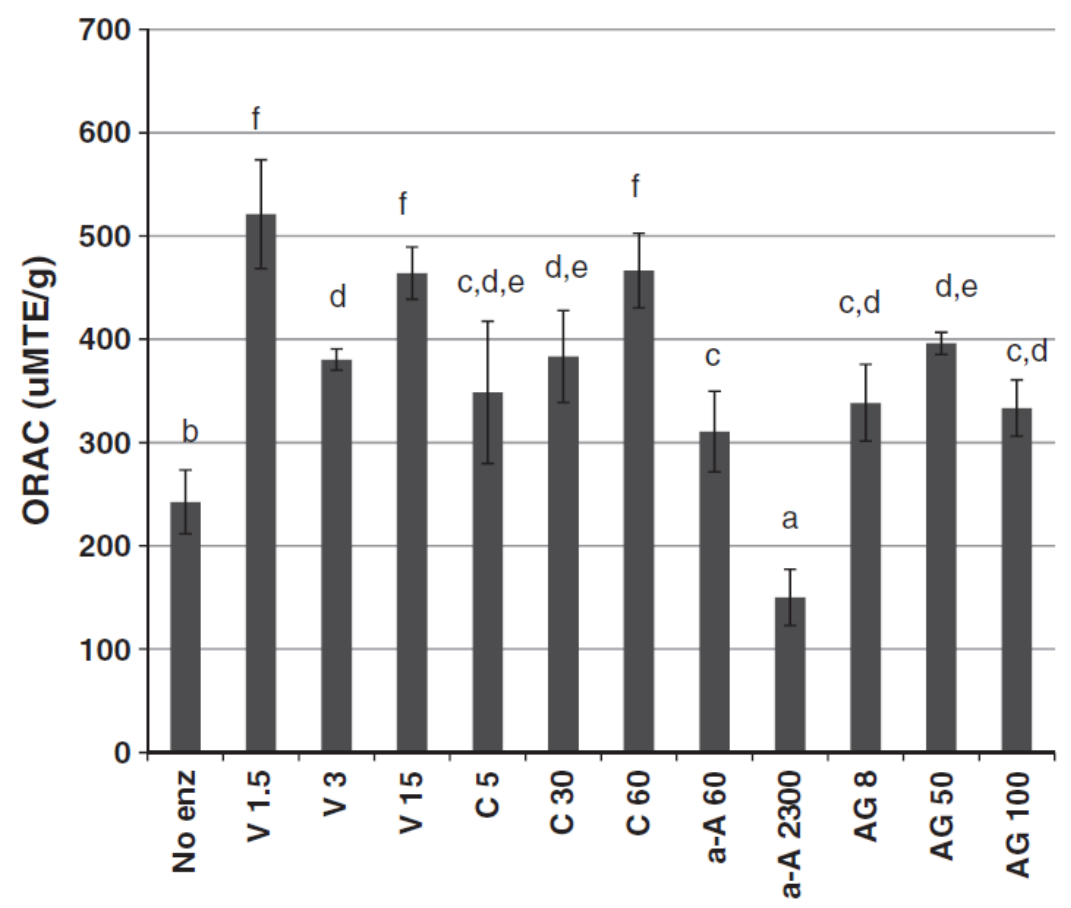

Figure 20: ORAC value for protein isolates extracted in brans pretreated with different concentrations of carbohydrases followed by hydrolysis with alcalase. V: viscozyme, C: celluclast, a-A: alpha-amylase, $A G$ : amyloglucosidase. Values are mean $\pm \mathrm{SD}(\mathrm{n}=3)$. Different letters indicate significant difference between groups $(\mathrm{P}<0.05)$.

\subsubsection{Hydroxyl radical scavenging activity}

Hydrogen peroxide and superoxide can react and form hydroxyl radical (HO•) which is a highly reactive species. In the presence of metal ions such as iron and copper, $\mathrm{HO} \bullet$ reacts with DNA, proteins, lipids and polypeptides (Lee et al. 2004). The formation of hydroxycyclo-hexadienyl radicals can occur by reaction of aromatic compounds with $\mathrm{HO} \bullet$, this intermediate can further react with oxygen to give peroxyl radicals or decomposing to phenoxyl-type radicals by water elimination (Lee et al. 2004). The HO• scavenging activity of the, control as well as the samples 
treated with different enzyme is shown in figure 21 , and are expressed as $\%$ inhibition. The lowest percentage inhibition belonged to hydrolysates from brans treated with celluclast. Brans treated with $5 \mathrm{EGU} / \mathrm{g}$ of celluclast had the \% inhibition of, this value is lower than of the control which is $17.5 \pm 0.8$. The samples that were treated with amyloglucosidase and viscozyme, all three concentrations had higher percentage inhibition compared to the control. Comparing these results with ORAC, which measures the peroxyl radical scavenging activity; there were differences in activities of the samples. This may be because the $\mathrm{HO} \bullet$ radical scavenging activity is dependent on the reducing power while the peroxyl radical assay is dependent on electron or proton donating groups (Rice-Evans et al. 1995).

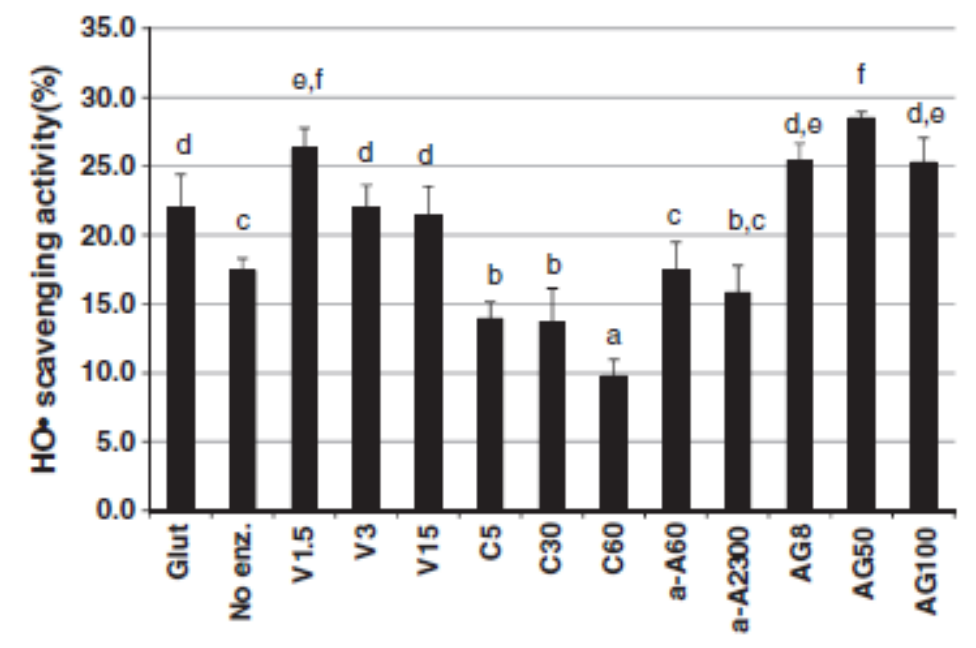

Figure 21: HO scavenging activity of protein hydrolysates from control bran treated with different concentration of carbohydrases. Statistical differences were evaluated by a one-way ANOVA (Fisher LSD test) using SPSS 11.0 for windows 7 (SPSS Inc., Chicago). P $<0.05$ was considered significantly different between the groups (mean \pm standard error). 
Asn-Gly-Leu-Glu-Gly-Leu-Lys is a hepta-peptide from giant squid muscle that has shown to possess antioxidant activity (Rajapakse et al. 2005). Hydrophobic peptides from soybean were shown to possess antioxidant activity (Chen et al. 1995). Several hydrophobic amino acids have been found in oat proteins, these amino acids are Leu, Val, and Ala, and they are known to contribute to radical scavenging properties. These amino acids can facilitate the interaction of peptides with linoleic acid and protect it from oxidation (Rajapakse et al. 2005). The amino acids in the alcalase peptide and the proper sequencing of these amino acids can be the reason for the antioxidant activity of this peptide (Chen et al. 1995; Suetsuna et al. 2000).

\subsection{Peptide identification}

The QSTAR ${ }^{\circledR}$ QqTOF hybrid mass spectrometer, is the instrument used in this research to analyze the alcalase hydrolysates, from viscozyme and control. This machine can identify biological and functional peptides. The oat bran Alcalase hydrolysates' tandem mass spectrometry was conducted on multiply charged ions over $80 \mathrm{~min}$. An example of ion count chromatogram is shown in figure 22 .

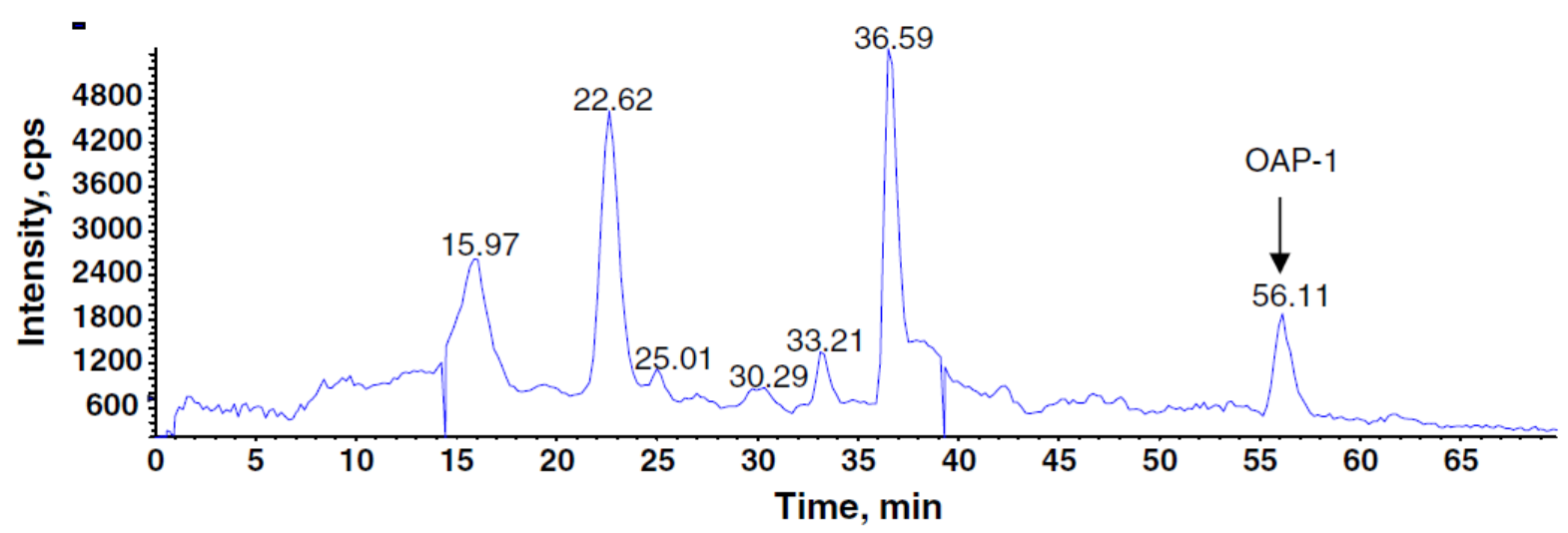

Figure 22: Ion count chromatogram of oat bran Alcalase hydrolysates. The peak for the peptide OAP-1 is shown at retention time $56.11 \mathrm{~min}$ 
Figure 23A shows the average mass spectrum of peptide eluted between 55.5 and $55.7 \mathrm{~min}$. The mass spectrometer was set automatically to perform MS/MS analysis of multiple charged $\left(2^{+}\right.$and $3^{+}$) only. This is because there is greater probably that multiple charged peaks would belong to peptides. Figure 23B shows an example of a group of peaks that belong to a double charged peptide. This is evidenced by the difference of $0.5 \mathrm{Da}$ between two consecutive isotopic peaks visible at $\mathrm{m} / \mathrm{z} 630.34,630.85$, and 631.34 . This peak was then automatically selected for MS/MS analysis. b- and y-ions are most common fragments observed on MS/MS spectra, b-ions are those that extend from amino terminus while y-ions are those that extend from carboxy terminus.

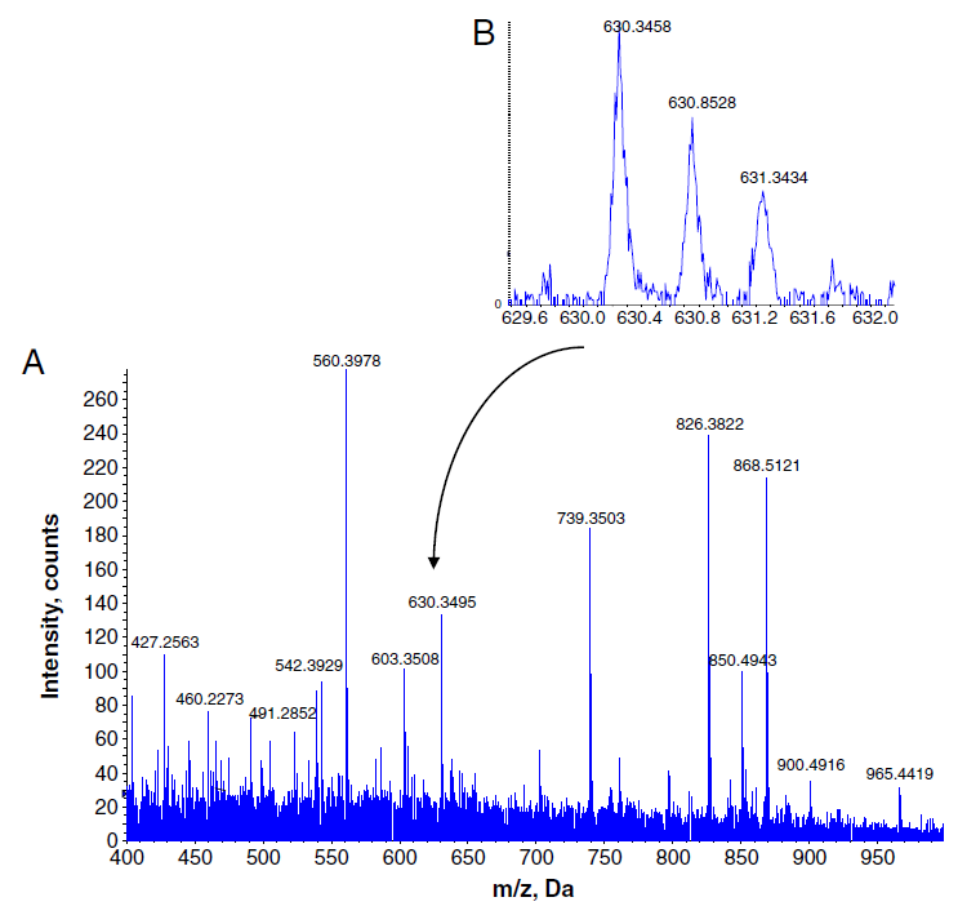

Figure 23: Time of flight MS scan of alcalase digested control oat bran protein at retention time $55.6 \mathrm{~min}$. A: Mass spectrum of peptides eluted between 55.5 and $55.7 \mathrm{~min}$. B: Expansion showing a double charged peak (OAP-1) that automatically submitted for MS/MS analysis. 
Figure 24, shows the MS/MS spectrum of OAP-1. b-ions were the most important for its identification. The peak at $\mathrm{m} / \mathrm{z} 1015.50$ (b9) resulted from $[\mathrm{M}-1 \mathrm{le}-\mathrm{Leu}]^{+}$. Other fragments are b8

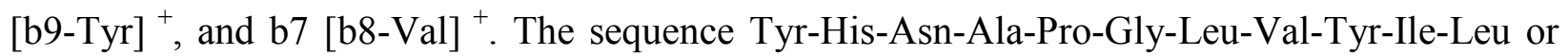
YHNAPGLVYIL was identified and named OAP-1. It is derived from 12S globulin peptide fragment 74-84. MS/MS data from other multiple charged peaks at m/z 692.36 (OAP-2) 582.34 (OAP-3) and 762.43 (OAP-4) were elucidated in the same manner. Their sequences are DVNNNANQLEPR or Asp-Val-Asn-Asn-Asn-Ala-Asn-Gln-Leu-Glu-Pro-Arg (OAP-2) derived from 12S globulin fragment 160-171; GQTVFNDRLRQGQLL or Gly-Gln-Thr-Val-Phe-AsnAsp- Arg-Leu-Arg-Gln-Gly-Gln-Leu-Leu (OAP-3) from 12S globulin peptide fragment 376-392 and VVNNNGQTVFNDRLRQGQLL or Val-Val-Asn-Asn-Asn-Gly-Gln-Thr-Val-Phe-AsnAsp-Arg-Leu-Arg-Gln-Gly-Gln-Leu-Leu (OAP-4) from 12S globulin peptide fragment 371-390. All of these peptides were present in the control sample; however, the peptide OAP-2 was only present in the samples that were treated with $15 \mathrm{FBU} / \mathrm{g}$ viscozyme. MS/MS analysis of multiple charge peaks has been used to identify peptides in protein hydrolysates (Drogaris et al. 2009; Yang et al. 2007) and biological fluids (Cirulli et al. 2008). Globulin was one of the major proteins in the bran concentrate as analyzed by polyacrylamide gel electrophoresis (Guan et al. 2007). It is also possible that in the protein isolate prepared during this study, globulin was the major protein as all four peptides identified are its fragments. However, it is also possible that 12S globulin derived peptides easily formed multiple charged ions compared to peptides from other oat bran proteins. More separation of the hydrolysates will allow us to identify more peptides from different proteins. From the literature, peptides derived from 11S globulin, 12S 
globulin and avenin-3 are potential antihypertensive peptides (Cheung et al. 2009; Gu et al. 2011).

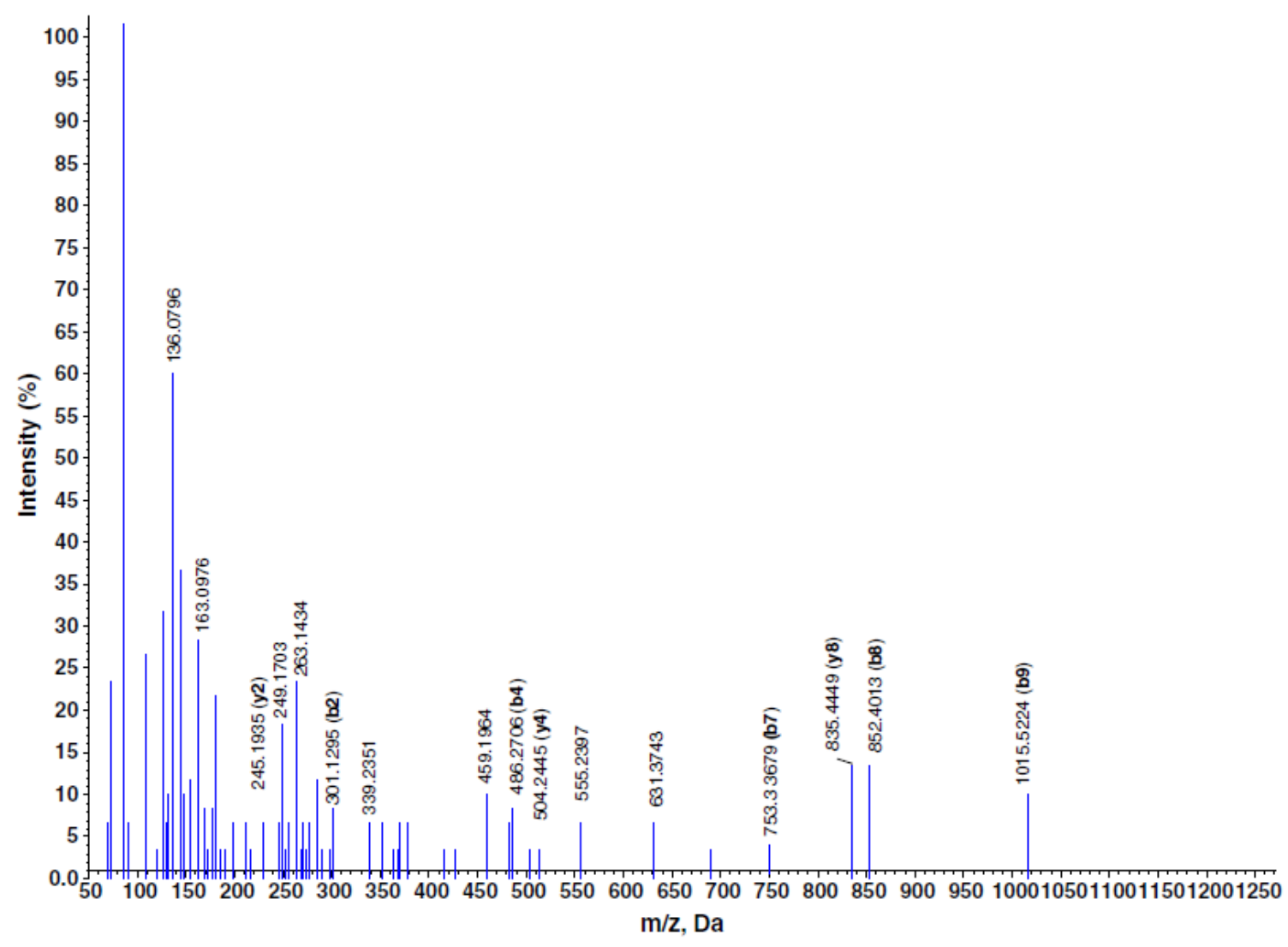

Figure 24: Time of flight (MS/MS) of peptide OAP-1 (m/z 630.34) identified in control, oat bran alcalase protein hydrolysates.

\subsection{Possible contribution of identified peptides to antioxidant activities}

OAP-1 peptide (Tyr-His-Asn-Ala-Pro-Gly-Leu-Val-Tyr-Ile-Leu) contains tyrosine which is known to be important for metal chelating and hydroxyl radical activities but can also lower superoxide radical scavenging property (Gülçin 2007). It also contains histidine, which is known to increase the metal chelating activity and scavenge radicals because its imidazole group can transfer a hydrogen atom and donate a single electron (Grune et al. 2013). All four peptides 
contain asparagine that can increase DPPH radical activities and leucine that may be important in superoxide anion radical scavenging activities (Chen et al. 1996). At the same time OAP-1, and OAP-2 (Asp-Val-Asn-Asn-Asn-Ala-Asn-Gln-Leu-Glu-Pro-Arg) contain proline (Pro) that lowers superoxide anion activity (Udenigwe and Aluko 2011). OAP-2, 3 (Gly-Gln-Thr-Val-PheAsn-Asp-Arg-Leu-Arg-Gln-Gly-Gln-Leu-Leu) and 4 (Val-Val-Asn-Asn-Asn-Gly-Gln-Thr-ValPhe-Asn-Asp-Arg-Leu-Arg-Gln-Gly-Gln-Leu-Leu) contain aspartic acid (Asp) that has electron donating and metal chelating abilities of hydrolysates (Aluko 2012). Phenylalanine (Phe) residues present in OAP-3 and 4 may have contributed to the antioxidant activities of different oat bran protein hydrolysates (Aluko 2012; Grune et al. 2013). It is not possible to determine or predict the contribution of identified peptides to the activities of oat bran protein hydrolysates. This is because quantification was not possible. 


\section{Chapter 5}

\section{Investigation of the potential of trypsin digested oat bran proteins to reduce oxidative stress in a mice model receiving high fat diet}




\section{Introduction}

Obesity or excessive body weight known to be result from the intake of high fat or high calorie diet, has been associated with many chronic diseases such as inflammation, increased blood pressure, glucose intolerance, heart disease, diabetes and dyslipidemia (Takahashi et al. 1999). High amounts of ROS have been demonstrated in obesity (Furukawa et al. 2004). The damage from ROS has been related to obesity and some of its complications (West 2000). At normal level, some ROS are involved in signaling pathway through reversible oxidation of proteins such as seen in protein kinases or transcription factors (Poli et al. 2004). However, at higher levels ROS cause irreversible oxidation of proteins, DNA and lipids (Valko et al. 2007). In order to fight the ROS, cells contains enzymatic antioxidants. Enzymes, such as SOD, CAT, GPx and non-enzymatic antioxidants such as GSH, vitamin E, vitamin C (Halliwell 1989). The activity of these enzymes has been shown to be low in the plasma of obese human as well as animals (Furukawa et al. 2004). Some studies have reported that the addition of phytochemicals to high fat diets reduced oxidative stress and ROS (Feillet-Coudray et al. 2009). The use of proteins from plants as well as their hydrolytic products such as peptides have biological activities that can be beneficial in the treatment or prevention of some chronic diseases caused by oxidative stress (Wang and De Mejia 2005). Protein hydrolysates derived from pea has been shown for example to reduce blood pressure in humans and hypertensive rats ( $\mathrm{Li}$ et al. 2011b). It has been demonstrated that, the oat phenolic lowered the risk of the cardiovascular disease through reduction of both plasma cholesterol and oxidation of low-density lipoprotein in humans and animals (Chen et al. 2004). Digested oat proteins have antioxidant properties in vitro (Jodayree et al. 2012), however their effects in vivo have not been investigated. As part of this thesis, hydrolyzed proteins were used for animal experiments because of their better scavenging 
activities determined in Chapter 3. This chapter then covers supplementation of high fat diet with oat protein hydrolysates and the effect on oxidative stress markers in CD1-mice. Specifically the following markers were determined

- Body weight, glucose level, respiratory exchange ratio

- Total antioxidant capacity of blood and tissues

- Antioxidant enzymes activities of blood and tissues

- Protein oxidation

- Oxidants like nitrates/nitriles, hydrogen peroxide

- Vitamins.

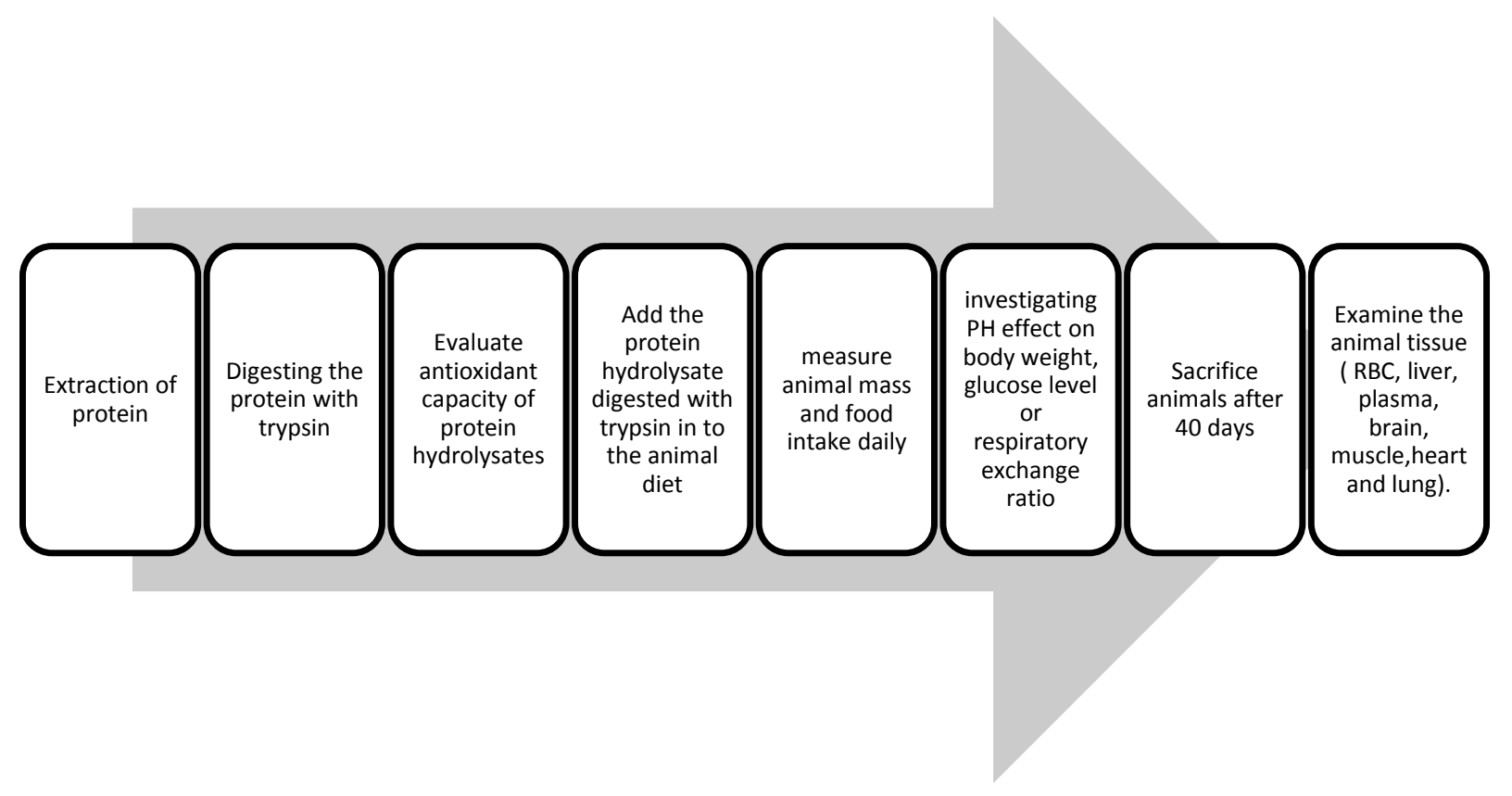

Figure 25: Illustration of work done in this chapter. 


\section{Results and discussion}

\subsection{Composition of digested oat proteins}

The amino acid (AA) composition of the oat protein hydrolysates (OPH) digested by trypsin was determined to contain aspartic acid/asparagine (8.3\%), glutamine/glutamic acid (21.1\%), serine (7.3\%), glycine $(9.0 \%)$, histidine $(2.1 \%)$, arginine $(7.6 \%)$, threonine $(4.2 \%)$, alanine $(6.2 \%)$, proline $(5.3 \%)$, tyrosine $(3.3 \%)$, valine $(4.9 \%)$, methionine $(0.9 \%)$, cysteine $(0.4 \%)$, isoleucine (4.0\%), leucine $(6.9 \%)$, phenylalanine $(5.0 \%)$, and lysine $(3.4 \%)$. This was determined by acid hydrolysis and pre-column derivatization with phenylisothiocyanate on reversed phase HPLC.

\subsection{Effect of OPH on red blood cells}

Oxygen radical absorbance capacity ORAC, total sulfhydryl (-SH) groups and peroxide levels were used to determine the oxidative status of erythrocytes or red blood cells (RBC). As mentioned in other sections ORAC is accepted as a standard procedure to measure the total antioxidant capacity of foods, dietary supplements, or biological samples (Prior et al. 2007; Ninfali et al. 2009). It measures the oxidative degradation of the fluorescent molecule (fluorescein), after it has been mixed with 2,2'-azobis(2-amidino-propane) dihydrochloride $(\mathrm{AAPH})$ a free radical generator. The free radical damages the fluorescence molecule, resulting in the loss of fluorescence. Antioxidants will protect the fluorescence molecule from free radicals or from oxidative degradation. The decomposition of fluorescein is measured and used to calculate the total antioxidant capacity or ORAC value. Due to high content of lipids, the presence of transition metals such iron and copper, and the oxygen supply, RBCs are vulnerable to oxidation (Delmas-Beauvieux et al. 1995). Oxidative damage of RBCs membrane mostly 
involves lipid peroxidation, and changes its fluidity. This which could be the reason of membrane, membrane-bound enzyme and receptor malfunctioning and this has been proposed as a general mechanism leading to Red blood cells (RBC) hemolysis involved and cell injury. In this thesis red blood cells of mice in group 4 (high fat diet $+100 \mathrm{OPH} \mathrm{mg} /$ food) had the highest ORAC value $(123.27 \pm 11.09 \mathrm{mM} \mathrm{TE} / \mathrm{mL})$ meaning that the addition of $100 \mathrm{mg}$ protein hydrolysates /g high fat food increased their scavenging capacity. The value was $26 \%$ higher compared to the activity $(96.47 \pm 6.62 \mathrm{mM} \mathrm{TE} / \mathrm{mL})$ of mice in high fat diet (figure 26). This suggests a possible interaction of the protein hydrolysates within cell membranes, which generally serve as a target for lipid peroxidation (Ferrali et al. 1997). There was no difference between the ND $(91.0 \pm 6.7 \mathrm{mM} \mathrm{TE} / \mathrm{mL})$ and $\mathrm{HF}$ diet $(96.5 \pm 6.6 \mathrm{mM} \mathrm{TE} / \mathrm{mL})$. Mice in group 3 $(\mathrm{HF}+10 \mathrm{mg} \mathrm{OPH} / \mathrm{g})$ had slightly lower ORAC value relative to ND and HF groups but this was not significantly different. The higher value in group $4(\mathrm{HF}+100 \mathrm{mg} \mathrm{OPH} / \mathrm{g})$ could be due to higher concentration of thiol moieties present in $\mathrm{RBC}$ as discussed below, or possibly OPH increased the synthesis of thiol containing proteins. Cysteine and methionine are sulfur containing amino acids found in $\mathrm{OPH}$ and their combined percentage in $\mathrm{OPH}$ is $1.3 \%$. There was no correlation between the peroxyl radical scavenging activity and the OPH concentration. 


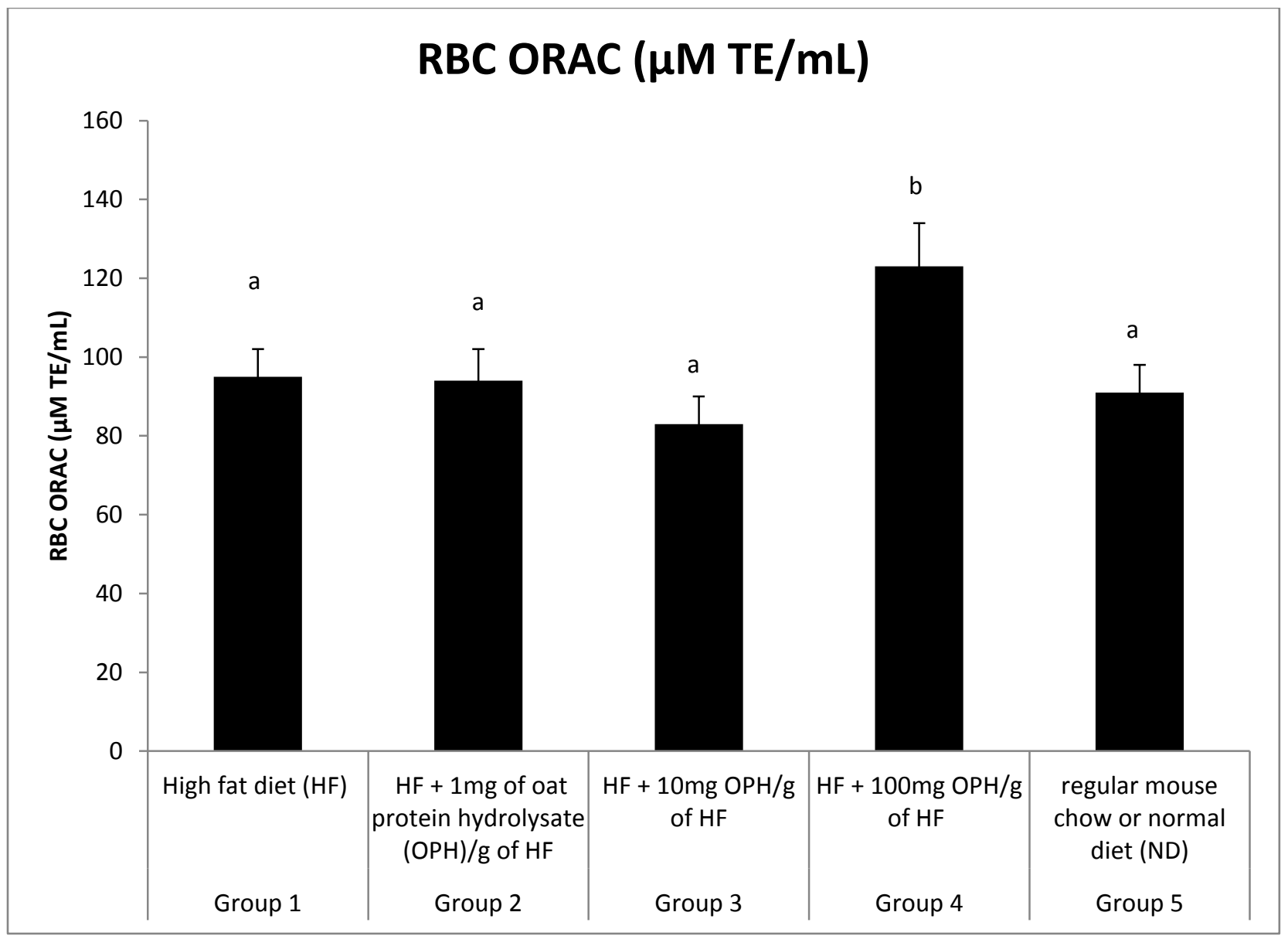

Figure 26: Radical scavenging activity (ORAC) of red blood cells of CD-1 mice. Statistical differences were evaluated by one-way ANOVA using SPSS 11.0 for windows 7 (SPSS Inc., Chicago). Values with $\mathrm{P}<0.05$ were considered significantly different between the groups using the LSD test (mean \pm standard error).

Ellman assay was used to determine the total thiol. Total thiol includes free amino thiols such as glutathione (GSH), cysteine, homocysteine and protein bound thiol (Malgorzata et al. 2004). Free thiol concentrations will provide an indication on the reduction capacity of the fluid or biological sample. GSH concentration in liver for example has been associated its detoxification potential. Thiol groups (-SH) play an important role in antioxidant reactions and regulation of 
electron transport, preserving the correct structure of the proteins (Rokutan et al. 1994). Measurement of the total sulfhydryl groups showed that ND, HF and group 3 (HF $+10 \mathrm{mg}$ $\mathrm{OPH} / \mathrm{g}$ ) had similar total thiol concentration. The total thiol concentration of group 4 (HF +100 $\mathrm{mg} \mathrm{OPH} / \mathrm{g}$ ) was significantly higher than group 1 (Figure 27). There was a correlation between the total thiol and the three concentration of $\mathrm{OPH}$ added to the diet $\left(\mathrm{R}^{2}=0.99\right)$.

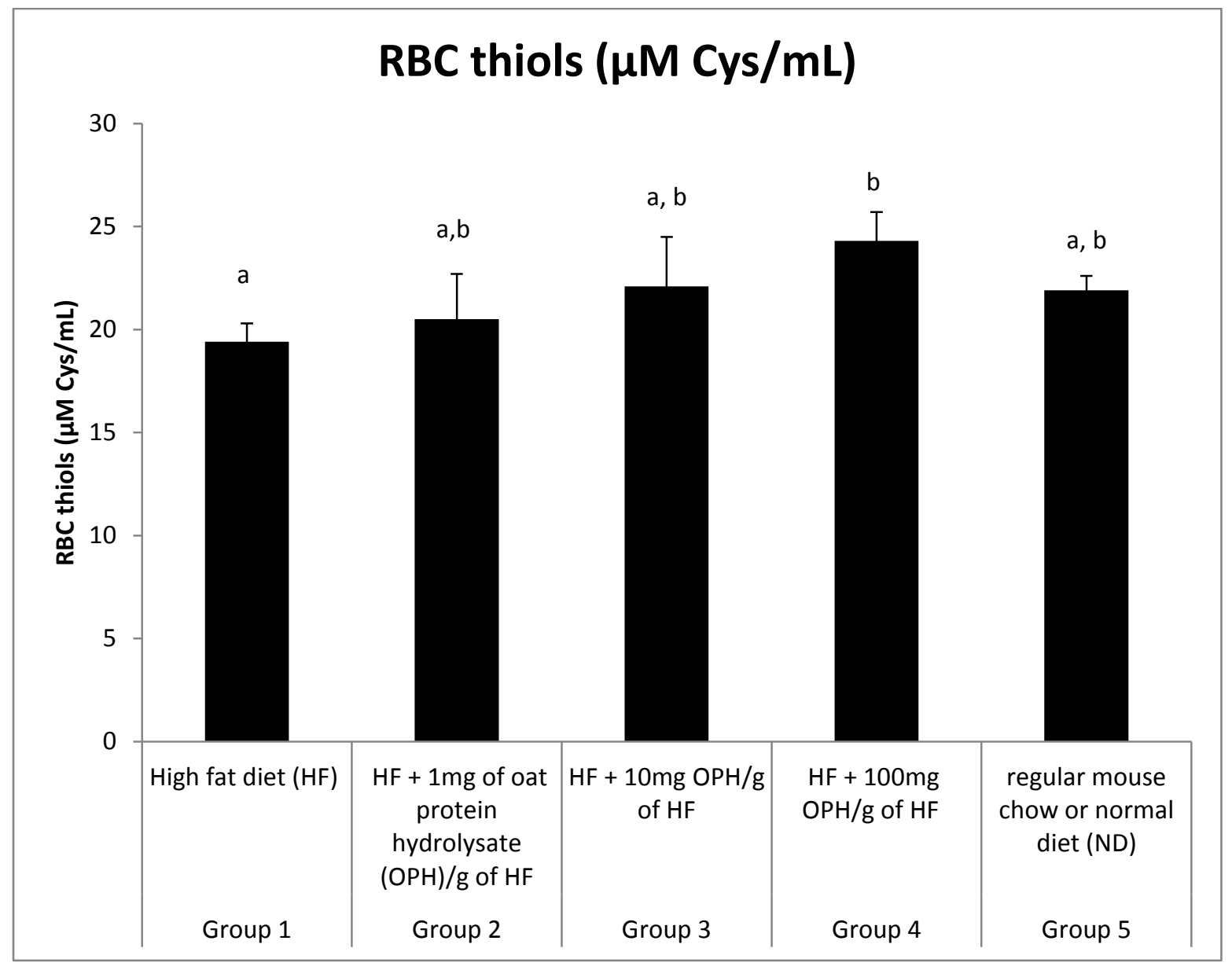

Figure 27: Total sulfhydryl groups in RBC of CD-1 mice. Statistical differences were evaluated by one-way ANOVA using SPSS 11.0 for windows 7 (SPSS Inc., Chicago). Values with $\mathrm{P}<0.05$ were considered significantly different between the groups using the LSD test (mean \pm standard error). 
Ferrous ion oxidation xylenol orange (FOX) assay was used to determine the peroxyl level (total peroxides ( $\left.\mathrm{LOOH}+\mathrm{H}_{2} \mathrm{O}_{2}+\mathrm{ROOH}\right)$ ). FOX assay estimates $\mathrm{H}_{2} \mathrm{O}_{2}$ concentration (Wolff 1994) . FOX method is based upon oxidation of reagent $\mathrm{Fe}^{2+}$ to $\mathrm{Fe}^{3+}$ by sample oxidizing agents, $\mathrm{Fe}^{3+}$ binds with reagent xylenol orange $(\mathrm{XO})$ to give a color complex having absorption maximum at $560 \mathrm{~nm}$ (Banerjee et al. 2003; Banerjee et al. 2002). Data from the FOX assay on plasma showed that HF groups had higher peroxide level compared to the ND. Addition of $1 \mathrm{mg} \mathrm{OPH} / \mathrm{g}$ diet slightly decreased $(\mathrm{p}>0.05)$ the peroxide level, while addition of $100 \mathrm{mg} \mathrm{OPH} / \mathrm{g}$ increased its amount $(\mathrm{p}<0.05)$ relative to HF diet only (Figure 28$)$.

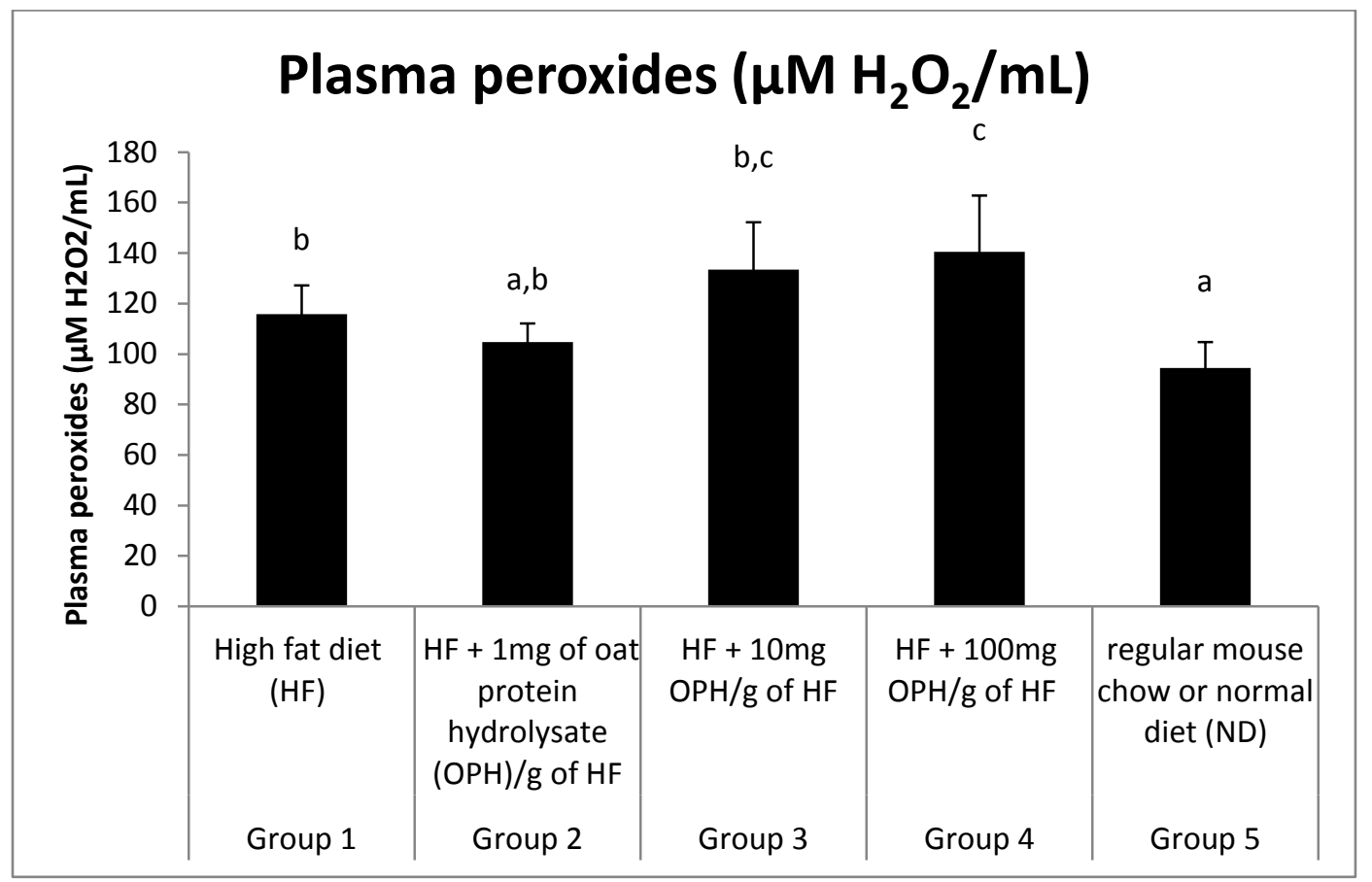

Figure 28: Levels of peroxides determined by FOX assay in the plasma of CD-1 mice. Statistical differences were evaluated by one-way ANOVA using SPSS 11.0 for windows 7 (SPSS Inc., Chicago). Values with $\mathrm{P}<0.05$ were considered significantly different between the groups using the LSD test (mean \pm standard error). 
The ORAC level in the plasma was investigated and it was found that there was no difference between different groups (Table 6). Difference in scavenging power of RBC and plasma could be due to presence of different proteins and small molecules in plasma. Peptides that contain thiol have been shown to have radical scavenging properties, and in this study thiol levels was increased in the RBC samples. In a study where rats were on HF diets supplemented with polyphenols, an increase of oxidation products was found in plasma proteins but not in lipid or antioxidant enzymes (Feillet-Coudraya et al. 2009) . Increase levels of lipid hydroperoxides $(\mathrm{LOOH})$, has been seen in the adipose tissue of obese mice, but not in the skeletal muscle and aorta (Furukawa et al. 2004). 


\begin{tabular}{|l|l|l|l|l|l|}
\hline & HF & HF+1mg & HF+10mg & HF+100mg & ND \\
\hline Final weight $(\mathrm{g})$ & $44.3 \pm 1.7^{\mathrm{a}}$ & $45.1 \pm 1.5^{\mathrm{a}}$ & $46.8 \pm 1.8^{\mathrm{a}}$ & $46.3 \pm 1.0^{\mathrm{a}}$ & $40.2 \pm 1.0^{\mathrm{b}}$ \\
\hline Food intake $(\mathrm{kCal} /$ day) & $24.1 \pm 0.7^{a}$ & $25.5 \pm 1.4^{a}$ & $25.4 \pm 0.7^{a}$ & $26.7 \pm 1.2^{a}$ & $20.8 \pm 0.7^{\mathrm{b}}$ \\
\hline Locomotor activity (Counts) & $1227 \pm 184^{\mathrm{a}}$ & $1112 \pm 173^{\mathrm{a}}$ & $964 \pm 144^{\mathrm{a}}$ & $1370 \pm 138^{\mathrm{a}}$ & $1099 \pm 188^{\mathrm{a}}$ \\
\hline Plasma ORAC $(\mu \mathrm{M} \mathrm{TE} / \mathrm{mL})$ & $106.7 \pm 6.8^{a}$ & $102.0 \pm 5.3^{a}$ & $108.8 \pm 11.8^{a}$ & $98.8 \pm 8.2^{a}$ & $98.4 \pm 6.0^{a}$ \\
\hline Liver ORAC $(\mathrm{mM} \mathrm{TE} / \mathrm{g})$ & $3.59 \pm 0.25^{a}$ & $4.16 \pm 0.32^{a}$ & $3.96 \pm 0.35^{a}$ & $3.99 \pm 0.34^{a}$ & $3.88 \pm 0.30^{a}$ \\
\hline
\end{tabular}

Table 6: Blood glucose, final weight, food intake, locomotor activity and ORAC value in plasma and liver of CD-1 mice in different groups, RBC: red blood cells; ORAC: oxygen radical absorbance capacity assay; TE: Trolox equivalents; All values are means \pm SEM $(n=10$, except RER where $n=4)$. Values in the same row with different superscript symbols are significantly different, using LSD test $(\mathrm{P}<0.05)$.

SOD, GSH-px and CAT have been recognized and used in the evaluation of oxidative stress in animal model with hypertension, hyperlipidemia, obesity, and diabetes (Saiki et al. 2007). SOD, is an antioxidant enzyme, converts superoxide radicals $\mathrm{O}_{2} \cdot$ to $\mathrm{H}_{2} \mathrm{O}_{2}$, which will then be converted to $\mathrm{H}_{2} \mathrm{O}$ based on the activity of GSH-px and catalase, thereby protecting the body from oxygen toxicity. From the current results in the red blood cells, after 21 days on experimental diets SOD activity of mice in group 3 (HF $+10 \mathrm{mg} \mathrm{OPH} / \mathrm{g}$ of $\mathrm{HF}$ ) was lower compared to activity of those in group 2 (HF $+1 \mathrm{mg} \mathrm{OPH} / \mathrm{g}$ of $\mathrm{HF})$. It was found that in RBC, SOD level of HF fed mice was lower compare to ND, however supplementation with $100 \mathrm{mg} \mathrm{OPH/g}$ (group 4) 
brought the activity similar to ND group (Figure 29A). This was in agreement with literature data indicating that HF diet cause oxidative stress. The increase of SOD activity in $\mathrm{HF}+100 \mathrm{mg}$ $\mathrm{OPH} / \mathrm{g}$ is likely to detoxify excess $\mathrm{O}_{2}{ }^{-}{ }^{-}$radicals to lesser reactive $\mathrm{H}_{2} \mathrm{O}_{2}$ (Hodgson and Fridovich 1975), after conversion of $\mathrm{O}_{2}{ }^{-}$in to $\mathrm{H}_{2} \mathrm{O}_{2}$ by SOD, CAT and GSH-Px converts $\mathrm{H}_{2} \mathrm{O}_{2}$ to $\mathrm{H}_{2} \mathrm{O}$. Catalase (CAT) activity was determined in red blood cells and it was found that the CAT activity in the RBC samples of mice in groups 3 (HF $+10 \mathrm{mg} \mathrm{OPH} / \mathrm{g}$ of HF), 4 (HF $+100 \mathrm{mg} \mathrm{OPH} / \mathrm{g}$ of $\mathrm{HF}$ ) and ND were similar, but lower than the activity in HF group, and group 2 (HF $+1 \mathrm{mg}$ $\mathrm{OPH} / \mathrm{g}$ of HF) (Figure 29B). One reason could be gradual increase in hydrogen peroxide concentrations (Furukawa et al. 2004). There was a correlation $\mathrm{R}^{2}=0.99$ between increasing amount of OPH and CAT activity; however this correlation was not seen in the SOD activity. A decrease in CAT activity also has been seen in rats that were in hyper and hypo-energetic diet in combination with the antioxidant molecule lycopene (Moreira et al. 2005). 

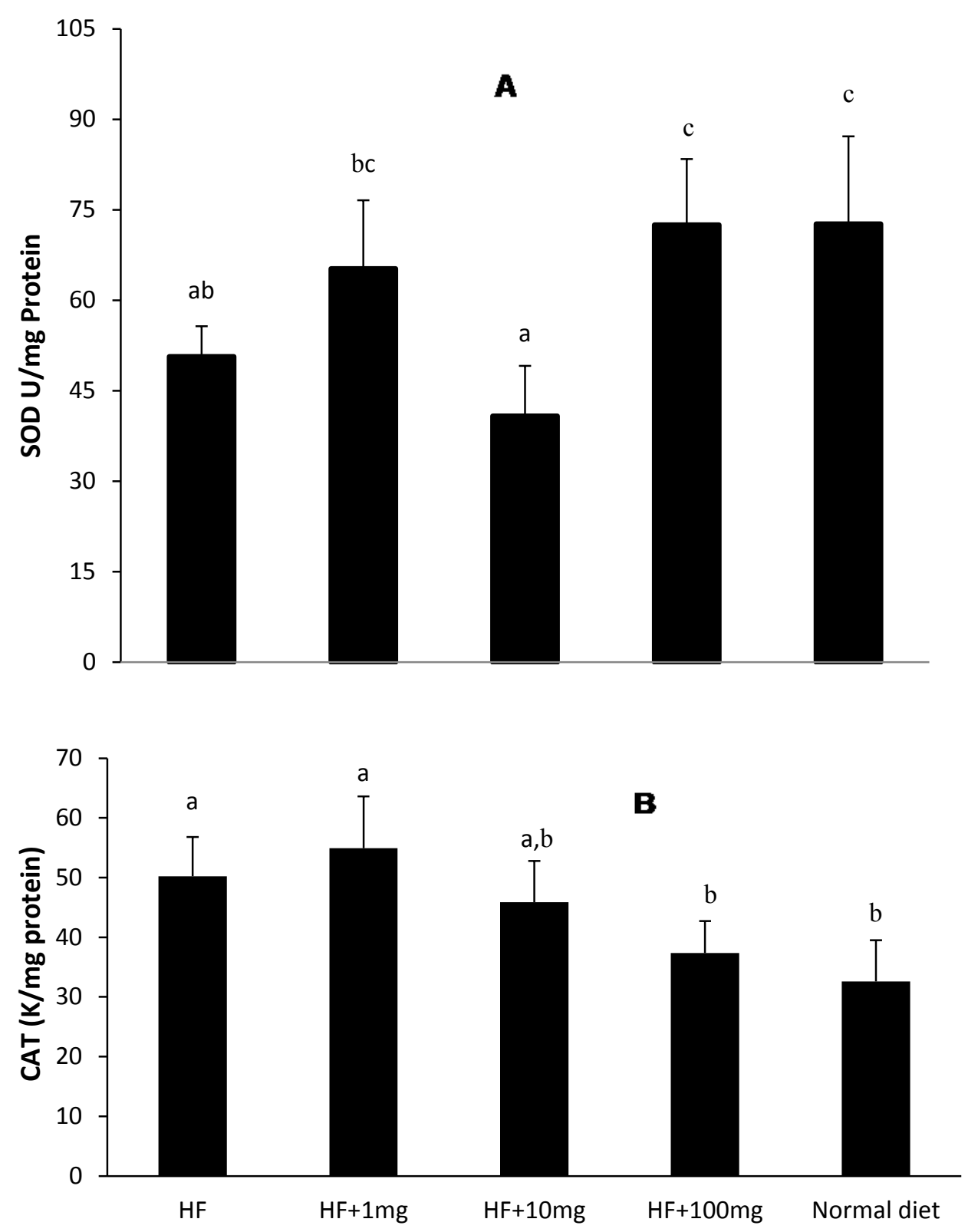

Figure 29: SOD and CAT level in the RBC of CD-1 mice. Group 1 is high fat diet (HF); Group 2 is $\mathrm{HF}+1 \mathrm{mg}$ of oat protein hydrolysate (OPH)/g of HF; Group 3 is $\mathrm{HF}+10 \mathrm{mg} \mathrm{OPH} / \mathrm{g}$ of HF; Group 4 is $\mathrm{HF}+100 \mathrm{mg} \mathrm{OPH} / \mathrm{g}$ of $\mathrm{HF}$ and group 5 is regular mouse chow or normal diet (ND). Statistical differences were evaluated by one-way ANOVA using SPSS 11.0 for windows 7 (SPSS Inc., Chicago). Values with $\mathrm{P}<0.05$ were considered significantly different between the groups using the LSD test (mean \pm standard error). 


\subsection{Effect of OPH on liver}

Increase intake of HF diet has been shown to result in accumulation of fat or ROS production in the liver and this can compromise its ability to regulate body energy homeostasis (Dobrian et al. 2001). An increase of ROS will cause inflammation that could lead to non-alcoholic liver disease (Milagro et al. 2006). It is therefore of interest to investigate if the addition of OPH to HF diet will affect oxidative stress markers of fats in this organ. Results from CD-1 mice in the current study showed $\mathrm{OPH}$ addition had no effect on several markers including total antioxidant capacity (i.e. ORAC), total sulfhydryl groups and peroxides (table 6 and figure 30). Regarding liver peroxides, there are conflicting data in the literature as some studies have reported increased levels in rats fed HF diet (Milagro et al. 2006) while others found no change (Furukawa et al. 2004). In rats on high energy diets supplemented with an antioxidant tomato powder, a decrease in concentration of malondialdehyde, an end product of lipid peroxidation was obtained but no change was observed in CAT activity in rat livers (Moreira et al. 2005).

The effect of OPH on the activity of two antioxidant enzymes SOD and CAT was investigated. SOD activity on mice on HF diet alone was $13.2 \%$ lower than that of those on ND diet confirming the fact that HF increased oxidative stress in the liver (Demori et al. 2006), Addition of $\mathrm{OPH} 100 \mathrm{mg} / \mathrm{g}$ to $\mathrm{HF}$ diet brought SOD activity to $53.0 \pm 1.9$ units/g protein and this was similar ( $\mathrm{p}>0.05)$ to ND level $(57.3 \pm 2.5$ units/mg protein) (Figure $31 \mathrm{~A})$. The activity of SOD (45.3 \pm 2.3 units/ $\mathrm{mg}$ of protein) for mice on $\mathrm{HF}+1 \mathrm{mg} \mathrm{OPH} / \mathrm{g}$ was similar to HF diet only group. However, for reasons non yet clarified, the addition of $10 \mathrm{mg} \mathrm{OPH} / \mathrm{g}$ lowered $(\mathrm{p}<0.05)$ the activity of SOD more than any other group. In a previous study, melon juice extract SOD data are comparable to those of a previous study where a melon juice extract added to HF diet 
fed rats increased their liver Mn-SOD activity to similar level of those rats on the standard diet however, the same study reported that the Cu-Zn SOD activity was lower in in the group of standard diet compared to those on HF diet and melon extract did not affect SOD activity (Décordé et al. 2010). CAT activities in the liver for all the groups were similar except HF $+1 \mathrm{mg}$ OPH/g group that had higher activity (Figure 31B). There were slight increases in peroxide values in $\mathrm{HF}+10 \mathrm{mg} \mathrm{OPH} / \mathrm{g}$ and $\mathrm{HF}+100 \mathrm{mg} \mathrm{OPH} / \mathrm{g}$ groups relative to $\mathrm{HF}+1 \mathrm{mg} \mathrm{OPH} / \mathrm{g}$ which although not significant may explained the higher activity of CAT for mice in $\mathrm{HF}+1 \mathrm{mg}$ $\mathrm{OPH} / \mathrm{g}$ (figure 30). There was no correlation in SOD activity and the amount of OPH added to the HF diet, however CAT activity decreased with a correlation of $\mathrm{R}^{2}=0.83$. Gallic acid has shown to reduce body weight and liver oxidative stress in rats on HF diet by increasing glutathione peroxidase, this enzyme detoxifies peroxides (Hsu and Yen 2007). There was no difference in SOD or CAT activities in the liver of rats in HF high sucrose diet supplemented with polyphenols (Feillet-Coudraya et al. 2009) while bran xylooligosaccharides increased liver SOD activity of rats on HF diet (Wang et al. 2011), Soy protein isolates added diet of obese rats reduced liver oxidative stress by increasing the activity of enzymes involved in lipid metabolism (Aoyama et al. 2000). Different concentrations of the antioxidant molecule chicoric acid showed no effect on the weight organs like heart, lung and brain however, it increased SOD and CAT levels in the liver of mice on HF diet supplemented with chicoric acid $(60 \mathrm{mg} / \mathrm{kg} / \mathrm{d})$ and decreased malondialdehyde (MDA) level, a marker for lipid peroxidation (Xiao et al. 2013). In CD-1 mice used in the present study no difference was found between CAT activities of HF only and ND diet although in other models CAT activity has been found to be lower in HF diet group (Demori et al. 2006). One reason may be that CD-1 mice were on the experimental diet for three weeks compared to four weeks ((Demori et al. 2006). 


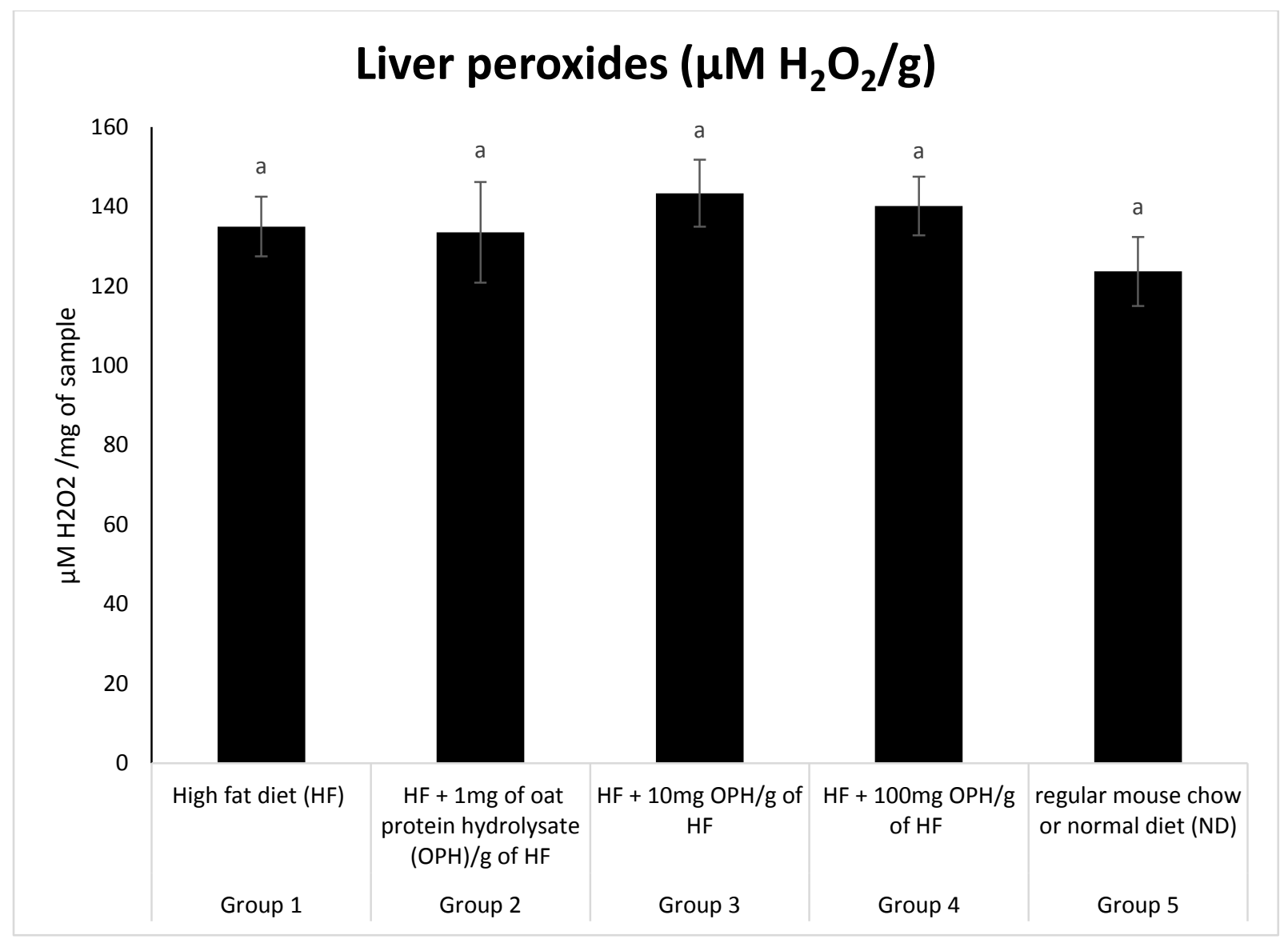

Figure 30: Peroxide level $\left(\mu \mathrm{M} \mathrm{H}_{2} \mathrm{O}_{2} / \mathrm{g}\right)$ from FOX assay in the liver of CD-1 mice. Statistical differences were evaluated by one-way ANOVA using SPSS 11.0 for windows 7 (SPSS Inc., Chicago). Values with $\mathrm{P}<0.05$ were considered significantly different between the groups using the LSD test (mean \pm standard error). 

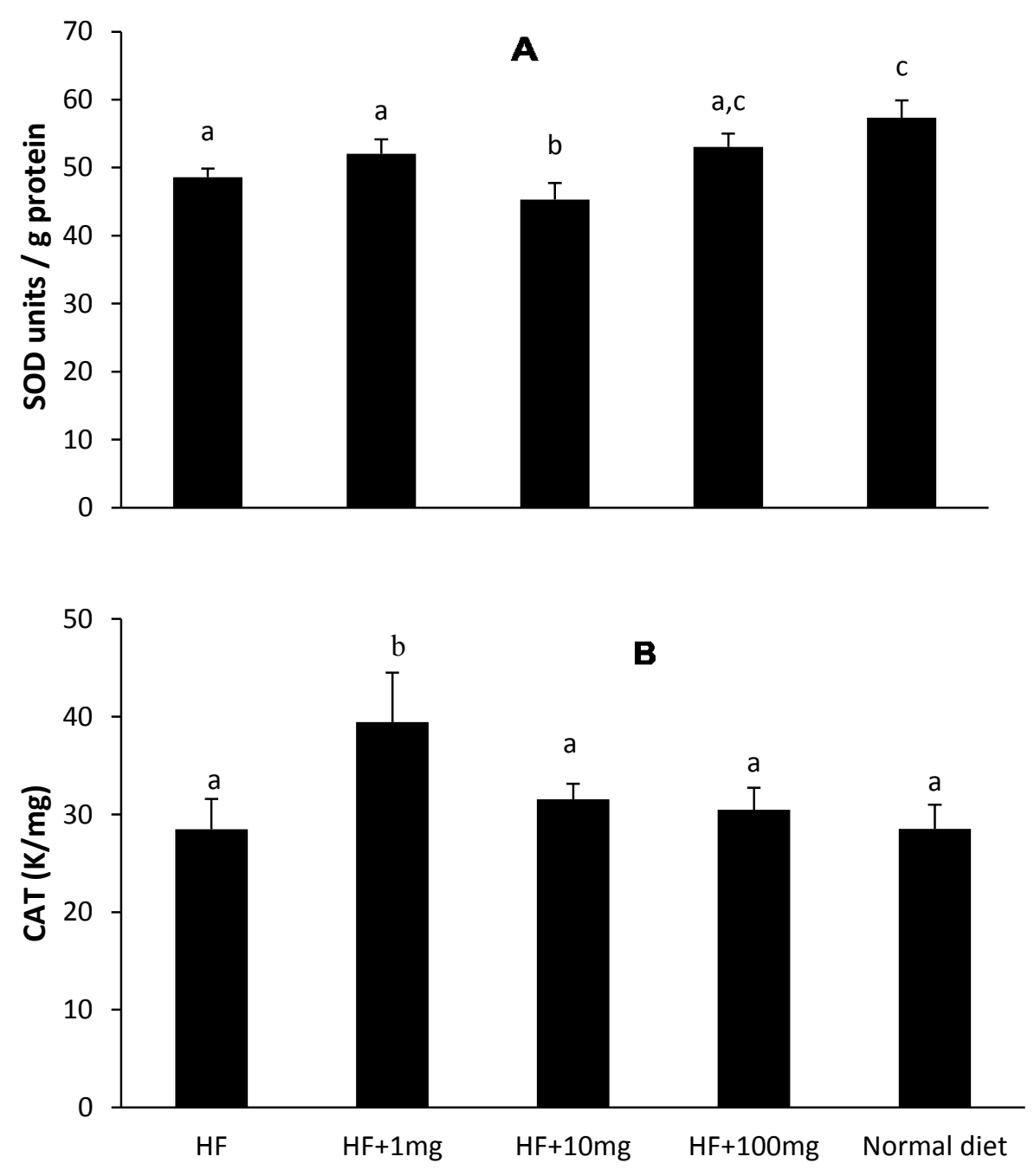

Figure 31: SOD and CAT activity in the liver tissue of CD-1 mice. Statistical differences were evaluated by one-way ANOVA using SPSS 11.0 for windows 7 (SPSS Inc., Chicago). Values with $\mathrm{P}<0.05$ were considered significantly different between the groups using the LSD test (mean \pm standard error). Group 1 is High fat diet (HF); Group 2 is $\mathrm{HF}+1 \mathrm{mg}$ of oat protein hydrolysate (OPH)/g of HF; Group 3 is $\mathrm{HF}+10 \mathrm{mg} \mathrm{OPH} / \mathrm{g}$ of HF; Group 4 is HF + $100 \mathrm{mg}$ $\mathrm{OPH} / \mathrm{g}$ of $\mathrm{HF}$ and group 5 is regular mouse chow or normal diet (ND). 


\subsection{Measurement of Body Weight, Blood Glucose and Respiratory Exchange Ratio}

As it was expected, the average body weight of mice that were on HF diet was higher compared to those on ND, however, supplementation of $\mathrm{OPH}$ to HF diet had no influence on the body weight (table 6). Looking at the energy intake, animals consuming $\mathrm{HF}$ and $\mathrm{HF}+\mathrm{OPH}$ had higher energy intake (kcal/day) compared to CD-1 mice on ND. Figure 32 shows changes in mice weight over the three weeks on experimental and ND diets

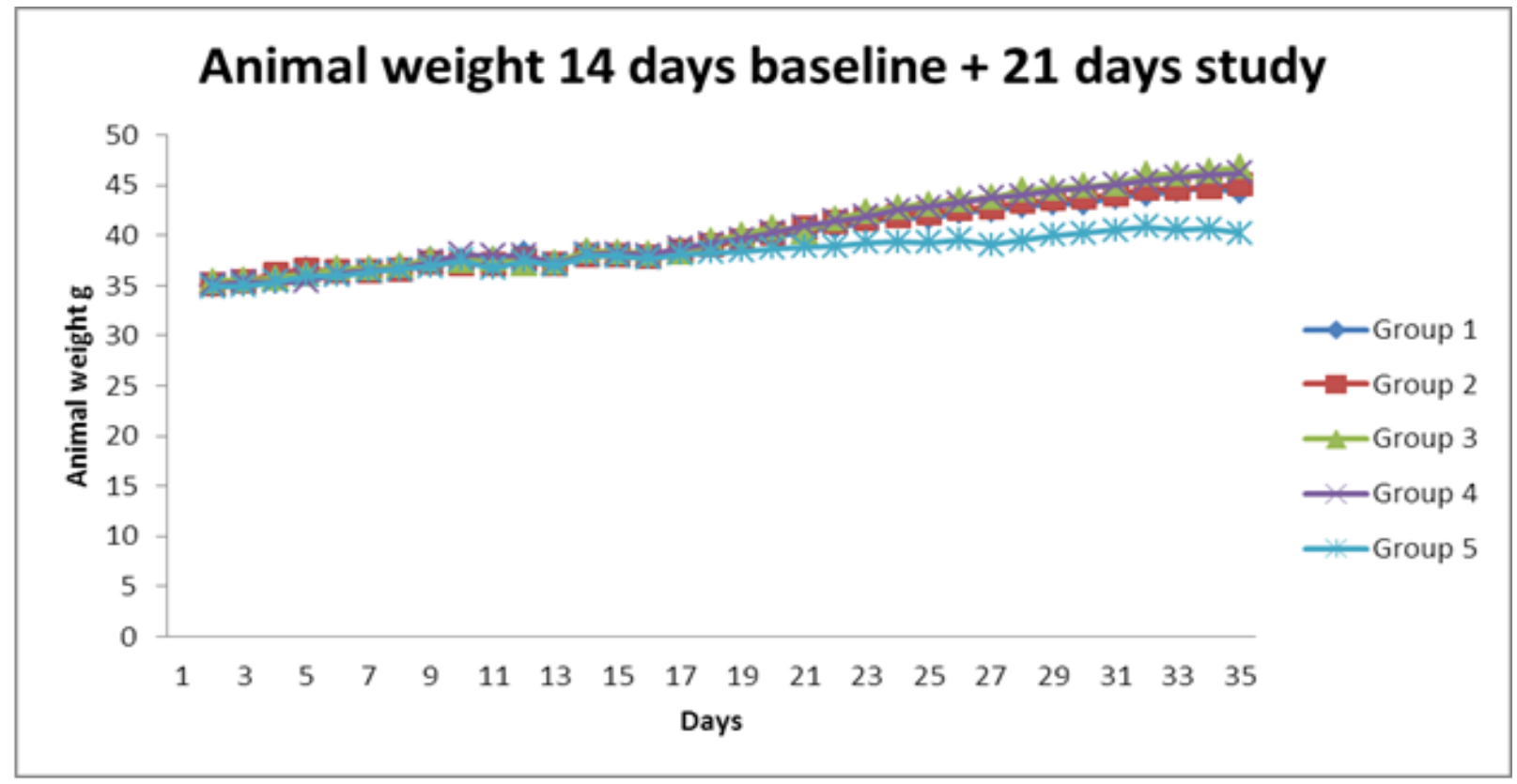

Figure 32: Body weight of the CD-1 mice, during the baseline diet as well as 21 days that animals were on the experimental diet. Group 1 is high fat diet, group 2 is high fat diet $+1 \mathrm{mg}$ $\mathrm{OPH} / \mathrm{g}$ food, group 3 is high fat diet $+10 \mathrm{mg} \mathrm{OPH} / \mathrm{g}$, group 4 is high fat diet $+100 \mathrm{mg} \mathrm{OPH} / \mathrm{g}$, and group 5 is normal diet. 
The ratio of carbohydrate oxidation to lipid oxidation assuming (protein oxidation is negligible) is the respiratory exchange ratio (RER). It is also defined as the volume of $\mathrm{CO}_{2}$ expired $\left(\mathrm{VCO}_{2}\right)$ over the volume of and $\mathrm{O}_{2}$ inspired $\left(\mathrm{VO}_{2}\right)$ is called Respiratory exchange ratio (Martin et al. 2006).

$$
\mathrm{RER}=\mathrm{VCO}_{2} / \mathrm{VO}_{2}
$$

The volume $\mathrm{VCO}_{2}$ or $\mathrm{VO}_{2}$ is derived from the number of moles of oxygen consumed and carbon dioxide exhaled during the production of energy from the two mains groups of energy yielding molecules. When the energy is mainly produced from carbohydrates, the equation and RER values are as followed:

$$
\begin{aligned}
& 6 \mathrm{O}_{2}+\mathrm{C}_{6} \mathrm{H}_{12} \mathrm{O}_{6} \rightarrow 6 \mathrm{CO}_{2}+6 \mathrm{H}_{2} \mathrm{O}+38 \text { ATP } \\
& \mathrm{RER}=\mathrm{VCO}_{2} / \mathrm{VO}_{2}=6 \mathrm{CO}_{2} / 6 \mathrm{O}_{2}=1.0
\end{aligned}
$$

In the case when most energy is from the oxidation fatty acids, the equation and RER are:

$$
\begin{aligned}
& 23 \mathrm{O}_{2}+\mathrm{C}_{16} \mathrm{H}_{32} \mathrm{O}_{2} \rightarrow 16 \mathrm{CO}_{2}+16 \mathrm{H}_{2} \mathrm{O}+129 \text { ATP } \\
& \mathrm{RER}=\mathrm{VCO}_{2} / \mathrm{VO}_{2}=16 \mathrm{CO}_{2} / 23 \mathrm{O}_{2}=0.7
\end{aligned}
$$

In many cases, energy is produced from a combination of fats and carbohydrates. It is therefore not uncommon to find RER values between 0.7 and 1.0. In this study the RER of the twenty animals $(n=4)$ in metabolic chambers (TSE systems, Chesterfield, MO, USA) were measured to see if OPH contribute to changes in body metabolism. Mice on HF diet had an RER value of $0.81 \pm 0.01$ and this was significantly lower compared values on mice in $\mathrm{HF}+10 \mathrm{mg}$ and $\mathrm{HF}+$ $100 \mathrm{mg} \mathrm{OPH} / \mathrm{g}$ suggesting that $\mathrm{OPH}$ prevented metabolic change that was produced by consuming a diet rich in fat. This change was not due to locomotor activity of the CD-1 mice 
(Figure 33). It is unclear whether the increase RER is beneficiary since in some cases increase RER activity could be due to increase in body weight (Seidell et al. 1992). In this study CD-1 mice were on chronic high fat diet that would change the metabolism to utilize the main substrate of the diet (i.e. fats). The change was partly prevented when the HF diet was supplemented with $\mathrm{OPH}$.

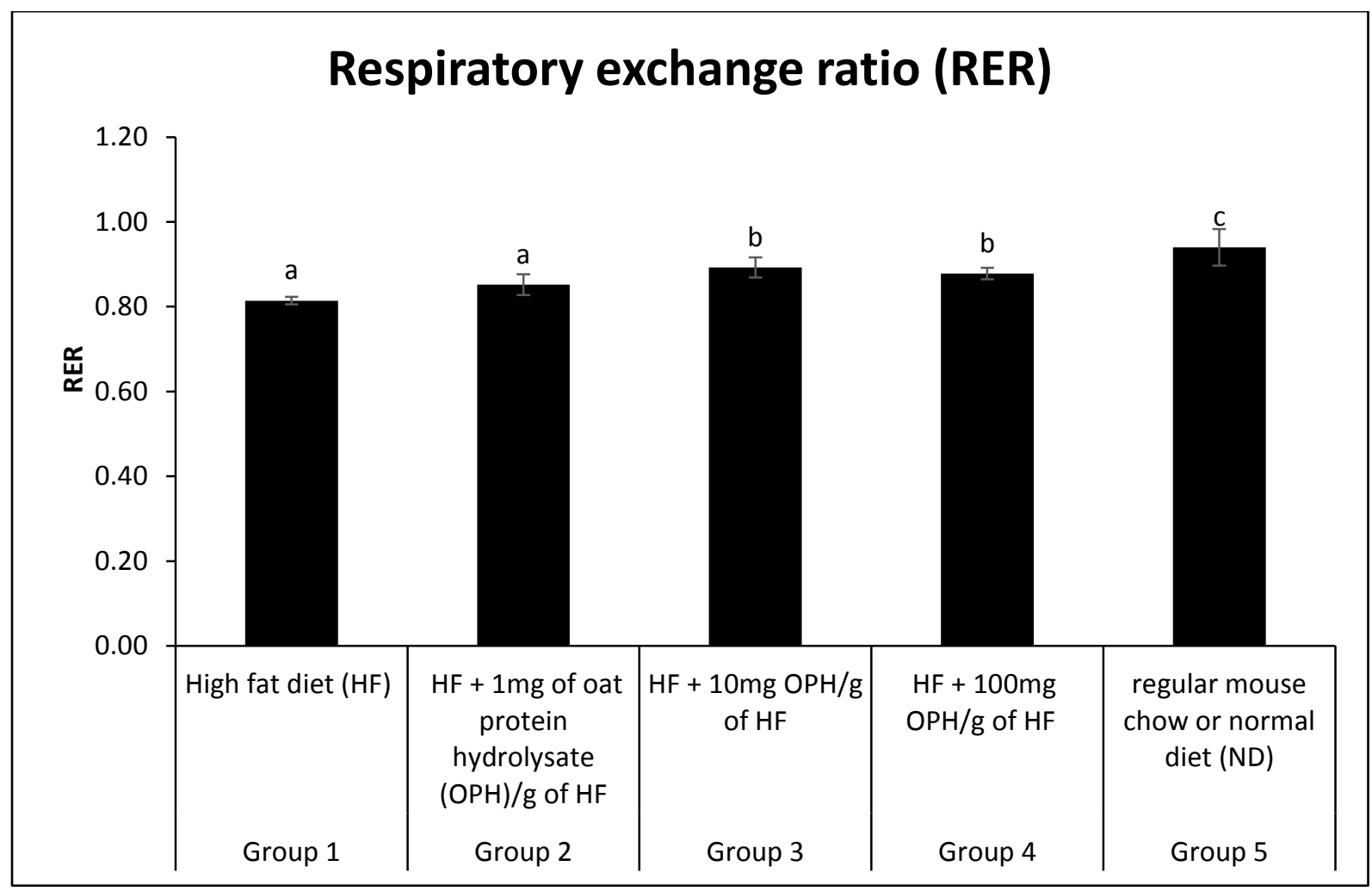

Figure 33: Respiratory exchange ratio of the animals. Statistical differences were evaluated by one-way ANOVA using SPSS 11.0 for windows 7 (SPSS Inc., Chicago). Values with $\mathrm{P}<0.05$ were considered significantly different between the groups using the LSD test (mean $\pm \operatorname{standard}$ error).

Glucose is a source of energy for body's cells, and is transported via blood stream from the intestines or liver to the body's cells, and it is made available for cell absorption via the hormone 
called insulin. Normal glucose level for humans is $5-8 \mathrm{mmol} / \mathrm{L}$ (Del Guerra et al. 2009). According to literature, high fat diet increases the blood glucose compared to the normal diet (de Melo $\mathrm{C}$ et al. 2010). In this study, group 3 (HF $+10 \mathrm{mg} \mathrm{OPH} / \mathrm{g}$ of HF) blood glucose was significantly higher than blood glucose for animals in the other groups $(\mathrm{P}<0.05)$ diet (Figure 34). The blood glucose was measured in non-fasted mice, at the last day of the experiment. Given the results from RER, this could be due to $\mathrm{OPH}$ induced changes in metabolism that increased the utilization of carbohydrates, by easing release of glucose, as well since these mice were not fasted overnight, the change in blood glucose could be due to nutrients consumed recently. 


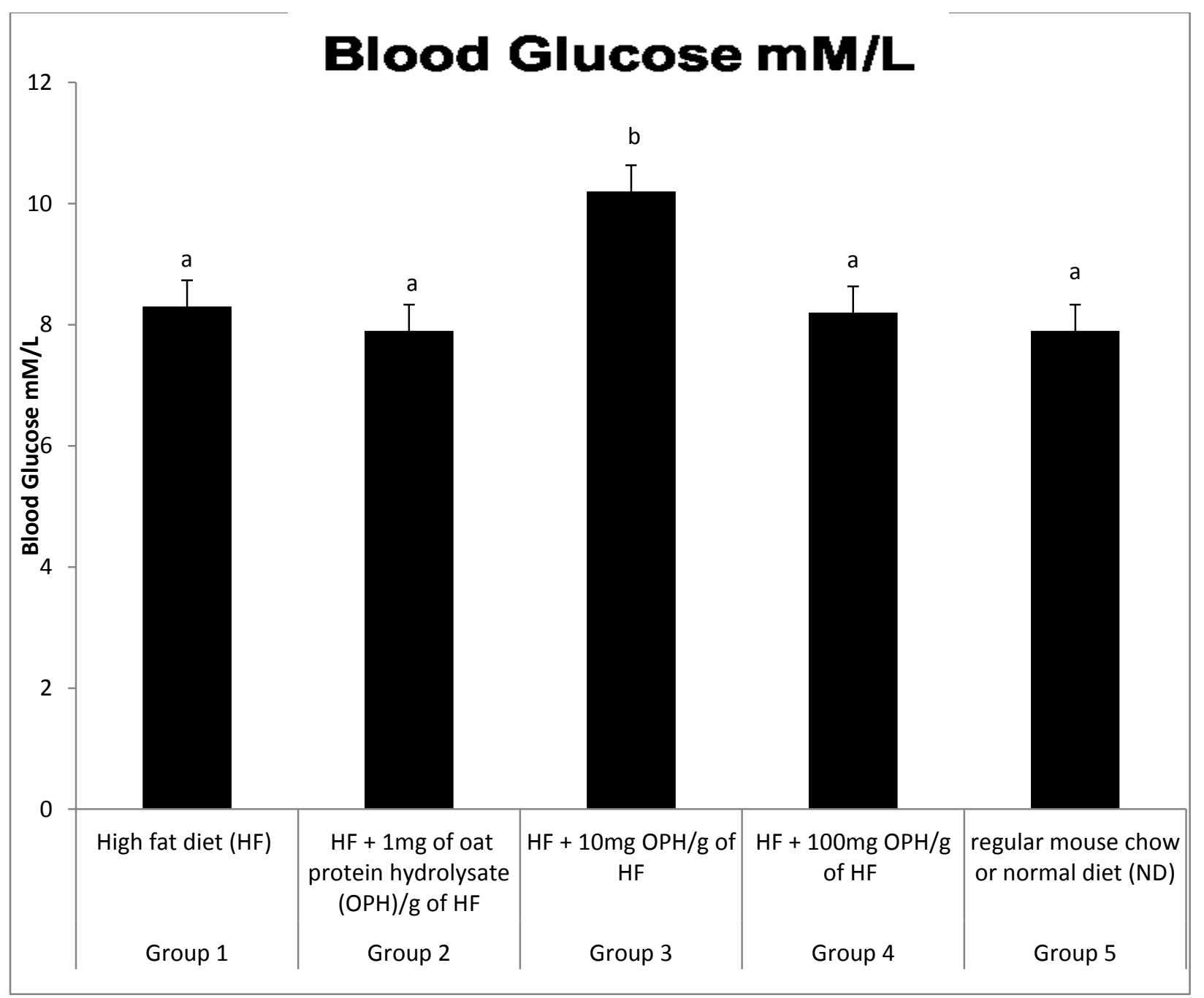

Figure 34: Effect of the OPH on glucose of the mice in $\mathrm{mM} / \mathrm{L}$. Statistical differences were evaluated by one-way ANOVA using SPSS 11.0 for windows 7 (SPSS Inc., Chicago). Values with $\mathrm{P}<0.05$ were considered significantly different between the groups using the LSD test (mean \pm standard error). 


\subsection{Advanced oxidation protein products (AOPPs) level in the brain, plasma, heart, and}

the liver tissue of CD-1 mice.

Advanced oxidation protein products (AOPPs), are terminal products of protein exposure to free radicals and therefore markers of degree of protein damage in oxidative stress (Witko-Sarsat et al. 1996). Studies have shown that AOPP are involved in renal complications (Furuya et al. 2009) and cardiovascular diseases (Marsche et al. 2009). Increased levels of AOPP have also been associated with chronic kidney disease (Witko-Sarsat et al. 1998). In the present study, AOPP levels were significantly lower in brain tissue of mice in group $3(\mathrm{HF}+10 \mathrm{mg} \mathrm{OPH} / \mathrm{g}$ of HF diet) compared to those in group 1 (HFD), group 2 (HF + 1mg OPH/g of HF), group 4 (HF + $100 \mathrm{mg} \mathrm{OPH} / \mathrm{g}$ of $\mathrm{HF}$ ), and normal diet group (figure 35).

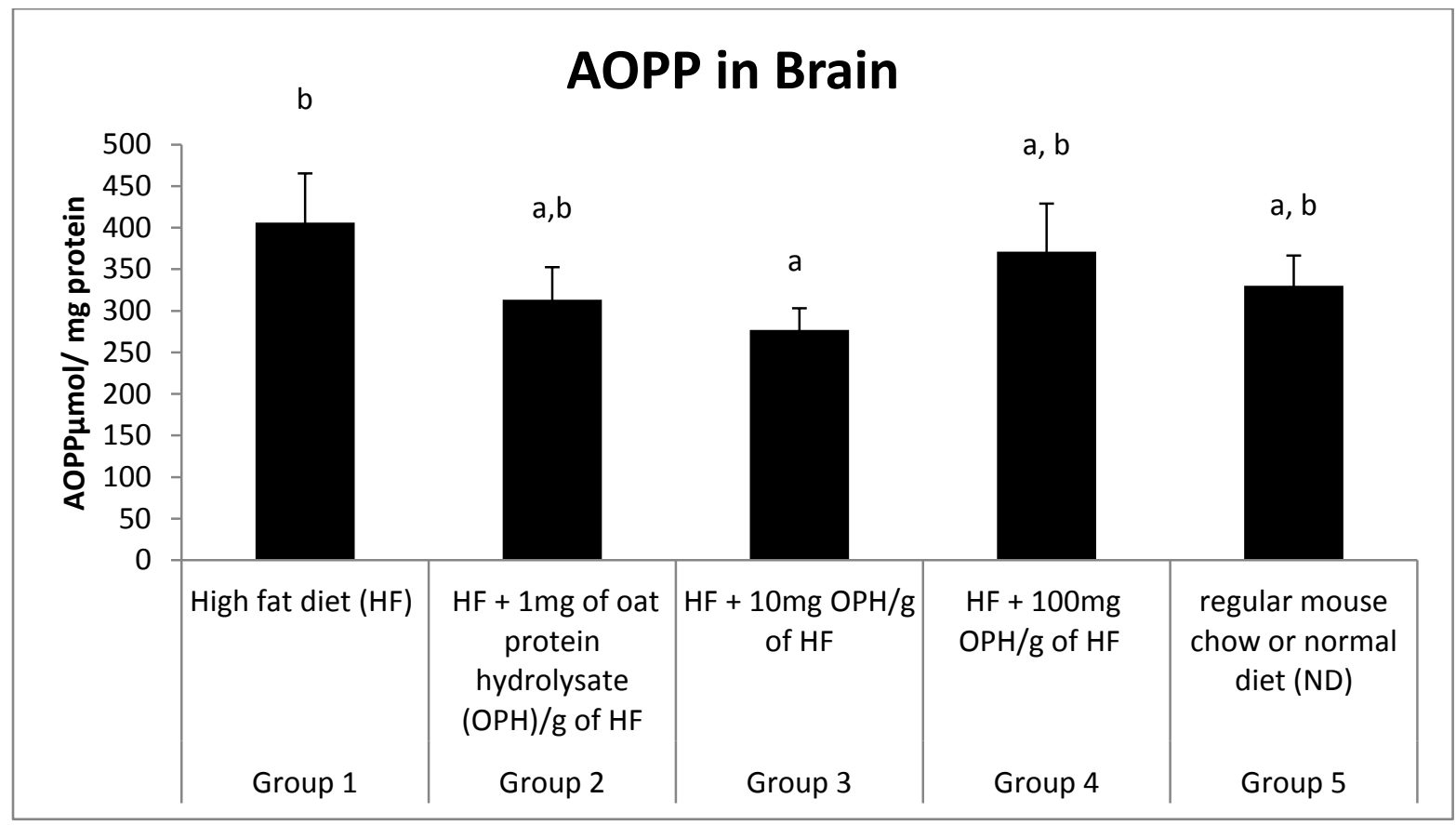

Figure 35: AOPP level in the brain of CD-1 mice in $\mu \mathrm{mol} / \mathrm{mg}$ protein. Statistical differences were evaluated by one-way ANOVA using SPSS 11.0 for windows 7 (SPSS Inc., Chicago). Values with $\mathrm{P}<0.05$ were considered significantly different between the groups using the LSD test (mean \pm standard error). 
Surprisingly, in plasma, AOPP level of mice on normal diet was higher (133 $\mu \mathrm{mol} / \mathrm{mg}$ tissue $)$ compared to HF diet $(159.87 \mu \mathrm{mol} / \mathrm{mg})$. It then appeared that HF diet lowered the oxidation of plasma proteins by $16.8 \%$. The AOPP level was further lowered in animals in group 4 mice (HF $+100 \mathrm{mg} \mathrm{OPH} / \mathrm{g}$ of $\mathrm{HF}$ diet) to $78.23 \mu \mathrm{mol} / \mathrm{mg}$, this value is $41.2 \%$ reduction than group 1 (HFD) (figure 36).

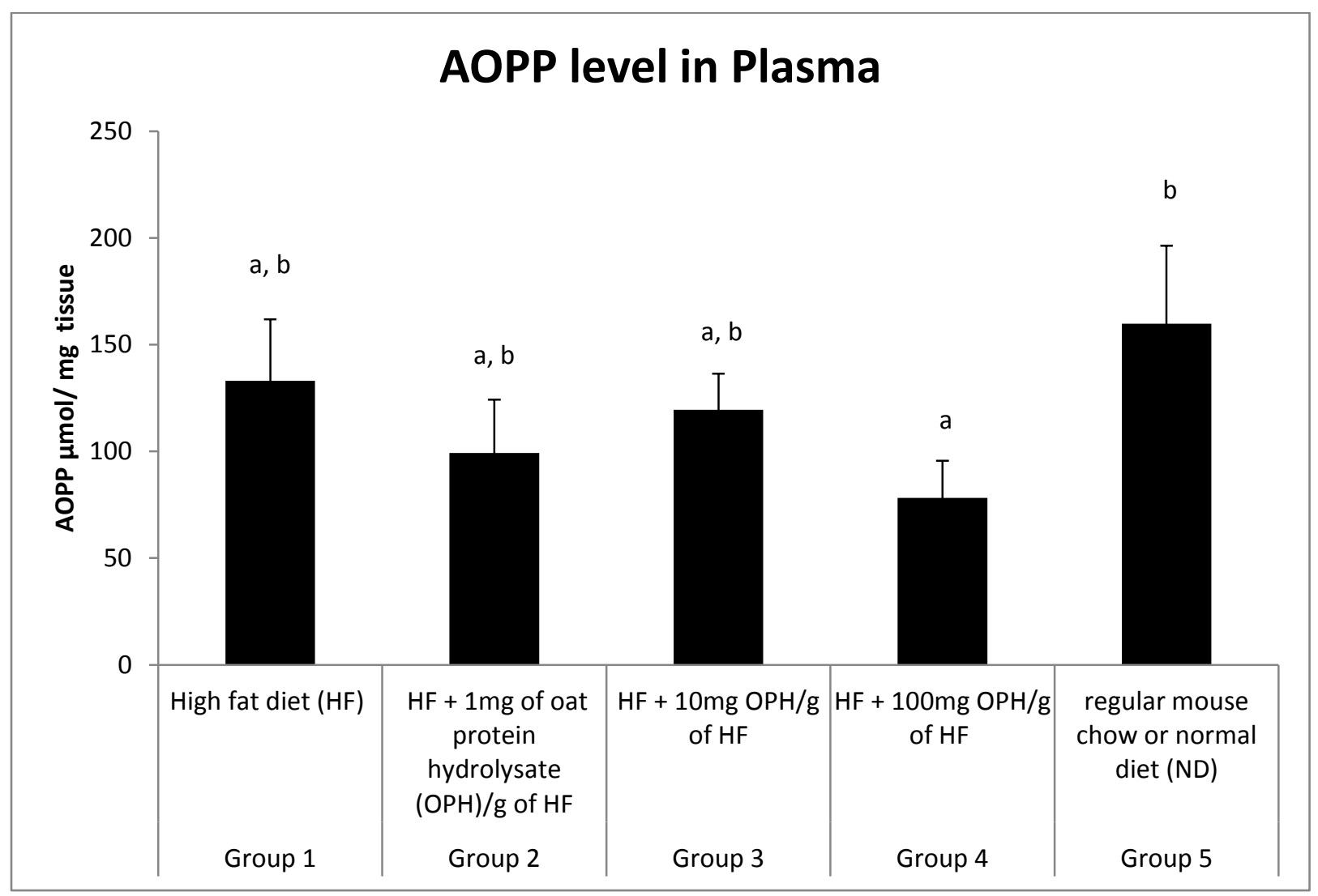

Figure 36: AOPP level in the plasma of CD-1 mice, in $\mu \mathrm{mol} / \mathrm{mg}$ tissue. Statistical differences were evaluated by one-way ANOVA using SPSS 11.0 for windows 7 (SPSS Inc., Chicago). Values with $\mathrm{P}<0.05$ were considered significantly different between the groups using the LSD test (mean \pm standard error). 
Heart AOPP levels were significantly lower in group 3 (HF $+10 \mathrm{mg}$ OPH/g of HF) compare to group 1 (HFD) (figure 37). AOPP level was high in HF diet compare to the normal diet, showing that HF diet increases the AOPP level in the heart, however addition of the $\mathrm{OPH}$ in $1 \mathrm{mg} \mathrm{OPH} / \mathrm{g}$ of HF decreases the AOPP level from $167.78 \mu \mathrm{mol} / \mathrm{mg}$ tissue to $146.51 \mu \mathrm{mol} / \mathrm{mg}$ tissue, about $12.8 \%$ and addition of $10 \mathrm{mg}$ of $\mathrm{OPH} / \mathrm{g}$ of $\mathrm{HF}$ further lowers the AOPP level to $95.58 \mu \mathrm{mol} / \mathrm{mg}$ tissue, the AOPP level decreased by about $43 \%$ however addition of more OPH to the HF diet group 4 ( $100 \mathrm{mg} \mathrm{OPH} / \mathrm{g}$ of HF) increased the AOPP level to $143.45 \mu \mathrm{mol} / \mathrm{mg}$ tissue. AOPP level in the heart of the mice on HF, as well as the AOPP level in the brain of the mice was slightly higher in the HF diet than the ND (figure 35,37 ).

AOPP level in liver was measured however the results were not significantly different (table 7). In a study where they used a melon juice extract, that is rich in superoxide dismutase to see if it will prevent obesity induced by high fat diet in hamsters, The AOPP level in the liver of hamster was measured and it was found that AOPP level in the animals on the HF diet had higher AOPP level compared to the standard diet, and administration of the melon juice extract decreased the AOPP level close to the standard diet animals. The reason for the difference in our result and this research paper is that the animals in the research paper were on the experimental diet for 12 weeks; however, our animals were on the diet for 3 weeks (Décordé et al. 2010). 


\begin{tabular}{|l|l|l|}
\hline Group & & AOPP $\boldsymbol{\mu m o l} / \mathbf{m g}$ tissue \\
\hline 1 & High fat diet & $174.38 \pm 16.60 \mathrm{a}$ \\
\hline 2 & High fat diet $+1 \mathrm{mg}$ & $215.61 \pm 33.11 \mathrm{a}$ \\
\hline 3 & OPH/g food & \\
\hline 4 & OPH/g food & $243.94 \pm 34.89 \mathrm{a}$ \\
\hline 5 & High fat diet $+100 \mathrm{OPH}$ & $231.55 \pm 27.19 \mathrm{a}$ \\
\hline & Normal diet & \\
\hline
\end{tabular}

Table 7: AOPP level in the liver of CD-1 mice. Statistical differences were evaluated by one-way ANOVA using SPSS 11.0 for windows 7 (SPSS Inc., Chicago). Values with $\mathrm{P}<0.05$ were considered significantly different between the groups using the LSD test (mean \pm standard error). 


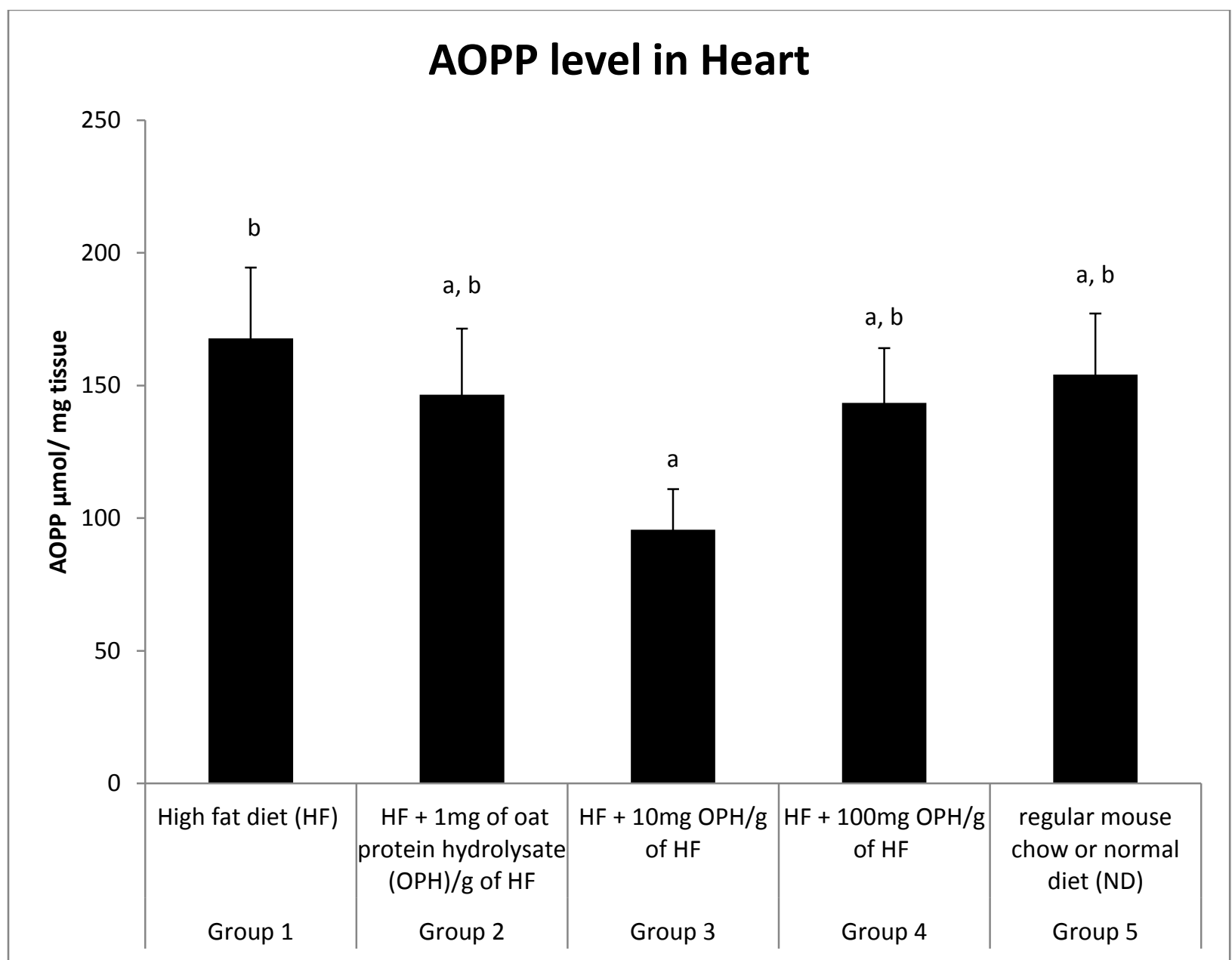

Figure 37: AOPP level in heart of CD-1 mice, in $\mu \mathrm{mol} / \mathrm{mg}$ tissue. Statistical differences were evaluated by one-way ANOVA using SPSS 11.0 for windows 7 (SPSS Inc., Chicago). Values with $\mathrm{P}<0.05$ were considered significantly different between the groups using the LSD test (mean \pm standard error).

\subsection{NO (nitrite + nitrate) level in brain, liver, and the heart tissue.}

$\mathrm{NO}$ is a messenger molecule that functions as a neurotransmitter, and other processes, it is synthesized by NO synthase (NOS) from L-arginine. Impaired production of NO is associated with diseases such as vascular functions. Neurodegenerative disorders, diabetes mellitus, 
cerebral infractions are associated with over production of NO. Reduced levels of NO also are associated with endothelial dysfunction (Mori et al. 2006). In this study the NO (nitrite + nitrate) in $\mu \mathrm{mol} / \mathrm{g}$ tissue was measured using an assay kit. It was found that brain NO levels were significantly higher in group 1 (HFD) compare to rest of the groups. Addition of $1 \mathrm{mg} \mathrm{OPH} / \mathrm{g}$ of HF decreased the NO level from $135.95 \mu \mathrm{mol} / \mathrm{g}$ tissue to $91.66 \mu \mathrm{mol} / \mathrm{g}$ tissue, which is about $32 \%$ lower. The NO level is lower in group $3(\mathrm{HF}+10 \mathrm{mg} \mathrm{OPH} / \mathrm{g}$ of $\mathrm{HF})$ by $37 \%$ compared to the group 1 (HFD). The NO level is increased in group 4 (HF + $100 \mathrm{mg} \mathrm{OPH} / \mathrm{g}$ of HF), to 113.15 $\mu \mathrm{mol} / \mathrm{g}$ tissue, however this value is still lower than $135.95 \mu \mathrm{mol} / \mathrm{g}$ tissue in group 1 (HFD). NO level in ND groups were $94.15 \mu \mathrm{mol} / \mathrm{g}$ tissue, and this value is similar to group 2 ( $\mathrm{HF}+1 \mathrm{mg}$ $\mathrm{OPH} / \mathrm{g}$ of $\mathrm{HF}$ ), and $3(\mathrm{HF}+10 \mathrm{mg} \mathrm{OPH} / \mathrm{g}$ of $\mathrm{HF}) \mathrm{NO}$ level which is $91.66 \mu \mathrm{mol} / \mathrm{g}$ tissue, and $85.51 \mu \mathrm{mol} / \mathrm{g}$ tissue. From this results it can concluded that the NO levels are increased in HF diets compare to ND, however addition of OPH in $1 \mathrm{mg} \mathrm{OPH} / \mathrm{g}$ of $\mathrm{HF}$ diet, and $10 \mathrm{mg} \mathrm{OPH} / \mathrm{g}$ of HF diet decreases the NO level similar to the ND ( figure 38). 


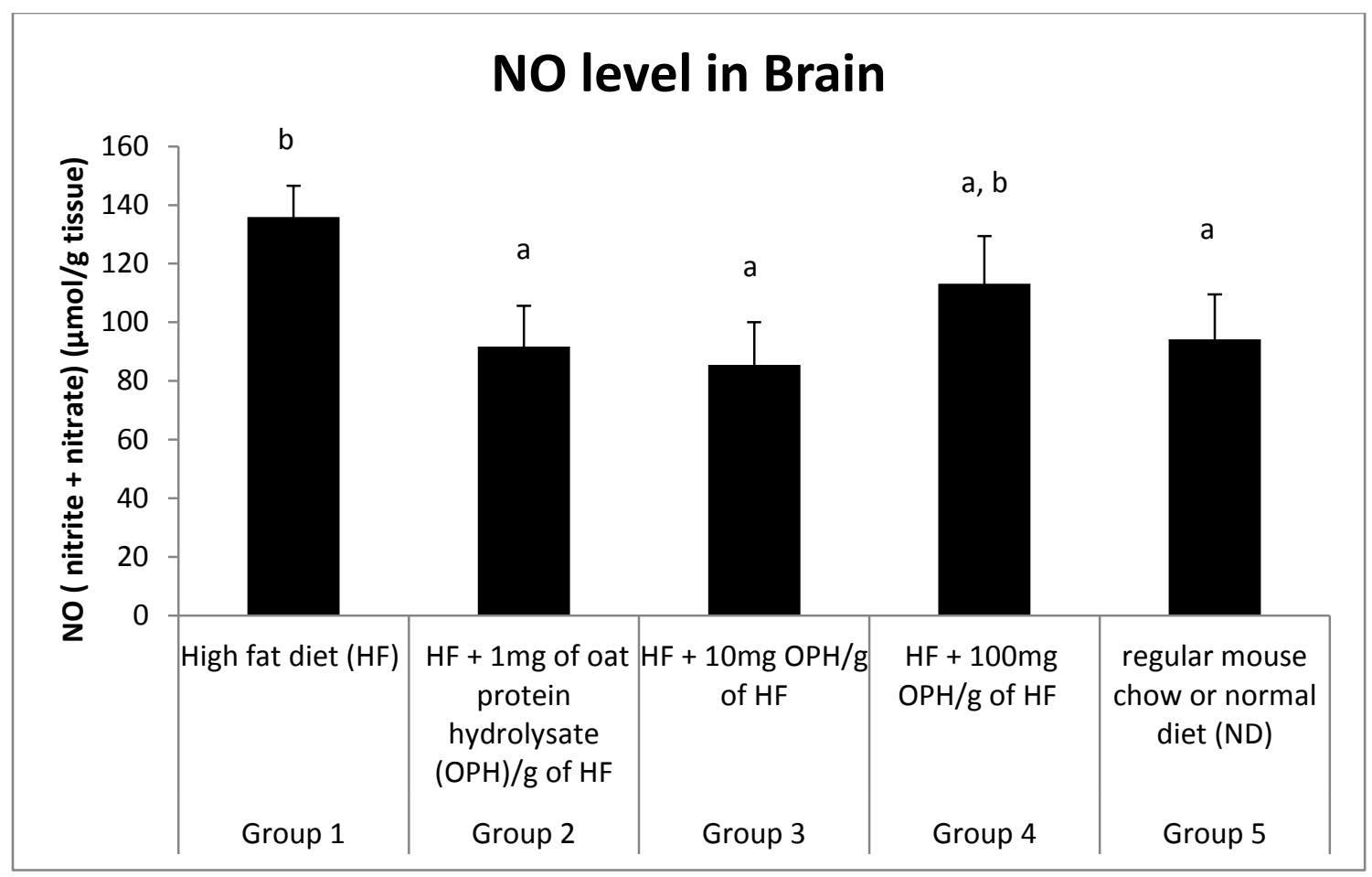

Figure 38: NO (nitrite + nitrate) level in the brain tissue of CD-1 mice in $\mu \mathrm{mol} / \mathrm{g}$ tissue.

Statistical differences were evaluated by one-way ANOVA using SPSS 11.0 for windows 7 (SPSS Inc., Chicago). Values with $\mathrm{P}<0.05$ were considered significantly different between the groups using the LSD test (mean \pm standard error).

Liver NO levels show that animals is group $3(\mathrm{HF}+10 \mathrm{mg} \mathrm{OPH} / \mathrm{g}$ of $\mathrm{HF})$ have higher NO levels compared to the rest of the groups. ND group animals have the lowest NO level, which is 43.01 $\mu \mathrm{mol} / \mathrm{g}$ tissue, and animals on HF diet have NO level of 68.87 which is significantly higher than the animals on ND diet. Addition of $100 \mathrm{mg}$ of OPH/ g HF showed no difference compare to ND (figure 39). 


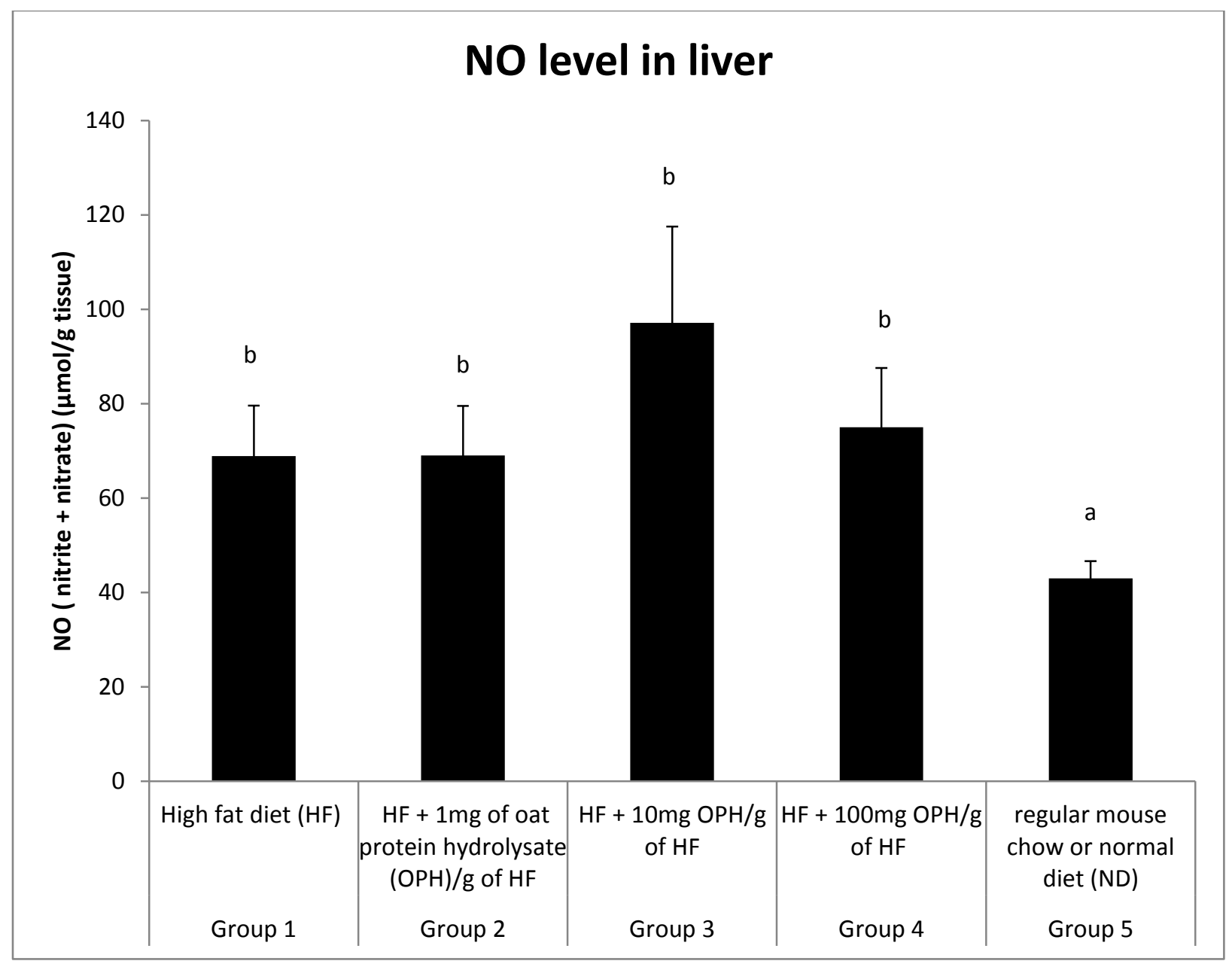

Figure 39: NO (nitrite + nitrate) level in the liver tissue of CD-1 mice in $\mu \mathrm{mol} / \mathrm{g}$ tissue. Statistical differences were evaluated by one-way ANOVA using SPSS 11.0 for windows 7 (SPSS Inc., Chicago). Values with $\mathrm{P}<0.05$ were considered significantly different between the groups using the LSD test (mean \pm standard error).

Heart NO levels, as well as nitrite levels in the heart was measured and it was found that there was no significant difference between the different groups in both NO level as well as nitrite level in the heart tissue (Table 8). 


\begin{tabular}{|l|l|l|l|}
\hline \multicolumn{2}{|l|}{ Group } & $\begin{array}{l}\text { NO ( nitrite + nitrate) } \\
(\mu \mathrm{mol} / \mathrm{g} \text { tissue })\end{array}$ & $\begin{array}{l}\text { Nitrate } \mu \mathrm{mol} / \mathrm{mg} \\
\text { tissue }\end{array}$ \\
\hline 1 & $\begin{array}{l}\text { High fat diet } \\
42.63 \pm 6.40 \mathrm{a}\end{array}$ & $4.04 \pm 5.56 \mathrm{a}$ \\
\hline 3 & $\begin{array}{l}\text { High fat diet }+1 \mathrm{mg} \mathrm{OPH} / \mathrm{g} \\
\text { food fat diet }+10 \mathrm{mg} \mathrm{OPH} / \mathrm{g}\end{array}$ & $64.95 \pm 20.93 \mathrm{a}$ & $4.01 \pm 3.86 \mathrm{a}$ \\
\hline 4 & $\begin{array}{l}\text { High fat diet }+100 \mathrm{mg} \mathrm{OPH} / \mathrm{g} \\
\text { food }\end{array}$ & $44.47 \pm 9.80 \mathrm{a}$ & $3.50 \pm 8.16 \mathrm{a}$ \\
\hline 5 & $\begin{array}{l}\text { Normal diet } \\
\text { food }\end{array}$ & $65.76 \pm 18.27 \mathrm{a}$ & $4.16 \pm 2.88 \mathrm{a}$ \\
\hline
\end{tabular}

Table 8: Nitrite+ nitrate $\mu \mathrm{mol} / \mathrm{g}$ tissue, and Nitrate $\mu \mathrm{mol} / \mathrm{mg}$ tissue in the heart tissue. Statistical differences were evaluated by one-way ANOVA using SPSS 11.0 for windows 7 (SPSS Inc., Chicago). Values with $\mathrm{P}<0.05$ were considered significantly different between the groups using the LSD test (mean \pm standard error).

\subsection{Effect of OPH on oxidative stress markers and vitamins A, E, and $\mathrm{C}$ levels in the brain tissue}

Vitamins $\mathrm{A}, \mathrm{C}$, and $\mathrm{E}$ are essential nutrients that can also play a role in oxidative stress. In a previous study, the effect of vitamin A, E, C and E+C (15 mg/kg of body weight) on brain oxidative stress was investigated in rats exposed to restraint stress (Zaidi and Banu 2004). It was found that restraint stress resulted in a decrease of GSH concentration and activities of SOD, GST and catalase and that both pre-stress and post-stress vitamin treatments (alone or combined) resulted in alteration of these parameters towards their control values (Zaidi and Banu 2004). In vivo biological anti-oxidative properties of $\mathrm{OPH}$ in brain or other organs can therefore preserve the amount of these vitamins. 
Oxygen radical absorbance capacity (ORAC), peroxides levels, total thiols, vitamins, A, E, and $\mathrm{C}$ levels in the brain tissues were not significantly different between the groups $(\mathrm{P}<0.05)$ (table $9,10)$.

\begin{tabular}{|c|c|c|c|c|}
\hline \multicolumn{2}{|c|}{ Group } & $\begin{array}{l}\text { FOX } \mu \mathrm{M} \quad \mathrm{H}_{2} \mathrm{O}_{2} \\
/ \mathrm{mg} \text { of sample }\end{array}$ & $\begin{array}{l}\text { Total GSH }(\mu \mathrm{M} \\
\text { cysteine/ } \mathrm{mL})\end{array}$ & $\begin{array}{l}\text { ORAC Value } \\
\text { Trolox } \mu \mathrm{M} u \mathrm{~L} / \mathrm{g}\end{array}$ \\
\hline 1 & High fat diet & $13.24 \pm 3.04 \mathrm{a}$ & $5.30 \pm 0.42 \mathrm{a}$ & $10.16 \pm 1.16 \mathrm{a}$ \\
\hline 2 & $\begin{array}{l}\text { High fat diet }+ \\
1 \mathrm{mg} \mathrm{OPH} / \mathrm{g} \text { food }\end{array}$ & $14.67 \pm 2.52 \mathrm{a}$ & $5.05 \pm 0.29 \mathrm{a}$ & $9.82 \pm 0.80 \mathrm{a}$ \\
\hline 3 & $\begin{array}{l}\text { High fat diet }+ \\
10 \mathrm{mg} \mathrm{OPH} / \mathrm{g} \\
\text { food }\end{array}$ & $13.36 \pm 1.76 \mathrm{a}$ & $4.61 \pm 0.24 \mathrm{a}$ & $9.47 \pm 1.02 \mathrm{a}$ \\
\hline 4 & $\begin{array}{l}\text { High fat diet }+ \\
100 \mathrm{mg} \mathrm{OPH} / \mathrm{g} \\
\text { food }\end{array}$ & $12.62 \pm 2.23 \mathrm{a}$ & $5.07 \pm 0.45 \mathrm{a}$ & $9.76 \pm 1.32 \mathrm{a}$ \\
\hline 5 & Normal diet & $13.05 \pm 1.53 \mathrm{a}$ & $5.14 \pm 0.33 \mathrm{a}$ & $10.58 \pm 0.91 \mathrm{a}$ \\
\hline
\end{tabular}

Table 9: Peroxide level, total GSH and the ORAC value in the brain tissue of CD-1 mice.

Statistical differences were evaluated by one-way ANOVA using SPSS 11.0 for windows 7 (SPSS Inc., Chicago). Values with $\mathrm{P}<0.05$ were considered significantly different between the groups using the LSD test (mean \pm standard error). 


\begin{tabular}{|l|l|l|l|l|}
\hline \multicolumn{2}{|l|}{ Group } & $\begin{array}{l}\text { Vitamin A } \\
\boldsymbol{\mu g} / \mathbf{g} \text { of tissue }\end{array}$ & $\begin{array}{l}\text { Vitamin E } \mu \mathrm{g} / g \\
\text { of tissue }\end{array}$ & $\begin{array}{l}\text { Vitamin C } \mu g / g \\
\text { of tissue }\end{array}$ \\
\hline 1 & High fat diet & $6.27 \pm 0.34 \mathrm{a}$ & $6.35 \pm 0.28 \mathrm{a}$ & $1101 \pm 94.20 \mathrm{a}$ \\
\hline 2 & $\begin{array}{l}\text { High fat diet }+1 \mathrm{mg} \\
\text { OPH/g food }\end{array}$ & $5.72 \pm 0.48 \mathrm{a}$ & $5.36 \pm 0.30 \mathrm{a}$ & $1282 \pm 135.58 \mathrm{a}$ \\
\hline 3 & $\begin{array}{l}\text { High fat diet }+10 \mathrm{mg} \\
\text { OPH/g food }\end{array}$ & $6.55 \pm 0.48 \mathrm{a}$ & $5.41 \pm 0.25 \mathrm{a}$ & $1307 \pm 135.30 \mathrm{a}$ \\
\hline 4 & $\begin{array}{l}\text { High fat diet }+100 \\
\mathrm{mg} \text { OPH/g food }\end{array}$ & $6.01 \pm 0.62 \mathrm{a}$ & $5.79 \pm 0.40 \mathrm{a}$ & $1370 \pm 70.07 \mathrm{a}$ \\
\hline 5 & Normal diet & $6.16 \pm 0.45 \mathrm{a}$ & $5.38 \pm 0.29 \mathrm{a}$ & $1199.19 \pm 102.41 \mathrm{a}$ \\
\hline
\end{tabular}

Table 10: Vitamin A, E, and C $\mu \mathrm{g} / \mathrm{g}$ of tissue, in brain tissue of CD-1 mice. Statistical

differences were evaluated by one-way ANOVA using SPSS 11.0 for windows 7 (SPSS Inc., Chicago). Values with $\mathrm{P}<0.05$ were considered significantly different between the groups using the LSD test (mean \pm standard error).

\subsection{Vitamin A, Vitamin A palmitate, Retinol equivalent level, and vitamins $\mathbf{C}, \mathbf{E}$ level in the liver tissue of CD-1 mice}

Vitamin A level in the animal liver was measured and it showed that animals on group 5 (ND) had the highest vitamin A compared to the rest of the groups. Animals in group 1 or the HF group had slightly higher vitamin A compared to the animal that the OPH was added to their diet, but this finding was not significantly different (Figure 40). 


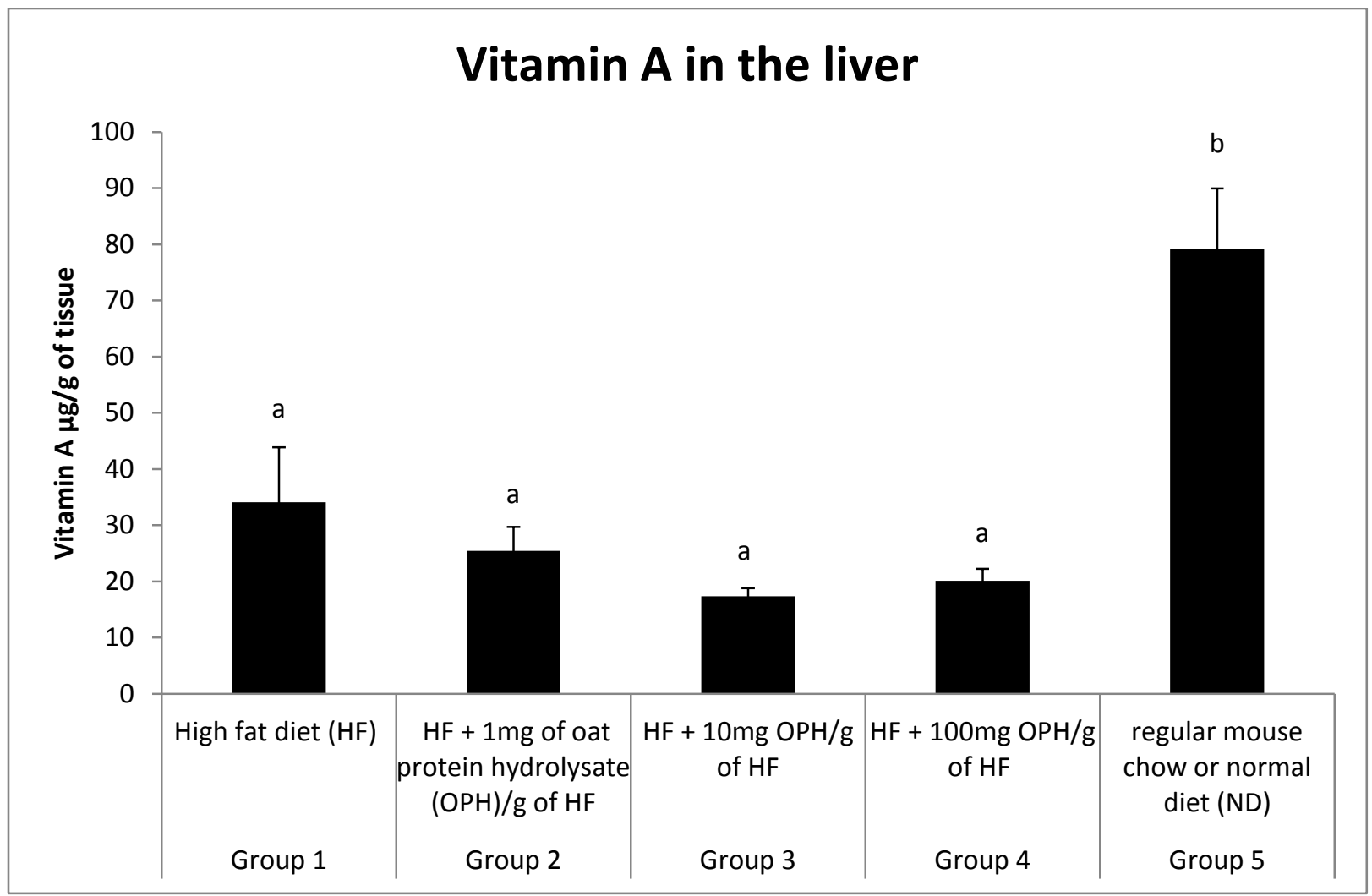

Figure 40: Vitamin A ( $\mu \mathrm{g} / \mathrm{g}$ of tissue) level in the liver tissue of CD-1 mice. Statistical differences were evaluated by one-way ANOVA using SPSS 11.0 for windows 7 (SPSS Inc., Chicago). Values with $\mathrm{P}<0.05$ were considered significantly different between the groups using the LSD test (mean \pm standard error).

Vitamin A palmitate in the liver samples showed that group 5 (ND) animals had the highest vitamin A palmitate, compared to the rest of the groups, and HF diet lowered the vitamin A palmitate level in the liver samples by $14 \%$ compared to the ND, and addition of the $1 \mathrm{mg}$ OPH/g of food lowered the vitamin A plamitate level from $619.11 \mu \mathrm{g} / \mathrm{g}$ of tissue to $445.53 \mu \mathrm{g} / \mathrm{g}$ of tissue, which is $28 \%$ lower compare to the HF diet and, addition of $10 \mathrm{mg} \mathrm{OPH} / \mathrm{g}$ of $\mathrm{HF}$ food and $100 \mathrm{mg} \mathrm{OPH} / \mathrm{g}$ of HF food had similar vitamin A palmitate to the HF group (Figure 41). 


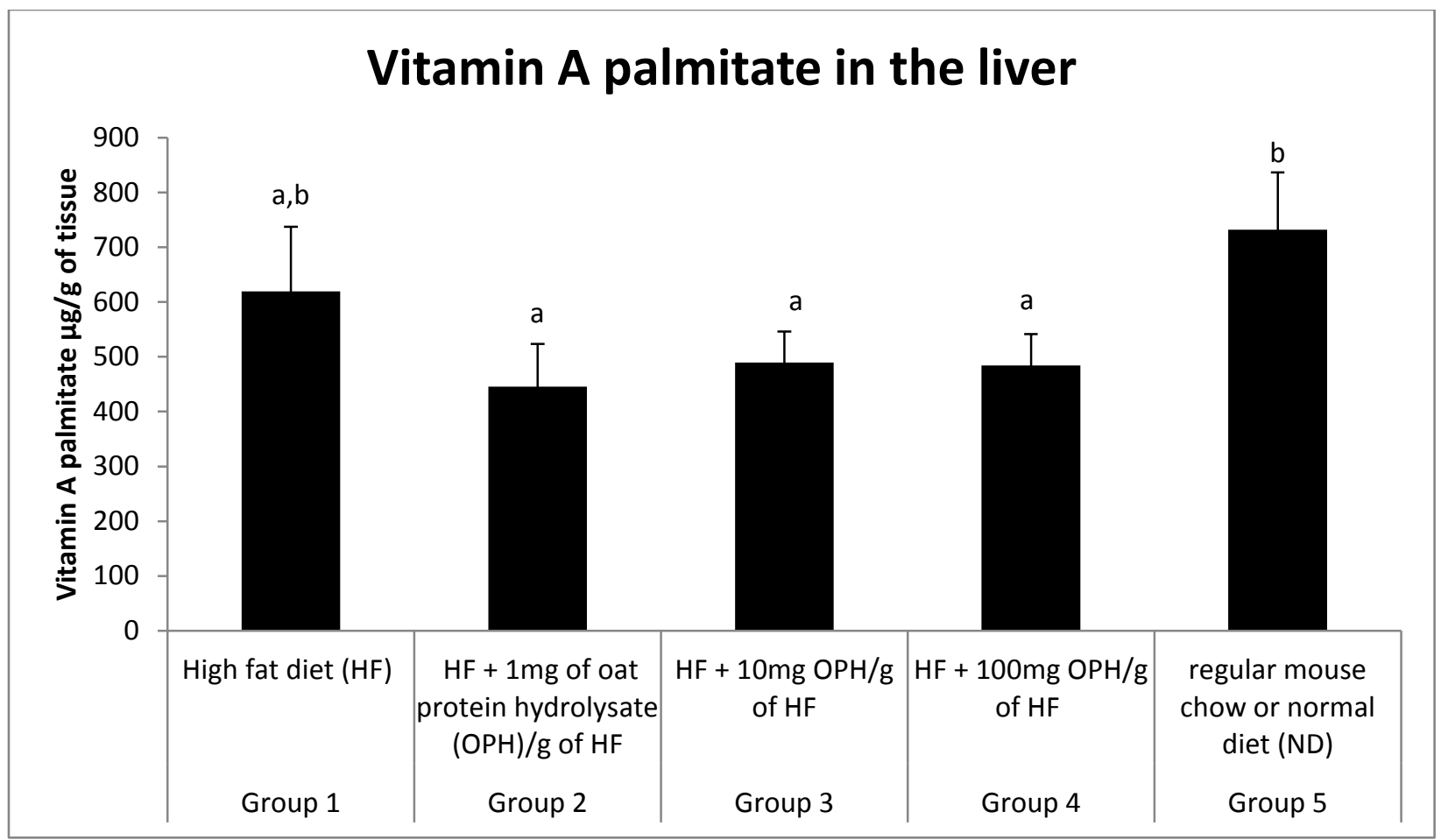

Figure 41: Vitamin A palmitate level in the mice liver. Statistical differences were evaluated by one-way ANOVA using SPSS 11.0 for windows 7 (SPSS Inc., Chicago). Values with $\mathrm{P}<0.05$ were considered significantly different between the groups using the LSD test (mean $\pm \operatorname{standard}$ error).

Measurement of retinol equivalent level in the liver samples showed that ND had the highest retinol level in the liver, and HF diet lowered the retinol level from $478.6 \mu \mathrm{g} / \mathrm{g}$ of tissue to $371.99 \mu \mathrm{g} / \mathrm{g}$ of tissue or by $22 \%$. Addition of OPH had no effect in the retinol level in the liver tissue (Figure 42). 


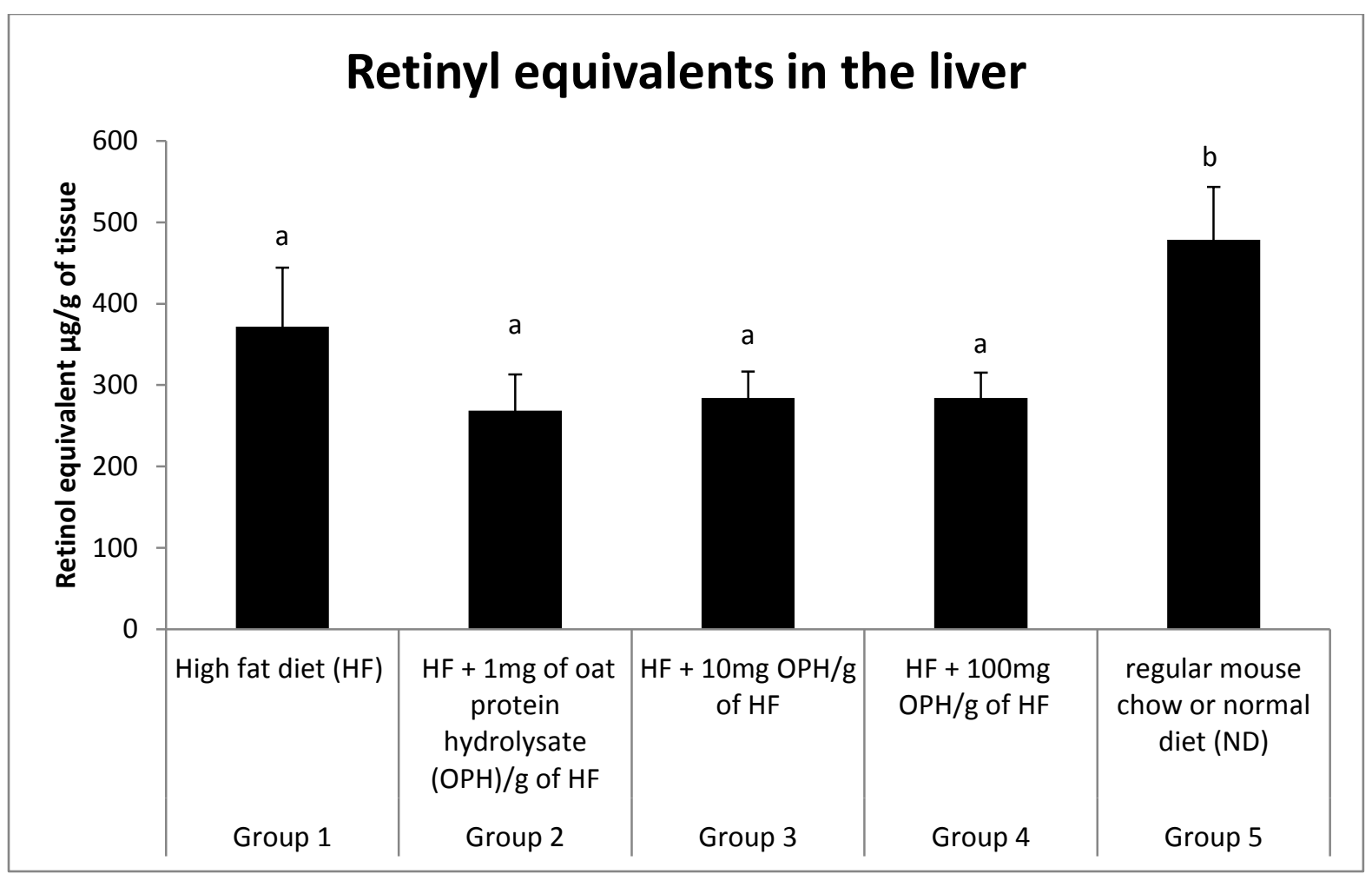

Figure 42: Retinyl equivalent levels in the liver. Statistical differences were evaluated by oneway ANOVA using SPSS 11.0 for windows 7 (SPSS Inc., Chicago). Values with $\mathrm{P}<0.05$ were considered significantly different between the groups using the LSD test (mean \pm standard error).

In my study, vitamin C measurement in the liver tissue showed that both group 1 (HFD) and group 5 (ND) had similar vitamin $\mathrm{C}$ level in the liver tissue; and addition of the $\mathrm{OPH}$ to the $\mathrm{HF}$ diet increased the vitamin $\mathrm{C}$ level in the liver tissue. Group 5 (ND) animals had vitamin $\mathrm{C}$ level of $484.57 \pm 16.96 \mu \mathrm{g} / \mathrm{g}$ tissue, and group 1 (HFD) had vitamin C level of $466.89 \pm 20.38 \mu \mathrm{g} / \mathrm{g}$ tissue. Addition of the $\mathrm{OPH}$ in $1 \mathrm{mg} \mathrm{OPH} / \mathrm{g}$ of $\mathrm{HF}$ food, $10 \mathrm{mg} \mathrm{OPH} / \mathrm{g}$ of $\mathrm{HF}$ food, and $100 \mathrm{mg}$ $\mathrm{OPH} / \mathrm{g}$ of HF food increased the vitamin $\mathrm{C}$ level to $646.2 \pm 27.06 \mu \mathrm{g} / \mathrm{g}$ tissue, $627.47 \pm 26.86 \mu \mathrm{g} / \mathrm{g}$ tissue, and $623.07 \pm 30.06 \mu \mathrm{g} / \mathrm{g}$ tissue respectively. Figure 44 represents the vitamin $\mathrm{C}$ level in the liver tissue. Since supplementation of OPH increased the vitamin C levels in the liver tissue, it 
can be concluded that some peptides in $\mathrm{OPH}$ with radical scavenging activities may be bioavailable and this resulted in preserve of vitamin C. Alternatively, OPH may have been further digested into antioxidant amino acids that was absorbed and produced the observed results.

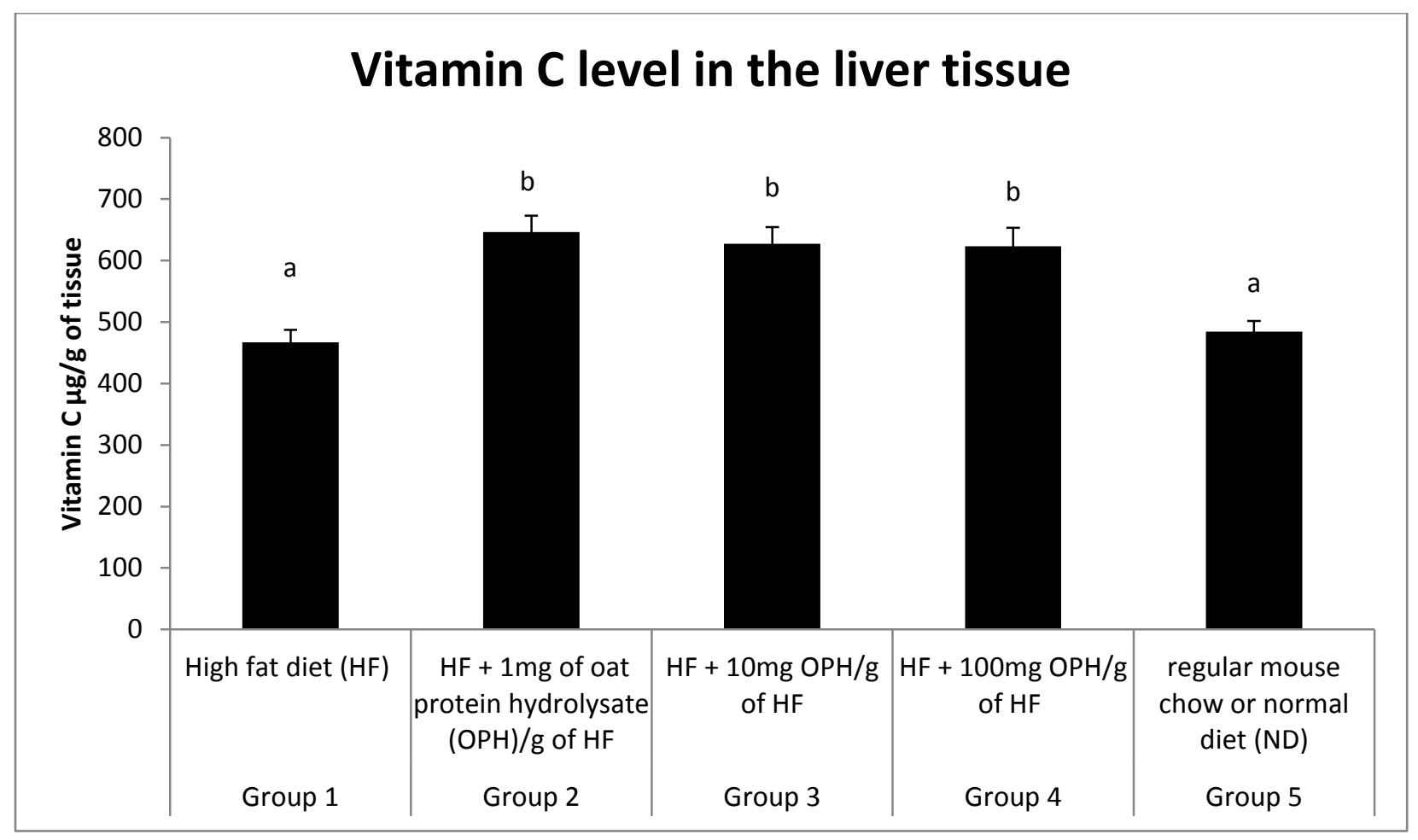

Figure 43: This figure represents the vitamin C level in the liver tissue of CD-1 mice. Statistical differences were evaluated by one-way ANOVA using SPSS 11.0 for windows 7 (SPSS Inc., Chicago). Values with $\mathrm{P}<0.05$ were considered significantly different between the groups using the LSD test (mean \pm standard error).

Vitamin E protects membranes from free radicals, and it turns in to a vitamin $\mathrm{E}$ radical. There is evidence that vitamin $\mathrm{E}$ and Ascorbate interact together, and Ascorbate regenerates vitamin $\mathrm{E}$ 
from vitamin $\mathrm{E}$ radical. In this study, vitamin $\mathrm{E}$ level in the liver tissue was measured and it was that group 5 (ND) animals had the lowest vitamin E in their liver tissue. Animals in group 1 (HFD) had vitamin E level of $57.3 \pm 8.42 \mu \mathrm{g} / \mathrm{g}$ of tissue and group 5 (ND) animals had vitamin E level of $28.33 \pm 8.5 \mu \mathrm{g} / \mathrm{g}$ of tissue. Group 5 (ND) had 50\% lower vitamin E in their liver compared to group 1 (HFD). Addition of OPH to the animal diet increased the vitamin E level in the animal liver, however the increased compared to the HF diet was not significant, but compare to the ND diet it was significant. Figure 45 represent the animal vitamin E level in the liver tissue. Since the vitamin E level was higher in all groups that were on high fat diet, it can be concluded that the high fat diet contains vitamin $\mathrm{E}$, and this can be the reason for the increase of the vitamin $\mathrm{E}$, in group 1,2,3, and 4. The high fat diet was based on AIN-93 formulation and this diet contains $15.0 \mathrm{~g} / \mathrm{kg}$ of vitamin $\mathrm{E}$.

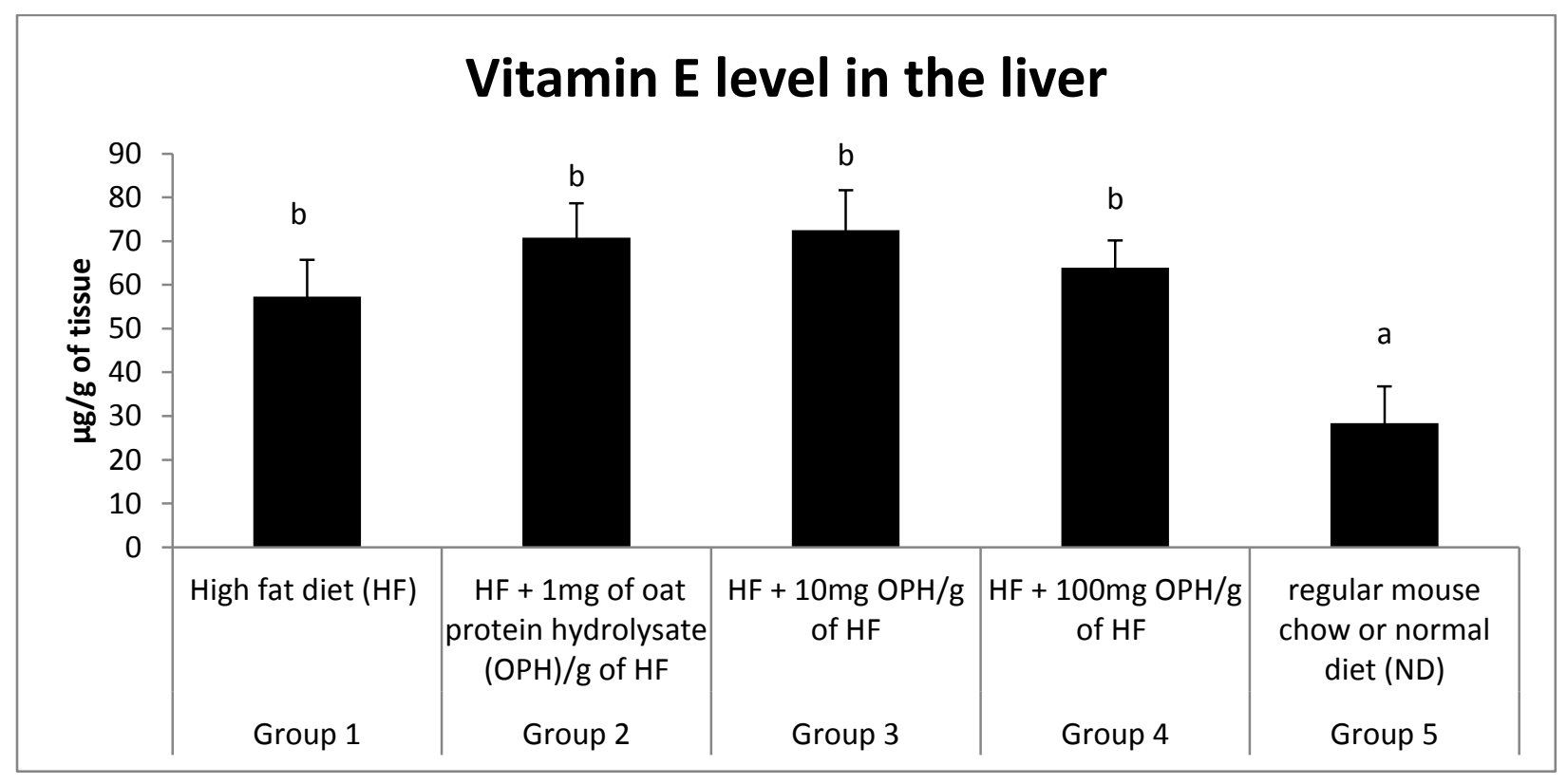

Figure 44: Vitamin E level in the liver tissue of CD-1 mice. Statistical differences were evaluated by one-way ANOVA using SPSS 11.0 for windows 7 (SPSS Inc., Chicago). Values with $\mathrm{P}<0.05$ were considered significantly different between the groups using the LSD test (mean \pm standard error). 


\subsection{Vitamin A, vitamin E, retinol equivalents and vitamin $C$ levels in the lung tissue of}

\section{CD-1 mice}

Vitamin A, vitamin E, retinol equivalents and vitamin $\mathrm{C}$ levels in the lung tissue was measured and it was found that there was no difference between the different groups (table 11). However vitamin A palmitate level in the lung tissue showed that group 1 (HFD) animals had the highest vitamin A palmitate level in the lung tissue. Addition of the $1 \mathrm{mg}$ of OPH/ $\mathrm{g}$ of $\mathrm{HF}$ food lowered the vitamin A palmitate level from $61.99 \mu \mathrm{g} / \mathrm{g}$ of tissue to $28.61 \mu \mathrm{g} / \mathrm{g}$ of tissue, and addition of $10 \mathrm{mg}$ of $\mathrm{OPH} / \mathrm{g}$ of $\mathrm{HF}$ food increased the vitamin A palmitate level similar to the HF group. However, addition of the $100 \mathrm{mg} \mathrm{OPH} / \mathrm{g}$ of HF food decreased the Vitamin A palmitate level to $31.78 \mu \mathrm{g} / \mathrm{g}$ of tissue. Vitamin A palmitate level in animals on ND, was slightly lowered than HF groups, but this decrease was not significantly different (figure 43). 


\begin{tabular}{|l|l|l|l|l|l|}
\hline \multicolumn{2}{|l|}{ Group } & $\begin{array}{l}\text { Vitamin E } \boldsymbol{\mu g} / \mathbf{g} \text { of } \\
\text { tissue }\end{array}$ & $\begin{array}{l}\text { Vitamin A } \boldsymbol{\mu g} / \mathbf{g} \\
\text { of tissue }\end{array}$ & $\begin{array}{l}\text { Retinol } \\
\text { equivalent } \\
\boldsymbol{\mu g} / \mathbf{g} \text { of tissue }\end{array}$ & $\begin{array}{l}\text { Vitamin C } \boldsymbol{\mu g} / \mathbf{g} \\
\text { of tissue }\end{array}$ \\
\hline 1 & High fat diet & $13.05 \pm 2.18 \mathrm{a}$ & $21.82 \pm 21.82 \mathrm{a}$ & $52.96 \pm 8.28 \mathrm{a}$ & $850.65 \pm 53.16 \mathrm{a}$ \\
\hline 2 & $\begin{array}{l}\text { High fat diet }+ \\
1 \mathrm{mg} / \mathrm{g} \text { food }\end{array}$ & $27.62 \pm 10.72 \mathrm{a}$ & $20.35 \pm 3.46 \mathrm{a}$ & $33.42 \pm 5.46 \mathrm{a}$ & $774.49 \pm 44.01 \mathrm{a}$ \\
\hline 3 & $\begin{array}{l}\text { High fat diet }+ \\
10 \mathrm{mg} / \mathrm{g} \text { food }\end{array}$ & $11.84 \pm 2.19 \mathrm{a}$ & $28.09 \pm 4.02 \mathrm{a}$ & $50.17 \pm 7.74 \mathrm{a}$ & $841.92 \pm 54.08 \mathrm{a}$ \\
\hline 4 & $\begin{array}{l}\text { High fat diet }+ \\
100 \mathrm{mg} / \mathrm{g} \text { food }\end{array}$ & $14.83 \pm 4.46 \mathrm{a}$ & $22.12 \pm 2.40 \mathrm{a}$ & $39.46 \pm 5.50 \mathrm{a}$ & $812.34 \pm 33.58 \mathrm{a}$ \\
\hline 5 & Normal diet & $10.26 \pm 1.35 \mathrm{a}$ & $30.34 \pm 5.26 \mathrm{a}$ & $62.96 \pm 10.94 \mathrm{a}$ & $779.49 \pm 33.78 \mathrm{a}$ \\
\hline
\end{tabular}

Table 11: Vitamin A palmitate, Retinol equivalent, vitamins $\mathrm{E}$, and $\mathrm{C} \mu \mathrm{g} / \mathrm{g}$ of tissue, in lung tissue of CD-1 mice. Statistical differences were evaluated by one-way ANOVA using SPSS 11.0 for windows 7 (SPSS Inc., Chicago). Values with $\mathrm{P}<0.05$ were considered significantly different between the groups using the LSD test (mean \pm standard error). 


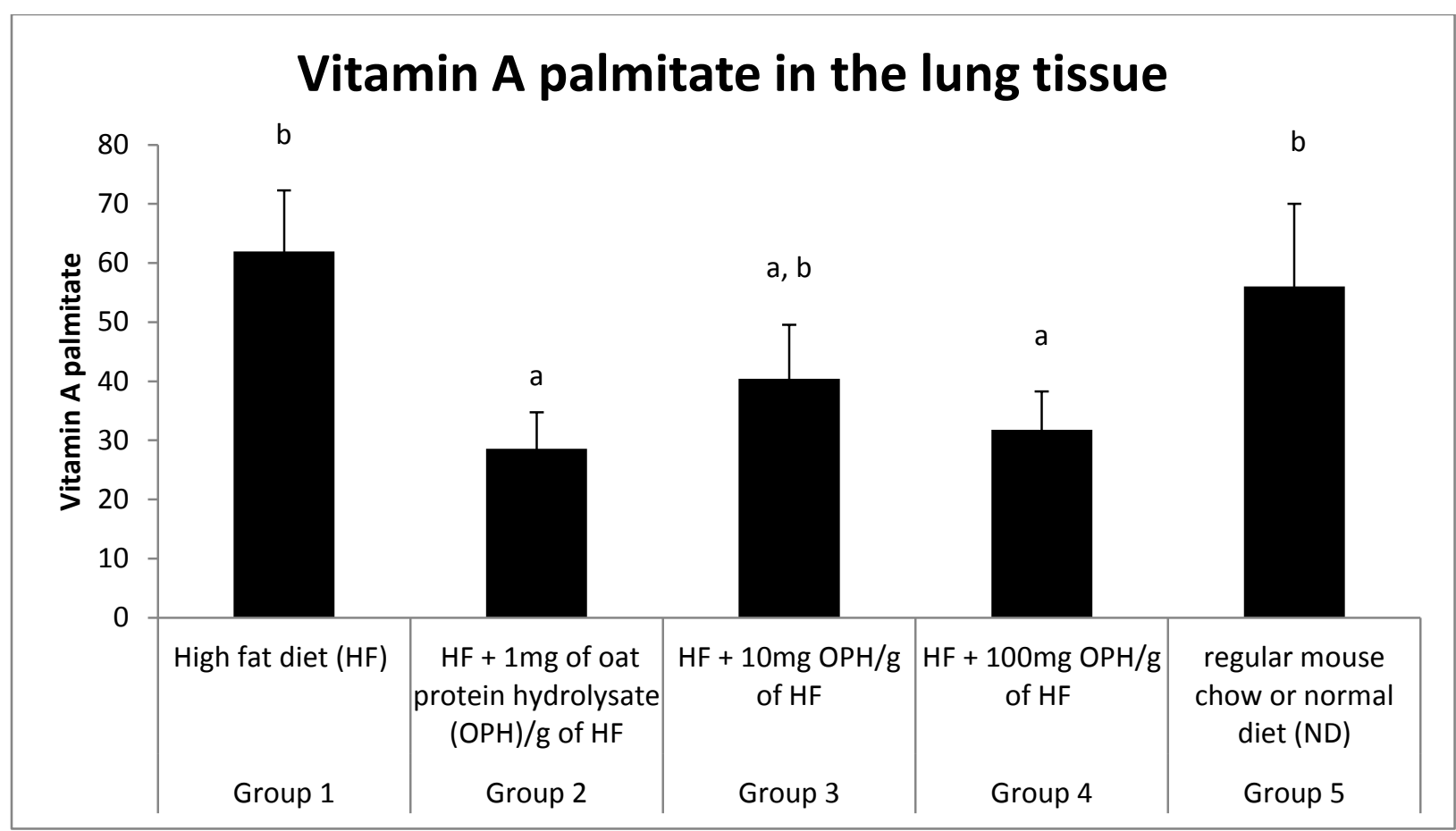

Figure 45: Vitamin A palmitate level in the lung tissue of CD-1 mice. Statistical differences were evaluated by one-way ANOVA using SPSS 11.0 for windows 7 (SPSS Inc., Chicago). Values with $\mathrm{P}<0.05$ were considered significantly different between the groups using the LSD test (mean \pm standard error).

\subsection{Further discussion of the effect of OPH supplementations}

OPH was added to the HF diet of CD-1 mice in three different concentrations. The advantage of addition of hydrolyzed protein versus addition of non-hydrolyzed protein, was that hydrolyzed proteins or $\mathrm{OPH}$ had higher antioxidant activity relative to non-hydrolyzed proteins, as it was discussed in chapter 3. Concentrations of OPH used are within the range of those in other studies where animals were fed high fat diets (Nadeem et al. 2012; Décordé et al. 2010; Khalid and Siddiqui 2012; Li et al. 2011a). Hydrolyzed proteins consumed can be absorbed more quickly 
and exert better biological function that intact proteins which must first be cleaved by digestive proteases. The HF diet used in this study contained $23.5 \%$ proteins and adding $100 \mathrm{mg} \mathrm{OPH} / \mathrm{g}$ of $\mathrm{OPH}$ brings the proteins content to $25.9 \%$. This is still in the range of $10-30 \%$ proteins recommended by health Canada (Trumbo et al. 2002). Proteins and their hydrolysates are used in nutritional products like granola bars and in beverages. Some granola bars contain $11 \mathrm{~g}$ of proteins.

OPH that prevented the formation of lipid peroxides and scavenged radicals in the in-vitro experiments was added to CD-1 mice fed high fat diet. OPH supplementation had no effect on bodyweight despite the fact that the higher level provided additional 10\% energy in the form of proteins. Most rodents generally tend to become obese on high-fat diets; however, the response to weight gain can vary. Mice strains such as $\mathrm{C} 57 \mathrm{Bl6}$ or AKR are more susceptible to obesity when fed high-fat diets compared to CD-1 mice(Rossmeisl et al. 2003). If the study was conducted for, more than three weeks may be differences would have been observed in weight after supplementation with OPH. Contrary to weight, addition of OPH to HF diet did increase the respiratory exchange ratio (RER). The increase was not due to an increase in mobility as there was not a change in locomotor activity, but can be attributed to the fact that mice on OPH used more carbohydrates or the extra protein from OPH to produce energy although protein oxidation is generally considered negligible.

The majority of oxidative stress markers were measured mainly in blood and liver but a few were quantified in brain and heart samples. In red blood cells, it was found that, $100 \mathrm{mg} \mathrm{OPH} / \mathrm{g}$ increased the total antioxidant capacity (ORAC) and the activity of SOD enzyme. Superoxide 
$\left(\mathrm{O}_{2}{ }^{-}\right)$which is very reactive is converted by SOD to lesser reactive $\mathrm{H}_{2} \mathrm{O}_{2}$ which can then be converted into water. The amount of $\mathrm{H}_{2} \mathrm{O}_{2}$ in plasma was higher $(\mathrm{p}<0.05)$ but surprisingly the activity of CAT that can catalyze its conversion to water was lower. Glutathione peroxide (GPx), another enzyme that can detoxify $\mathrm{H}_{2} \mathrm{O}_{2}$ was not determined in this study; however, the elevated amount of thiol group found in blood may be useful for the detoxification of $\mathrm{H}_{2} \mathrm{O}_{2}$ and for the increase of total antioxidant capacity. The higher concentration of $\mathrm{H}_{2} \mathrm{O}_{2}$ did not lead to protein oxidation as the concentration of advanced oxidation products of proteins was reduced in mice that received $100 \mathrm{mg} \mathrm{OPH} / \mathrm{g}$.

The vast majority of oxidative markers were measure in liver because as a main detoxifying organ, it could be prone to oxidative damage. No OPH concentration tested affected total antioxidant capacity, hydrogen peroxides, protein oxidation products, nitric oxide, vitamins A or E levels. The only notable change was in the vitamin C. All three concentrations of OPH added to the HF diet increased liver vitamin $\mathrm{C}(\mathrm{p}<0.05)$ content in a non-dose dependent manner. Vitamin $\mathrm{C}$ had other functions, apart from preventing oxidative damage. It is for example important for growth synthesis of collagen, a protein used in skin, cartilage, tendons, ligaments, and blood vessels (Boyera et al. 1998). It is also involved in the hydroxylation of proline residues in different proteins (Brody 1999). Absorbed peptides from OPH and the extra amino acids provided may have contributed to the increase of vitamin $\mathrm{C}$. 


\section{Chapter 6}

\section{Conclusion and Future work}




\section{Conclusion}

$\mathrm{APH}, \mathrm{TPH}$, and their ultra-filtered fraction were shown to have different ferrous ion-chelating and radical scavenging activities. The highest radical scavenging activity on DPPH was demonstrated by APH $2 \mathrm{kDa}$, at 15,45 , and $30 \mathrm{~min}$. Better ferrous ion-chelating properties were demonstrated by the $200 \mathrm{~g} / \mathrm{mL}$ TPH, $43.8 \%$ compared to APH which had a $31.8 \%$ of ferrous ionchelating properties. Linoleic acid autoxidation formation was equally inhibited by both TPH and APH. From this finding, it can be concluded that by enzymatic digestion of oat flour, peptides that have radical scavenging properties can be produced, and it can be used in food products to prevent oxidative rancidity, as well as increasing the nutritional values. Therefore the investigation of the structure, activity, and their mechanistic would be beneficial to study.

Results from the extraction of protein using different cell wall carbohydrase degrading enzyme with different concentrations, showed increase protein content except the samples treated with celluclast. The ORAC or the peroxyl radical scavenging activity was significantly higher for at least one concentration of the enzymes compared to the sample that were not treated with enzyme (Control). The sample that was treated with viscozyme fallowed by Alcalase, had both higher peroxyl radical scavenging as well as hydroxyl radical scavenging activity. Mass spectrometry helped us to identify four different novel peptides from the control and the sample that was treated with viscozyme. From all these results in this study, it can be concluded that both enzymes viscozyme and amyloglucosidase, can be used in the preparation of protein isolates and hydrolysates with improved antioxidative properties. The biological activities such as anti-oxidant, and anti-inflammatory properties of these isolated peptides should be evaluated in the future studies, as well as fractionation of the viscozyme pretreated digests and the control can be helpful in identifying the peptides with potential biological functions. 
In this study, results from mice consumed $\mathrm{HF}$ diet in combination of $\mathrm{OPH}$, showed that the radical scavenging activity in $\mathrm{RBC}$ increased due to synthesis of thiol containing peptides. Also SOD activity has shown to be increased in RBC as well as slight increase in CAT and SOD activity in the liver has been observed. Since there was opposing results regarding concentration of OPH for example 1 and $100 \mathrm{mg} / \mathrm{OPH} / \mathrm{g}$ compared to $10 \mathrm{mg} \mathrm{OPH} / \mathrm{g}$, further study is needed to find the optimum concentration.

AOPP level, was lowered significantly after addition of OPH to the HF diet in the brain and the heart tissues, NO level was significantly lowered in the brain tissue after addition of the $\mathrm{OPH}$, and vitamin $\mathrm{C}$ level was increased significantly after addition of the $\mathrm{OPH}$.

\section{Future work}

In this study, the antioxidant capacity of the oat proteins digested with alcalase as well as trypsin was examined. Hydrolysates with proteins were the most active and then subsequently tested in vivo in CD-1 mice fed high fat diets. There are to be no dose dependent and also some contradictory data between the three concentration tested and this could be because of the short duration of the study. Futures studies can therefore:

1) Be performed for 6 weeks instead of 3 weeks (animal will gain more weight) and measure liver weight, enzymes involved in lipid metabolism in addition to antioxidant enzymes

2) Use other models like AKR can be used because of their ability to gain weight more rapidly

3) Determine the sequence of all peptides present in OPH and well as its free amino acid content. In chapter 4, different carbohydrases were used to break down cell wall polysaccharides and increase protein extraction and antioxidant activities of proteins hydrolyzed with alcalase. Tandem mass spectrometry was used to identify the sequence of peptides. Preliminary data allow 
the identification of 4 peptides from analysis of double charged peaks only. Future investigation can

a) Tested the antioxidant activity of the four identified peptides and determine their contribution to the activity of the hydrolysates

b) Investigate the bioavailability of the four peptides and their ability to prevent oxidative stress in cultured intestinal cells

c) Identify peptides in other samples including those that are single charged 
Chapter 7 


\section{References}

Aebi H,. 1984. Catalase in vitro. Methods Enzymol 105: 121-126.

Ajibola, C.,F., Fashakin, J.,B., Fagbemi, T.,N., and Aluko, R.,E. 2011. Effect of Peptide Size on Antioxidant Properties of African Yam Bean Seed (Sphenostylis stenocarpa) Protein Hydrolysate Fractions. Int J Mol Sci 12(10): 6685-6702.

Aluko, R.,E. 2012. Functional Foods and Nutraceuticals. Springer Science, New York.

Aluko, R.,E. and McIntosh, T. 2001. Polypeptide profile and functional properties of defatted meals and protein isolates of canola seeds. J Sci Food Agric 81(4): 391-396.

Aluko, R.,E., McIntosh, T., and Katepa-Mupondwa, F. 2005. Comparative study of the polypeptide profiles and functional properties of Sinapis alba and Brassica juncea seed meals and protein. J Sci Food Agric 85(11): 1931-1937.

Anderson, J., W. and Gustafson N, J. 1988. Hypocholesterolemic effects of oat and bean products. Am J Clin Nutr 48: 749-753.

Andersson, K.,E. and Hellstrand, P. 2012. Dietary oats and modulation of atherogenic pathways. Mol Nutr Food Res 56(7): 1003-1013.

Ando, K. and Fujita, T. 2009. Metabolic syndrome and oxidative stress. Free Radical Biol. Med 47: 213-218.

Ansharullah, J., Hourigar, A., and Chesterman, C.F. 1997. Application of carbohydrases in extracting protein from rice bran. J Sci Food Agric. 74: 141-146. 
Aoyama, T., Fukui, K., Nakamori, T., Hashimoto, Y., Yamamoto, T., Takamatsu, K., and Sugano, M. 2000a. Effect of soy and milk whey protein isolates and their hydrolysates on weight reduction in genetically obese mice. Biosci Biotechnol Biochem 64(12): 2594-2600.

Aoyama, T., Fukui, K., Takamatsu, K., Hashimoto, Y., and Yamamoto, T. 2000b. Soy protein isolate and its hydrolysate reduce body fat of dietary obese rats and genetically obese mice (yellow KK). Nutrition 16(5): 349-354.

Arcan, I. and Yemenicioğlu, A. 2007. Antioxidant activity of protein extracts from heattreated or thermally processed chickpeas and white beans. Food Chem. 103(2): 301312.

Arendt, E.,K. and Zannini, E. 2013a. 7 - Oats. In Cereal Grains for the Food and Beverage Industries. Edited by E.K. Arendt and E. Zannini. Woodhead Publishing. pp. 243-283e.

Arendt, E.K. and Zannini, E. 2013b. 1 - Wheat and other Triticum grains. In Cereal Grains for the Food and Beverage Industries. Edited by E.K. Arendt and E. Zannini. Woodhead Publishing. pp. 1-67e.

Avinash, S., Anitha, M., Chandran, V., Rao, G., Sudha, K., and Shetty, B. 2009. Advanced oxidation protein products and total antioxidant activity in colorectal carcinoma. Indian J Physiol Pharmacol 53(4): 370-374. 
Babusikova, E., Evinova, A., Hatok, J., Dobrota, D., and Jurecekova, J. 2013. Oxidative Changes and Possible Effects of Polymorphism of Antioxidant Enzymes in Neurodegenerative Disease.In Chapter 18. In Edited by K. Uday. . pp. 421-455.

Bader, S., Oviedo, J., P., Pickardt, C., and Eisner, P. 2011. Influence of different organic solvents on the functional and sensory properties of lupin (Lupinus angustifolius L.) proteins. LWT - Food Science and Technology 44(6): 1396-1404.

Banerjee, D., Kumar, A.P., Kumar, B., Madhusoodanan, U.K., Nayak, S., and Jacob, J. 2002. Determination of absolute hydrogen peroxide concentration by spectrophotometric method. Current Science 83: 1193-1194.

Banerjee, D., Madhusoodanan, U.,K., Nayak, S., and Jacob, J. 2003. Urinary hydrogen peroxide: a probable marker of oxidative stress in malignancy. Clin Chim Acta 334: 205-209.

Barbin, D.,F., Natsch, A., and Müller, R.,K. 2011. Improvement of functional properties of rapeseed protein concentrates produced via alcoholic processes by thermal and mechanical treatments. J FoodProcess Preserve 35: 369-375.

Behall, K.,M., Scholfield, D.,J., Hallfrisch, J.,G., and Liljeberg-Elmståhl, H.,G. 2006. Consumption of both resistant starch and beta-glucan improves postprandial plasma glucose and insulin in women. Diabetes Care 29(5): 976-981.

Berlett, B.,S. and Stadtman, E.,R. 1997. Protein Oxidation in Aging, Disease, and Oxidative Stress. Journal of Biological Chemistry 272: 20313-20316. 
Bernhard, S., A. 1968. The structure and function of enzymes. Benjamin, New York.

Boye, J.,I., Aksay, S., Roufik, S., Ribéreau, S., Mondor, M., Farnworth, E., and Rajamohamed, S.,H. 2010. Comparison of the functional properties of pea, chickpea and lentil protein concentrates processed using ultra filtration and isoelectric precipitation techniques. Food Res Int 43: 537-546.

Boyera, N., Galey, I., and Bernard, B.,A. 1998. Effect of vitamin C and its derivatives on collagen synthesis and cross-linking by normal human fibroblasts. Int J Cosmet Sci 20(3): 151-158.

Bratt, K., Sunnerheim, K., Bryngelsson, S., Fagerlund, A., Engman, L., Andersson, R.,E., and Dimberg, L.,H. 2003. Avenanthramides in oats (Avena sativa L.) and structureantioxidant activity relationships. J Agric Food Chem 51(3): 594-600.

Brindzová, L., Čertík, M., Rapta, P., Zalibera, M., Mikulajová, A., and Takácsová, M. 2008. Antioxidant activity, $\beta$-glucan and lipid contents of oat varieties. J. Food Sci 26(3): 163-173.

Brody, T. 1999. 9 - Vitamins. In Nutritional Biochemistry (Second Edition). Edited by T. Brody. Academic Press, San Diego. pp. 491-692.

Bueno-Solano, C., López-Cervantes, J., Campas-Baypoli, O.N., Lauterio-García, R., Adan-Bante, N.,P., and Sánchez-Machado, D.,I. 2009. Chemical and biological characteristics of protein hydrolysates from fermented shrimp by-products. Food Chem. 112: 671-675. 
Burris, R.,L., Xie, C.,H., Thampi, P., Wu, X., Melnyk, S.,B., and Nagarajan, S. 2010. Dietary rice protein isolate attenuates atherosclerosis in apoE-deficient mice by upregulating antioxidant enzymes. Atherosclerosis 212(1): 107-115.

Byrne, E. 2002. Does mitochondrial respiratory chain dysfunction have a role in common neurodegenerative disorders? J Clin Neurosci 9(5): 497-501.

Cai, J., Yang, L., He, H.,J., Xu, T., Liu, H.,B., Wu, Q., Ma, Y., Liu, Q.,H., and Nie, M.,H. 2014. Antioxidant capacity responsible for a hypocholesterolemia is independent of dietary cholesterol in adult rats fed rice protein. Gene 533(1): 57-66.

Chen, C.,Y., Milbury, P.,E, Collins, F.,W., and Blumberg, J.,B. 2007. Avenanthramides are bioavailable and haveantioxidant activity in humans after acute consumption of an enriched mixture from oats. J Nutr 137(6): 1375-1382.

Chen, C.,Y., Milbury, P.,E., Kwak, H.,K., Collins, F.,W., Samuel, P., and Blumberg, J.,B. 2004. Avenanthramides and phenolic acids from oats are bioavailable and act synergistically with vitamin $\mathrm{C}$ to enhance hamster and human LDL resistance to oxidation. J Nutr 134(6): 1459-1466.

Chen, H.,M., Muramoto, K., Yamauchi, F., and Nokihara, K. 1996. antioxidant activity of digested peptides based on the antioxidative peptide isolated from digested of a soybean protein. J A gric Food Chem 44: 2619-2623.

Chen, H.M., Muramoto, K., and Yamauchi, F. 1995. Structural analysis of antioxidativepeptides from soybean $\beta$-conglycinin. J Agric Food Chem 43: 574-578. 
Chen, H.,M., Muramoto, K., Yamauchi, F., Fujimoto, K., and Nokihara, K. 1998. Antioxidative Properties of Histidine-Containing Peptides Designed from Peptide Fragments Found in the Digests of a Soybean Protein. J Agric Food Chem 46(1): 4953.

Cheng, T., Zhu, Z., Masuda, S., and Morcos, N. 2001. Effects of multinutrient supplementation on antioxidant defense systems in healthy human beings. Journal of Nutritional Biochemistry 12(7): 388-395.

Cheng, Y.,H., Wang, Z., and Xu, S.,Y. 2006. Antioxidant properties of wheat germ protein hydrolysates evaluated in vitro. J Cent S Univ 13(2): 160-165.

Cheng, Y., Zhang, L., Sun, W., Tang, J., Lv, Z., Xu, Z., and Yu, H. 2014. Protective effects of a wheat germ peptide (RVF) against $\mathrm{H} 2 \mathrm{O}$ 2-induced oxidative stress in human neuroblastoma cells. Biotechnol Lett 36: 1615-1622.

Cheng, Z., Zhang, J., Ballou, D.,P., and Williams, C.,H. 2011. On the reactivity of thioredoxin as a protein thiol-disulfide oxidoreductase. Chem Rev 111(9): 5768-5783.

Cheung, I.,W., Nakayama, S., Hsu, M.,N., Samaranayaka, A.,G., and Li-Chan, E.,C. 2009. Angiotensin-I converting enzyme inhibitory activity of hydrolysates from oat (Avena sativa) proteins by in silico and in vitro analyses. J Agric Food Chem 57(19): 9234-9242. 
Cirulli, C., Chiappetta, G., Marino, G., Mauri, P., and Amoresano, A. 2008. Identification of free phosphopeptides in different biological fluids by a mass spectrometry approach. ABC 392(1-2): 147-159.

Cluskey, J.E., Wu, Y.V., Wall, J.S., and Inglett, G.E. 1973. Oat protein concentrates from a wet-milling process: preparation. Cereal Chem 50: 475-480.

Cohen, L.,A. 1999. Dietary fiber and breast cancer. Anticancer Res 19(5A): 3685-3688.

Davalos, A., Miguel, M., Bartolome, B., and Lopez-Fandino, R. 2004. Antioxidant activity of peptides derived from egg white proteins by enzymatic hydrolysis. J Food Protect 67(9): 1939-1944.

Dávalos, A., Miguel, M., Bartolomé, B., and López-Fandiño, R. 2004. Antioxidant activity of peptides derived from egg white proteins by enzymatic hydrolysis. J Food Prot 67(9): 1939-1944.

David M. Peterson. 2001. Oat Antioxidants. Journal of Cereal Science 33: 115-129.

Davis, J., Dean, L., Price, K., and Sanders, T. 2010. Roast effects on the hydrophilic and lipophilic antioxidant capacities of peanut flours, blanched peanut seed and peanut skins. Food Chemistry 119: 539-547.

de Melo C, L., Queiroz, M.,G., Fonseca, S.,G., Bizerra, A.,M., Lemos, T.,L., Melo, T.,S., Santos, F.,A., and Rao, V.,S. 2010. Oleanolic acid, a natural triterpenoid improves blood glucose tolerance in normal mice and ameliorates visceral obesity in mice fed a high-fat diet. Chem Biol 185(1): 59-65. 
Décordé K, A.,A., Lacan, D., Ramos, J., Fouret, G., Ventura, E., Feillet-Coudray, C., Cristol, J.,P., and Rouanet, J.,M. 2009. Preventive effect of a melon extract rich in superoxide scavenging activity on abdominal and liver fat and adipokine imbalance in high-fat-fed hamsters. J Agric Food Chem 57(14): 6461-6467.

Décordé, K., Ventura, E., Lacan, D., Ramos, J., Cristol, J.,P., and Rouanet, J.,M. 2010. An SOD rich melon extract Extramel prevents aortic lipids and liver steatosis in dietinduced model of atherosclerosis. Nutr Metab Cardiovasc Dis 20(5): 301-307.

Del Guerra, S., D’Aleo, V., Lupi, R., Masini, M., Bugliani, M., Boggi, U., Filipponi, F., and Marchetti, P. 2009. Effects of exposure of human islet beta-cells to normal and high glucose levels with or without gliclazide or glibenclamide . Diabetes Metab 35(4): 293-298.

Delmas-Beauvieux, M., Combe, C., Peuchant, E., Carbonneau, M., Dubourg, L., de Précigout, V., Aparicio, M., and Clerc, M. 1995. Evaluation of red blood cell lipoperoxidation in hemodialysed patients during erythropoietin therapy supplemented or not with iron. Nephron 69: 404-410.

Demori, L., Voci, A., Fugassa, E., and Burlando, B. 2006. Combined effects of high-fat diet and ethanol induce oxidative stress in rat liver. Alcohol 40(3): 185-191.

Dinis,T,C,P., Madeira,V,M,C., and Almeida, L.,M. 1994. Action of Phenolic Derivatives (Acetaminophen, Salicylate, and 5-Aminosalicylate) as Inhibitors of Membrane Lipid Peroxidation and as Peroxyl Radical Scavengers. Arch. Biochem. Biophys. 315(1): $161-169$. 
Dobrian, A., Davies, M., Schriver, S., Lauterio, T., and Prewitt, R. 2001. Oxidative stress in a rat model of obesity-induced hypertension. Hypertension 37(2): 554-560.

Drogaris, P., Le, Blanc, J,C,Y., Fitzgerald, J.E., Lowndes, N.F., Verreault, A., and Thibault, P. 2009. Enhanced protein detection using a trapping mode on a hybrid quadrupole linear ion trap (Q-Trap). Anal Chem 81(15): 6300-6309.

Du, H., van der, A, D,L., Boshuizen, H.,C., Forouhi, N.,G., Wareham, N.,J., Halkjaer, J., Tjønneland, A., Overvad, K., Jakobsen, M.,U., Boeing, H., Buijsse, B., Masala, G., Palli, D., Sørensen, T.,I., Saris, W.,H., and Feskens, E.,J. 2010. Dietary fiber and subsequent changes in body weight and waist circumference in European men and women. Am J Clin Nutr 91(2): 32-336.

Ellman, G.L. 1959. Tissue sulfhydryl groups. Arch. Biochem. Biophys. 82(1): 70-77.

Erukainure, O.,L., Ebuehi,O,A,T., Adeboyejo, F.,O., Okafor, N.,E., Muhammad, A., and Elemo, G.,N. 2013. Fiber-enriched biscuit enhances insulin secretion, modulates $\beta$ cell function, improves insulin sensitivity, and attenuates hyperlipidemia in diabetic rats. PharmaNutrition 1(2): 58-64.

FAO/WHO/UNU. 2007. protein and amino acid requirement in human nutrition report of a joint $\mathrm{FAO} / \mathrm{WHO}$ ?UNU expert consultation, WHO technical report series 935. Geneva WHo. .

Fardet, A., Rock, E., and Rémésy, C. 2008. Is the in vitro antioxidant potential of wholegrain cereals and cereal products well reflected in vivo? J. Cereal Sci. 48(2): 258-276. 
Feillet-Coudray, C., Sutra, T., Fouret, G., Ramos, J., Wrutniak-Cabello, C., Cabello, G., Cristol, J.P., and Coudray, C. 2009. Oxidative stress in rats fed a high-fat highsucrose diet and preventive effect of polyphenols: Involvement of mitochondrial and NAD(P)H oxidase systems. Free Radical Biology and Medicine 46(5): 624-632.

Feillet-Coudraya, C., Sutrab, T., Foureta, G., Ramos, J., Wrutniak-Cabello, C., Cabello, G., Cristol, J., and Coudray, C. 2009. Oxidative stress in rats fed a high-fat highsucrose diet and preventive effect of polyphenols: Involvement of mitochondrial and NAD(P)H oxidase systems. Free Radic. Biol. Med 46: 624-632.

Ferrali, M., Signorini, C., Caciotti, B., Sugherini, L., Ciccoli, L., Giachetti, D., and Comporti, M. 1997. Protection against oxidative damage of erythrocyte membrane by the flavonoid quercetin and its relation to iron chelating activity. FEBS Lett 416(2): 123-129.

Furukawa, S., Fujita, T., Shimabukuro, M., Iwaki, M., Yamada, Y., Nakajima, Y., Nakayama, O., Makishima, M., Matsuda, M., and Shimomura, I. 2004. Increased oxidative stress in obesity and its impact on metabolic syndrome. J. Clin. Invest. 114(12): 1752-1761.

Furuya, R., Kumagai, H., Odamaki, M., Takahashi, M., Miyaki, A., and Hishida, A. 2009. Impact of residual renal function on plasma levels of advanced oxidation protein products and pentosidine in peritoneal dialysis patients. Nephron Clin Pract 112(4): 255-261. 
Ghaly, A.,E. and Alkoaik, F.,N. 2010. Extraction of protein from common plant leaves for use as human food. Am J Appl Sci 7: 323-334.

Ghodsvali, A., Khodaparast, M,H,H., Vosoughi, M., and Diosady, L.,L. 2005. Preparation of canola protein materials using membrane technology and evaluation of meals functional properties. Food Res Int 38(2): 223-231.

Grossman, M.V., Rao, C.S., and Da Silva, R. 1980. Extraction of proteins from buckwheat bran. J Food Biochem. 4(3): 181-188.

Grune, T., Catalgol, B., and Jung, T. 2013. Protein oxidation and aging. John Wiley \& Sons, Inc, Canada.

Gu, Y., Majumder, K., and Wu, J. 2011. QSAR-aided in silico approach in evaluation of food proteins as precursors of ACE inhibitory peptides. Food Research International 44(8): 2465-2474.

Guan, X. and Yao, H. 2008. Optimization of Viscozyme L-assisted extraction of oat bran protein using response surface methodology. Food Chem. 106(1): 345-351.

Guan, X., Yao, H., Chen, Z., Shan, L., and Zhang, M. 2007. Some functional properties of oat bran protein concentrate modified by trypsin. Food Chem. 101(1): 163-170.

Gülçin, I. 2007. Comparison of in vitro antioxidant and antiradical activities of 1-tyrosine and 1-dopa. Amino Acids 32(3): 431-438. 
Guo, H., Sun, J., He, H., Yu, G.,C., and Du, J. 2009. Antihepatotoxic effect of corn peptides against Bacillus Calmette-Guerin/lipopolysaccharide-induced liver injury in mice. Food Chem Toxicol 47(10): 2431-2435.

Guo, W., Wise, M.,L., Collins, F.,W., and Meydani, M. 2008. Avenanthramides, polyphenols from oats, inhibit IL-1beta-induced NF-kappaB activation in endothelial cells. Free Radic Biol Med 44: 415-429.

Halliwell, B.G.J. 1989. Free Radicals in Biology and Medicine. Clarendon, Oxford .

Harris, P.J. and Ferguson, L.R. 2014. Chapter 16 - Wheat and Rice Dietary Fiber in Colorectal Cancer Prevention and the Maintenance of Health. In Wheat and Rice in Disease Prevention and Health. Edited by R.R.W.R.P. Zibadi. Academic Press, San Diego. pp. 201-210.

Hartwell, G.A. 1926. The dietetic value of oatmeal proteins. Biochem J 20: 751-758.

Hazel, H., Szeto. 2006. Cell-permeable, Mitochondrial-targeted, Peptide Antioxidants. AAPS J 8(2): 277-283.

Heaton, K.,W., Marcus, S.,N., Emmett, P.,M., and Bolton, C.,H. 1988. Particle size of wheat, maize, and oat test meals: effects on plasma glucose and insulin responses and on the rate of starch digestion in vitro. Am J Clin Nutr 47(4): 675-682.

Hodgson, E., K. and Fridovich, I. 1975. The interaction of bovine erythrocyte superoxide dismutase with hydrogen peroxide: chemiluminescence and peroxidation. Biochemistry 14: 5299-5303. 
Hsu, C. and Yen, G. 2007. Effect of gallic acid on high fat diet-induced dyslipidaemia, hepatosteatosis and oxidative stress in rats. Br. J. Nutr. 98(4): 727-735.

Indel, P., Turner, R.,E., and Ross, D. 2010. Discovering Nutrition. Jones and Bartlett, Sudbury, Massachuetts.

Irshad, I., Kanekanian, A., Peters, A., and Masud, T. 2015. Antioxidant activity of bioactive peptides derived from bovine casein hydrolysate fractions. J Food Sci Technol 52(1): 231-239.

Je, J.Y., Park, P.,J., and Kim, S.,K. 2005. Antioxidant activity of a peptide isolated from alaska pollack (theragra chalcogramma) frame protein hydrolysate. Food Res Int 38(1): 45-50.

Je, J.Y., Park, P.,J., Kwon, J.,Y., and Kim, S.,K. 2004. A novel angiotensin I converting enzyme inhibitory peptide from alaska pollack (theragra chalcogramma) frame protein hydrolysate. J Agric Food Chem 52(26): 7842-7845.

Jenkins, D.,J., Wolever, T.,M., Taylor, R.,H., Barker, H., Fielden, H., Baldwin, J.,M., Bowling, A.,C., Newman, H.,C., Jenkins, A.,L., and Goff, D.,V. 1981. Glycemic index of foods: a physiological basis for carbohydrate exchange. Am J Clin Nutr 34(3): 362-6.

Jodayree, S., Smith, J.C., and Tsopmo, A. 2012. Use of carbohydrase to enhance protein extraction efficiency and antioxidative properties of oat bran protein hydrolysates. Food Res. Int. 46(1): 69-75. 
Jones, D.B., Caldwell, A., and Widness, K.D. 1948. Comparative growth-promoting values of the proteins of cereal grains. J. Nutr 35: 639-649.

Jung, E.,Y., Lee, H.,S., Lee, H.,J., Kim, J.,M., Lee, K.,W., and Suh, H.,J. 2010. Feeding silk protein hydrolysates to $\mathrm{C} 57 \mathrm{BL} / \mathrm{KsJ}-\mathrm{db} / \mathrm{db}$ mice improves blood glucose and lipid profiles. Nutr Res 30(11): 783-790.

Karaca, A.,C., Low, N., and Nickerson, M. 2011. Emulsifying properties of chickpea, faba bean, lentil and pea proteins produced by isoelectric precipitation and salt extraction. Food Res Int 44: 2742-2750.

Khalid, M. and Siddiqui, H.,H. 2012. Evaluation of weight reduction and anti-cholesterol activity of Punarnava root extract against high fat diets induced obesity in experimental rodent. APJTB 2(3): 1323-1328.

Kikuzaki, H., Hisamoto, M., Hirose, K., Akiyama, K., and Taniguchi, H. 2002. Antioxidant properties of ferulic acid and its related compounds. J Agric Food Chem. 50(7): 2161-2168.

Klockeman, D.,M., Toledo, R., and Sims, K.,A. 1997. Isolation and characterization of defatted canola meal protein. J Agric Food Chem 45(10): 3867-3870.

Lazaridou, A. and Biliaderis, C.G. 2007. Molecular aspects of cereal $\beta$-glucan functionality: Physical properties, technological applications and physiological effects. J. Cereal Sci. 46(2): 101-118. 
Lee, J., Koo, N., and Min, D.B. 2004. Reactive oxygen species, aging, and antioxidative nutraceuticals. Compr Rev Food Sci F 3: 21-33.

Lestari, D., Mulderb, W., and Sandersa, J. 2010. Improving Jatropha curcas seed protein recovery by using counter current multistage extraction. Biochem Eng J 50: 16-23.

Li, H., Prairie, N., Udenigwe, C.,C., Adebiyi, A.,P., Tappia, P.,S., Aukema, H.,M., Jones, P.,J., and Aluko, R.,E. 2011a. Blood pressure lowering effect of a pea protein hydrolysate in hypertensive rats and humans. J Agric Food Chem 59(18): 9854-9860.

Li, Y., Jiang, B., Zhang, T., Mu, W., and Liu, J. 2008. Antioxidant and free radicalscavenging activities of chickpea protein hydrolysate (CPH). Food Chem. 106(2): $444-450$.

Liu, L., Zubik, L., Collins, F.,W., Marko, M., and Meydani, M. 2004. The antiatherogenic potential of oat phenolic compounds. Atherosclerosis 175(1): 39-49.

Liu, S., Willett, W.,C., Manson, J.,E., Hu, F.,B., Rosner, B., and Colditz, G. 2003. Relation between changes in intakes of dietary fiber and grain products and changes in weight and development of obesity among middle-aged women. Am J Clin Nutr 78(5): 920-927.

Liyana-Pathirana, C.,M. and Shahidi, F. 2006. Importance of insoluble-bound phenolics to antioxidant properties of wheat. J Agric Food Chem. 54: 1256-1264. 
Lushchak, V. and Bagnyukova, T. 2006. Heat shock affects free radical processes in goldfish tissues. I. Oxidative stress markers. Comp Biochem Physiol A Mol Integr Physiol. 143: 30-35.

Ma, C.,Y. 1985. Functional Properties of Oat Concentrate Treated with Linoleate or Trypsin. Can Inst Food Sci Technol J 18(1): 79-84.

Malgorzata, I., Grazyna, C., Elzbieta, L., Edward, B., and Lidia, W. 2004. Plasma levels of total, free and protein bound thiols as wellas sulfane sulfur in different age groups of rats. Acta Biochemica Polonica 51(3): 815-824.

Markwell, M., Haas, S., Bieber, L., and Tolbert, N. 1978. A modification of the Lowry procedure to simplify protein determination in membrane and lipoprotein samples. Anal Biochem. 87(1): 206-210.

Marques, M.,R., Soares, Freitas, R,A., Corrêa, Carlos, A,C., Siguemoto, É,S,2., Fontanari, G,G,., and Arêas, J.,A. 2015. Peptides from cowpea present antioxidant activity, inhibit cholesterol synthesis and its solubilisation into micelles. Food Chem 168(1): 288-293.

Marsche, G., Frank, S., Hrzenjak, A., Holzer, M., Dirnberger, S., Wadsack, C., Scharnagl, H., Stojakovic, T., Heinemann, A., and Oettl, K. 2009. Plasma-Advanced Oxidation Protein Products Are Potent High-Density Lipoprotein Receptor Antagonists In Vivo. Circ Res 104(6): 750-757. 
Martin, T., Alquier, T., Asakura, K., Furukawa, N., Preitner, F., and Kahn, B. 2006. Dietinduced Obesity Alters AMP Kinase Activity in Hypothalamus and Skeletal Muscle. J. Biol. Chem. 281(28): 18933-18941.

Milagro, F., Campion, J., and Martinez, J. 2006. Weight gain induced by high fat feeding involves increased liver oxidative stress. Obesity 14: 1118-1123.

Moreira, E., Fagundes, R., Filho, D., Neves, D., Sell, F., Bellisle, F., and Kupek, E. 2005. Effects of diet energy level and tomato powder consumption on antioxidant status in rats. Clin Nutr 24(6): 1038-1046.

Mori, Y., Ohyanagi, M., Koida, S., Ueda, A., Ishiko, K., and Iwasaki, T. 2006. Effects of Endothelium-Derived Hyperpolarizing Factor and Nitric Oxide on Endothelial Function in Femoral Resistance Arteries of Spontaneously Hypertensive Rats. Hypertens Res 29: 187-195.

Nadal, P., Canela, N., Katakis, I., and O'Sullivan, C.,K. 2011. Extraction, isolation, and characterization of globulin proteins from Lupinus albus. J Agric Food Chem. 59: $2752-2758$.

Nadeem, S., Raj, C., and Raj, N. 2012. The influence of Alpinia calcarata extract on the serum lipid and leptin levels of rats with hyperlipidemia induced by high-fat diet. AAPS J 2(3): 1822-1826. 
Ngo, D.H., Qian, Z.J., Ryu, B., Park, J.W., and Kim, S.K. 2010. In vitro antioxidant activity of a peptide isolated from Nile tilapia (Oreochromis niloticus) scale gelatin in free radical-mediated oxidative systems. Journal of Functional Foods 2(2): 107-117.

Nielsen, M., S., Karlsson, A., O., and Engelsen, S., B. 2008. Cereal (1 $\rightarrow 3,1 \rightarrow 4)-\beta$-Dglucans functional properties and molecular interactions. Annul transaction of the nordic rheology society $\mathbf{1 6 .}$

Ninfali, P., Gennari, L., Biagiotti, E., Cangi, F., Mattoli, L., and Maidecchi, A. 2009. Improvement in botanical standardization of commercial freeze-dried herbal extracts by using the combination of antioxidant capacity and constituent marker concentrations. Journal of AOAC International 92(3): 797-805.

Pandey, K.,B. and Rizvi, S.,I. 2009. Plant polyphenols as dietary antioxidants in human health and disease. Oxid Med Cell Longev 2(5): 270-278.

Parrado, J., Miramontes, E., Jover, M., Gutierrez, J.,F., Terán, L.,C., and Bautista, J. 2006. Preparation of a rice bran enzymatic extract with potential use as functional food. Food Chem 98(4): 742-748.

Passamonti, S., Vrhovsek, U., Vanzo, A., and Mattivi, F. 2005. Fast access of some grape pigments to the brain. J Agric Food Chem 53(18): 7029-7034.

Pérez-Jiménez, J. and Saura-Calixto, F. 2005. Literature data may underestimate the actual antioxidant capacity of cereals. J Agric Food Chem 53(12): 5036-5040.

Peterson, D.,M. 2001. Oat Antioxidants. J. Cereal Sci. 33(2): 115-129. 
Peterson, D.,M., Hahn, M.,J., and Emmons, C.,L. 2002. Oat avenanthramides exhibit antioxidant activities in vitro. Food Chem 79: 473-478.

Pierce, G.,B., Parchment, R.,E., and Lewellyn, A.,L. 1991. Hydrogen peroxide as a mediator of programmed cell death in the blastocyst. Differentiation 46(3): 181-186.

Poli, G., Leonarduzzi, G., Biasi, F., and Chiarpotto, E. 2004. Oxidative stress and cell signalling. Curr. Med. Chem 11(9): 1163-1182.

Pownall, T.L., Udenigwe, C.C., and Aluko, R. 2010. Amino acid composition and antioxidant properties of pea seed (Pisum sativum L.) enzymatic protein hydrolysate fractions. J A gric Food Chem 58(8): 4712-4718.

Prior, R., Gu, L., Wu, X., Jacob, R., Sotoudeh, G., Kader, A., and Cook, R. 2007. Plasma antioxidant capacity changes following a meal as a measure of the ability of a food to alter in vivo antioxidant status. Journal of the American College of Nutrition 26(2): 170-181.

Prior, R., Wu, X., and Schaich, K. 2005. Standardized Methods for the Determination of Antioxidant Capacity and Phenolics in Foods and Dietary Supplements. Journal of Agricultural and Food Chemistry 53(10): 4290-4302.

Pryor, W.,A.. 2000. Vitamin E and heart disease:: Basic science to clinical intervention trials. Free Radical Biology and Medicine 28(1): 141-164. 
Qureshi, A.,A., Burger, W.,C., Peterson, D.,M., and Elson, C.,E. 1986. The structure of an inhibitor of cholesterol biosynthesis isolated from barley. J Biol Chem 261(23): 10544-10550.

Rajapakse, N., Mendis, E., Byun, H.,G, and Kim, S.,K. 2005. Purification and in vitro antioxidative effects of giant squid muscle peptides on free radical-mediated oxidative systems. J Nutr Biochem 16(9): 562-569.

Reddy, B.,S. 1999. Prevention of colon carcinogenesis by components of dietary fiber. Anticancer Res 19(5A): 3681-3683.

Reeves, P.,G. 1997. Components of the AIN-93 Diets as Improvements in the AIN-76A Diet. ASNS 127(5): 8385-8415.

Remko, M., Fitz, D., Broer, R., and Rode, B.,M. 2011. Effect of metal Ions (Ni2+, Cu2+ and $\mathrm{Zn} 2+)$ and water coordination on the structure of L-phenylalanine, L-tyrosine, Ltryptophan and their zwitterionic forms. J Mol Model 17(12): 3117-3128.

Reyna-Villasmil, N., Bermúdez-Pirela, V., Mengual-Moreno, E., Arias, N., Cano-Ponce, C., Leal-Gonzalez, E., Souki, A., Inglett, G.,E., Israili, Z.,H., Hernández-Hernández, R., Valasco, M., and Arraiz, N. 2007. Oat-derived beta-glucan significantly improves HDLC and diminishes LDLC and non-HDL cholesterol in overweight individuals with mild hypercholesterolemia. Am J Ther 14(2): 203-212. 
Rice-Evans, C.A., Miller, N.J., Bolwell, P.G., Bramley, P.M., and Pridham, J.B. 1995. Therelative antioxidant activities of plant-derived polyphenolic flavonoids. Free Radical Res Com 22: 375-384.

Rival, S.G., Fornaroli, S., Boeriu, C.,G., and Wichers, H.,J. 2001. Caseins and casein hydrolysates. 1. lipoxygenase inhibitory properties. J Agric Food Chem 49(1): 287294.

Rokutan, K., Johnston, R.J., and Kawai, K. 1994. Oxidative stress induces S-thiolation of specific proteins in cultured gastric mucosal cells. American Journal of Physiology 266: $247-254$.

Rossmeisl, M., Rim, J.,S., Koza, R.,A., and Kozak, L.,P. 2003. Variation in type 2 diabetes-related traits in mouse strains susceptible to diet-induced obesity. Diabetes 52: 1958-1966.

Ryan, D., Kendall, M., and Robards, K. 2007. Bioactivity of oats as it relates to cardiovascular disease. Nutrition Research Reviews 20: 147-162.

Saiga, A., Tanabe, S., and Nishimura, T. 2003. Antioxidant activity of peptides obtained from porcine myofibrillar proteins by protease treatment. J A gric Food Chem 51(12): 3661-3667.

Saiki, R., Okazaki, M., Iwai, S., Kumai, T., Kobayashi, S., and Oguchi, K. 2007. Effects of pioglitazone on increases in visceral fat accumulation and oxidative stress in 
spontaneously hypertensive hyperlipidemic rats fed a high-fat diet and sucrose solution. Journal of Pharmacological Sciences 105(2): 157-167.

Sakanaka, S., Tachibana, Y., Ishihara, N., and Juneja, L.,R. 2004. Antioxidant activity of egg-yolk protein hydrolysates in a linoleic acid oxidation system. Food Chem 86(1): 99-103.

Satué-Gracia, M.,T., Frankel, E.,N., Rangavajhyala, N., and German, J.,B. 2000. Lactoferrin in infant formulas: effect on oxidation. J Agric Food Chem 48(10): 49844990.

Seidell, J., Muller, D., Sorkin, J., and Andres, R. 1992. Fasting respiratory exchange ratio and resting metabolic rate as predictors of weight gain: the Baltimore Longitudinal Study on Aging. Int. J. Obes. 16(9): 667-674.

Sereewatthanawut, I., Prapintip, S., Watchiraruji, K., Goto, M., Sasaki, M., and Shotipruk, A. 2008. Extraction of protein and amino acids from deoiled rice bran by subcritical water hydrolysis. Bioresour Technol 99: 555-561.

Sheih, I.C., Wu, T.K., and Fang, T.J. 2009. Antioxidant properties of a new antioxidativepeptide from algae protein waste hydrolysate in different oxidation systems. BioresourceTechnology 100(13): 3419-3425.

Sierra, M., García, J.,J., Fernández, N., Diez, M.,J., and Calle, A.,P. 2002. Therapeutic effects of psyllium in type 2 diabetic patients. Eur J Clin Nutr 56(9): 830-842. 
Silva,P,F,N., Brouwers, J.,F., and Gadella, B.,M. 2006. Chapter 1: Oxidative stress and fertility - aspects of molecular oxidation and their effects on the mammalian reproductive output. In Edited by Anonymous . pp. 1-68.

Siong, H.,T., Rodney, J., M., Christopher, L., B., and Samson, O., A. 2011. Canola Proteins for Human Consumption: Extraction, Profile, and Functional Properties. J Food Sci. 76(1): R16-R28.

Smith, J.C., Lang, D., McEneny, J., Evans, L.M., Scanlon, M., Young, I., and Davies, J. 2002. Effect of GH on lipid peroxidation and neutrophil superoxide Anion generating capacity in hypopituitary adults with GH deficiency. Clin. Endocrinol. (Oxf) 56(4): $449-455$.

Spitz, D., Elwell, J., Sun, Y., Oberley, L., Oberley, T., Sullivan, S., and Roberts, R. 1989. Oxygen toxicity in control and $\mathrm{H} 2 \mathrm{O} 2$-resistant Chinese hamster fibroblast cell lines. Arch Biochem Biophys 279(2): 249-260.

Suetsuna, K., Ukeda, H., and Ochi, H. 2000. Isolation and characterizationof free radical scavengingactivities peptides derived from casein. J Nutr Biochem 11(3): 128-131.

Suetsuna, k. and Chen, R.,J. 2002. Isolation and Characterization of Peptides with Antioxidant Activity Derived from Wheat Gluten. Food Sci Technol Res 8(3): 227230. 
Takahashi, M., Ikemoto, S., and Ezaki, O. 1999. Effect of the fat/carbohydrate ratio in the diet on obesity and oral glucose tolerance in C57BL/6J mice. J. Nutr. Sci. Vitaminol. 45(5): 583-593.

Tang, S., Hettiarachchy, N.S., Eswaranandam, S., and Crandall, P. 2003. Protein extraction from heat-stabilized defatted rice bran: II. The role of amylase, celluclast, and viscozyme. J Food Sci 68(2): 471-475.

Thompson, J., Manore, M., and Sheeshka, J. Nutrition A functional Approach, Third Edition. In Edited by Jones and Bartlett. Sudbury, Massachuetts.

Trumbo, P., Schlicker, S., Yates, A.,A., Poos, M., Food and Nutrition Board of the Institute of Medicine., and The National Academies. 2002. Dietary reference intakes: energy, carbohydrates, fiber, fat, fatty acids, cholesterol, protein, and amino acids. J Am Diet Assoc 102(11): 1621-1630.

Tsopmo, A., Diehl-Jones, B.,W., Aluko, R.,E., Kitts, D.,D., Elisia, I., and Friel, J.,K. 2009. Tryptophan released from mother's milk has antioxidant properties. Pediatr Res 66(6): 614-618.

Tucker, L.,A. and Thomas, K.,S. 2009. Increasing Total Fiber Intake Reduces Risk of Weight and Fat Gains in Women. J Nutr 139(3): 576-581.

Tzeng, Y.,M., Diosady, L.,L., and Rubin, L.,J. 1990. Production of canola protein materials by alkaline extraction, precipitation, and membrane processing. J Food Sci 55(4): 1147-1151. 
Udenigwe, C.,C. and Aluko, R.,E. 2011. Chemometric Analysis of the Amino Acid Requirements of Antioxidant Food Protein Hydrolysates. Int J Mol Sci 12(5): 31483161.

Uttara, B., Singh, A.,V., Zamboni, P., and Mahajan, R.,T. 2009. Oxidative Stress and Neurodegenerative Diseases: A Review of Upstream and Downstream Antioxidant Therapeutic Options. Curr Neuropharmacol 7(1): 65-74.

Valko, M., Leibfritz, D., Moncol, J., Cronin, M.T.D., Mazur, M., and Telser, J. 2007. Free radicals and antioxidants in normal physiological functions and human disease. Int. J. Biochem. Cell Biol. 39(1): 44-84.

Victor, Y.W., Kenneth, R.,S., Cluskey, J.E., and Inglett, G.E. 1977. Protein isolate from high-protein oats: preparation, composition and properties. J Food Sci 42(5): 13831386.

Wang, J., Cao, Y., Wang, C., and Sun, B. 2011. Wheat bran xylooligosaccharides improve blood lipid metabolism and antioxidant status in rats fed a high-fat diet. Carbohydr Polym 86: 1192-1197.

Wang, M., Hettiarachchy, N.,S., Qi, M., Burks, W., and Siebenmorgen, T. 1999a. Preparation and functional properties of rice bran protein isolate. J Agric Food Chem 47(2): 411-416. 
Wang, M., Hettiarachchy, N.S., Qi, M., Burks, A.W., and Siebenmorgen, T. 1999b. Preparation and functional properties of rice bran protein isolate. J A gric Food Chem 47(2): 411-416.

Wang, W. and De Mejia, E. 2005. A new frontier in soy bioactive peptides that may prevent age-related chronic diseases. CRFSFS 4(4): 63-78.

Welch, R.,M. 2005. Biotechnology, biofortification, and global health. 26(4): 419-421.

Welch, R.,W. 1995. Oats in human nutrition and health. World Crop Series : 433-479.

Witko-Sarsat, V., Friedlander, M., Capeillère-Blandin, C., Nguyen-Khoa, T., Nguyen, A.,T., Zingraff, J., Jungers, P., and Descamps-Latscha, B. 1996. Advanced oxidation protein products as a novel marker of oxidative stress in uremia. kidney international 49(5): 1304-13.

Witko-Sarsat, V., Friedlander, M., Nguyen, K., T., Capeillere-Blandin, C., Nguyen, A.,T., Canteloup, S., Dayer, J.,M., Jungers, P., Drueke, T., and Descamps-Latscha, B. 1998. Advanced oxidation protein products as novel mediators of inflammation and monocyte activation in chronic renal failure. J Immunol 161: 2524-2532.

Wolff, S.P. 1994. Ferrous ion oxidation in presence of xylenol orange for measurement of hydroperoxides. Methods in enzymology 233: 182-189.

Wood, P.J. 2007. Cereal $\beta$-glucans in diet and health. J. Cereal Sci. 46(3): 230-238. 
Wu, J. and Ding, X. 2002. Characterization of inhibition and stability of soy-proteinderived angiotensin I-converting enzyme inhibitory peptides. Food Res. Int. 35(4): $367-375$.

Wu, J. and Muir, A.,D. 2008. Comparative structural, emulsifying, and biological properties of 2 major canola proteins, cruciferin and napin. J Food Sci 73(3): C210C216.

Xiao, H., Xie, G., Wang, J., Hou, X., Wang, X., Wu, W., and Liu, X. 2013. Chicoric acid prevents obesity by attenuating hepatic steatosis, inflammation and oxidative stress in high-fat diet-fed mice. Food Res. Int. 54(1): 345-353.

Xu, X., Katayama, S., and Mine, Y. 2007. Antioxidant activity of tryptic digests of hen egg yolk phosvitin. J. Sci. Food Agr. 87(14): 2604-2608.

Yamaguchi, F., Saito, M., Ariga, T., Yoshimura, Y., and Nakazawa, H. 2000. Free radical scavenging activity and antiulcer activity of garcinol from garcinia indica fruit rind. $\mathrm{J}$ A gric Food Chem 48(6): 2320-2325.

Yang, Y., Zhang, S., Howe, K., Wilson, D.B., Moser,F,I,D., and Thannhauser, T.W. 2007. A Comparison of nLC-ESI-MS/MS and nLC-MALDI-MS/MS for GeLC-based protein identification and iTRAQ-based shotgun quantitative Proteomics. JBT 18(4): 226-237.

Youngs, V.,L. 1972. Protein Distribution in the Oat Kernel. Cereal Chem 49: 407 - 411. 
Yu, G.,C., LV, J., He, H., Huang, W., and Han, Y. 2012. Hepatoprotective effects of corn peptides against carbon tetrachloride induced liver injury mice. Food Biochem 36(4): $458-464$.

Zaidi, S.,M. and Banu, N. 2004. Antioxidant potential of vitamins A, E and C in modulating oxidative stress in rat brain. Clin Chim Acta 340(1): 229-233.

Zhu, K., Zhou, H., and Qian, H. 2006a. Antioxidant and free radical-scavenging activities of wheat germ protein hydrolysates (WGPH) prepared with alcalase. Process Biochem 41(6): 1296-1302.

Zhu, K., Zhou, H., and Qian, H. 2006b. Antioxidant and free radical-scavenging activities of wheat germ protein hydrolysates (WGPH) prepared with alcalase. Process Biochemistry 41(6): 1296-1302.

Zulueta, A., Esteve, M., and Frígola, A. 2009a. ORAC and TEAC assays comparison to measure the antioxidant capacity of food products. Food Chem 114: 310-316. 